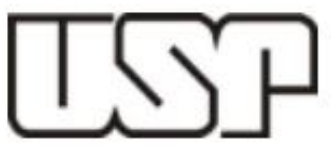

Universidade de São Paulo

Faculdade de Saúde Pública

Comissão de Pós-Graduação

RUBENS AMARAL FERREIRA FILHO

\title{
MUDANÇAS CLIMÁTICAS E O ACESSO À ÁGUA E ESGOTAMENTO SANITÁRIO - DESAFIOS E OPORTUNIDADES PARA OS ESTADOS DO CEARÁ E SÃO PAULO, BRASIL
}


RUBENS AMARAL FERREIRA FILHO

Mudanças Climáticas e o Acesso à água e Esgotamento Sanitário - Desafios e Oportunidades para os Estados do Ceará e São Paulo, Brasil

Dissertação apresentada ao Programa de PósGraduação Ambiente, Saúde e Sustentabilidade, da Faculdade de Saúde Pública, da Universidade de São Paulo, para a obtenção do título de Mestre em Ciências.

Orientadora: Dra. Gabriela Marques di Giulio

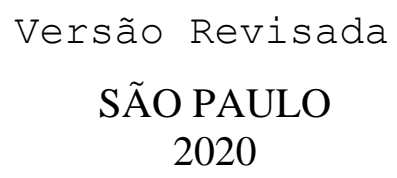


É expressamente proibido a comercialização deste documento, tanto na sua forma impressa como eletrônica. Sua reprodução total ou parcial, é permitida exclusivamente para fins acadêmicos e científicos, desde que na reprodução figure a identificação do autor, título, instituições e ano de dissertação.

\section{Catalogação na Publicação (CIP)}

Biblioteca/CIR da FSP/USP

Faculdade de Saúde Pública da Universidade de São Paulo

Ferreira Filho, Rubens Amaral

Mudanças Climáticas e o Acesso à água e Esgotamento Sanitário - Desafios e Oportunidades para os Estados do Ceará e São Paulo, Brasil. Prof ${ }^{a}$. Dr ${ }^{a}$. Gabriela Marques Di Giulio - São Paulo - 2020

$\mathrm{N}^{\mathrm{o}}$ fls. 153 f.: il.

Dissertação (Mestrado) - Universidade de São Paulo, 2020 
FERREIRA FILHO, Rubens Amaral, Mudanças Climáticas e o Acesso à Água e Esgotamento Sanitário - Desafios e Oportunidades para os Estados do Ceará e São Paulo, Brasil - Faculdade de Saúde Pública da Universidade de São Paulo, São Paulo, 2020 


\section{FOLHA DE APROVAÇÃO (DISSERTAÇÃO)}

FERREIRA FILHO, Rubens Amaral

Mudanças Climáticas e o Acesso à Água e Esgotamento Sanitário - Desafios e Oportunidades para os Estados do Ceará e São Paulo, Brasil.

Dissertação apresentada ao Programa de Pós Graduação Ambiente, Saúde e Sustentabilidade, da Faculdade de Saúde Pública, da Universidade de São Paulo, para obtenção do título de Mestre em Ciências.

Aprovado em:

\section{BANCA EXAMINADORA}

Prof $^{a}$. Dra. Gabriela de Marques di Giulio

Instituição: Universidade de São Paulo

Prof. Dr. Tadeu Fabrício Malheiros

Instituição: Universidade de São Paulo

Prof. Dr. Roger Rodrigues Torres

Instituição: Universidade Federal de Itajubá

Dr. Michelle Dalla Fontana

Instituição: Universidade de São Paulo 


\section{DEDICATÓRIA}

Parece ironia do destino, ao passo que escrevo esta dedicatória, cientistas do mundo todo são demandados para combater uma pandemia. Não vejo outra maneira de dedicar este trabalho a todos(as) que acreditam na ciência e a enxerga como aliada para nossas vidas, mesmo diante de um mundo que, cada vez mais, desacredita do poder do conhecimento e da seriedade do trabalho de profissionais que tanto dedicam suas vidas. 


\section{AGRADECIMENTOS}

Eu agradeço à Faculdade de Saúde Pública por me proporcionar uma nova fase da minha vida, por me apresentar Professores(as) e colegas que certamente levarei para vida toda. Os dois anos nesta Instituição, sem dúvidas, me trouxeram novas perspectivas. Meus agradecimentos se estendem para a Professora Dra. Gabriela Marques Di Giulio por orientar um jornalista pela primeira vez e acreditar no tema e me ajudar muito com os direcionamentos em que esta dissertação tomou. Também não posso deixar de agradecer ao Professor Dr. Leandro Giatti, um amigo de saneamento básico, sempre solícito e que me apresentou à Professora Gabriela quando eu contei meus planos acadêmicos. Ainda no âmbito da Universidade, meus sinceros agradecimentos ao Professor Dr. Roger Torres, da Universidade Federal de Itajubá, que, gentilmente, me ajudou na busca pelos dados climáticos do Ceará e São Paulo para esta dissertação, mesmo em dezembro, com festas a todo vapor. Obrigado, Professores!

Este segundo parágrafo separo para agradecer aqueles que estão comigo no dia a dia, aos meus amigos do Instituto Trata Brasil, que me deram força para eu conciliar o trabalho com a vida acadêmica. Um obrigado especial ao Édison Carlos, antes de tudo, um grande amigo que a vida me deu, por ser um líder que me incentivou a ir atrás deste Mestrado e por fazer acordos com horários de trabalho, além de auxiliar na publicação de parte dos dados desta dissertação como capítulo de um estudo do Instituto Trata Brasil.

Um agradecimento mais do que especial e eterno à minha esposa, Priscila, a primeira Mestre da família, com reconhecimento absurdo pelo trabalho incansável à língua inglesa; Priscila é a inspiração para muitos alunos(as), familiares e foi/é para mim. Sem dúvidas, ela foi minha co-orientadora não oficial.

Por fim, não menos importante, meus agradecimentos se estendem para meus familiares que, mesmo à distância, me incentivaram e entenderam meu distanciamento (ainda não era por causa do Covid-19). Obrigado mãe, pai e irmão. E obrigado aos meus avós. Os ambientes construídos por todos vocês até hoje são, pra mim, fundamentais em tudo. 


\section{RESUMO}

FERrEIRA FILHO, R. A. Mudanças Climáticas e o Acesso à Água e Esgotamento Sanitário - Desafios e Oportunidades para os Estados do Ceará e São Paulo, Brasil.

2020. 153 f. Dissertação (Mestrado) - Faculdade de Saúde Pública, Universidade de São

Paulo, São Paulo, 2020.

O acesso ao saneamento básico no Brasil sempre passou por desafios, e principalmente o acesso ao esgotamento sanitário teve uma evolução tímida em todas as regiões do país, diferentemente do acesso ao abastecimento de água. Dados do Sistema Nacional de Informações sobre Saneamento (SNIS, 2019) apontam que 46,85\% da população brasileira não é atendida com esgotamento sanitário e 16,38\% não têm acesso à rede de água. Dentro do contexto de infraestrutura urbana, saneamento básico é visto como um dos principais desafios perante as mudanças climáticas, sobretudo quanto aos recursos hídricos. Eventos extremos, como períodos longos de seca severa e chuvas extremas, estão cada vez mais presentes no cenário brasileiro, colocando em discussão a resiliência da infraestrutura e sua capacidade de adaptação frente aos riscos iminentes à saúde humana e ao ambiente. Considerando que o Brasil é signatário dos Objetivos do Desenvolvimento Sustentável - ODS, que contemplam tópicos de água e saneamento (ODS 6) e mudanças climáticas (ODS 13), discute-se nesta dissertação a necessidade do setor de saneamento básico incorporar a agenda das mudanças climáticas, com foco no abastecimento de água para consumo humano e na resiliência das infraestruturas de esgotamento sanitário. Os resultados obtidos por meio de análises documentais, revisão bibliográfica e entrevistas semiestruturadas com atores envolvidos com o saneamento básico nos estados do Ceará e São Paulo, realizadas entre abril a dezembro de 2019, evidenciam que o setor de saneamento básico ainda compreende as mudanças climáticas a partir dos eventos extremos climáticos vivenciados mais recentemente, isto é, as secas prolongadas da década de 2010, sem incorporar efetivamente, em suas decisões, perspectivas dos cenários futuros sobre os efeitos do aumento das temperaturas e aumento ou decréscimo de chuvas. Os impactos para a sociedade, ao observar as alterações climáticas e a inserção desta agenda para o setor de saneamento, são abordados discursivamente nos documentos e entrevistas analisados a partir, sobretudo, dos efeitos monetários, com aumentos de tarifa para consumo humano de água também atrelados à recuperação dos investimentos realizados para garantir segurança hídrica e resiliência das infraestruturas.

Palavras-chave: saneamento básico, mudanças climáticas, adaptação, São Paulo, Ceará. 


\section{ABSTRACT}

FERREIRA FILHO, R. A. Climate Change and Access to Water and Sanitation Challenges and Opportunities for the States of Ceara and Sao Paulo, Brazil. 2020. 153 p.

Dissertation (Master) - Faculty of Public Health, University of São Paulo, São Paulo, 2020.

Water and Sanitation in Brazil have always been a challenge, and mainly access to sewage disposals have evolved timidly in all regions of the country, unlike access to potable water supply. Data from the National Sanitation Information System (SNIS, 2019) show that $46.85 \%$ of the Brazilian population do not have access to sewage disposals and $16.38 \%$ do not have access to the potable water supply. Within the context of urban infrastructure, water and sanitation are one of the main challenges in the face of climate change, especially regarding water resources. Extreme climate events, such as long periods of severe drought and extreme rains, are increasingly present in the Brazilian scenario, in which the resilience of the infrastructure and the ability to adapt to the imminent risks to human health and the environment are at stake. Considering that Brazil is a signatory to the Sustainable Development Goals - SDGs, which include topics on water and sanitation (SDG 6) and climate change (SDG 13), this dissertation discusses the need for the water and sanitation sector to incorporate the agenda of climate changes with a focus on water supply for human consumption and the resilience of sewage infrastructure. The results obtained through documentary analysis, bibliographic review and semi-structured interviews with actors involved in water and sanitation in Ceara and Sao Paulo, from April to December 2019, show that the water and sanitation sector still perceives climate change from the most recent extreme climate events, that is, the extended droughts of the decade of 2010, without presenting perspectives of future scenarios on the effects of rising temperatures and increasing or decreasing rainfall. The impacts for society, when observing climate change and the insertion of this agenda for the water and sanitation sector through the documents and interviews, are demonstrated considering the monetary effects, with revenues increases for human consumption of water also linked to the recovery of investments made to guarantee water security and infrastructure resilience. The recommendations and final considerations about the themes worked on in the dissertation are added to a technical study carried out by Instituto Trata Brasil on water demand for the future.

Keywords: sanitation, climate change, adaptation, Sao Paulo, Ceara. 


\section{LISTAS DE SIGLAS E ABREVIATURAS}

ABCON - Associação Brasileira das Concessionárias Privadas de Serviços Públicos de Água e Esgoto

ACFor - Autarquia de Regulação, Fiscalização e Controle dos Serviços Públicos de Saneamento Ambiental

ANA - Agência Nacional das Águas

APRECE - Associação dos Municípios do Estado do Ceará

ARCE - Agência Reguladora de Serviços Públicos Delegados do Estado do Ceará

ARSESP - Agência Reguladora de Saneamento e Energia do Estado de São Paulo

BOVESPA - Bolsas de Valores de São Paulo

CAGECE - Companhia de Água e Esgoto do Ceará

CEMADEN - Centro Nacional de Monitoramento e Alertas de Desastres Naturais

CESBs - Companhias Estaduais de Saneamento Básico

CETESB - Companhia Ambiental do Estado de São Paulo

$\mathrm{CH}_{4}$ - Gás metano

CIM - Comitê Interministerial sobre Mudanças do Clima

$\mathrm{CO}_{2}$ - Dióxido de carbono

CONESAN - Conselho Estadual de Saneamento Básico

CNPq - Conselho Nacional de Desenvolvimento Científico e Tecnológico

COP - Conferência das Partes

DAEE - Departamento de Água e Energia Elétrica

DNOCS - Departamento Nacional de Obras Contra as Secas

ETA - Estação de Tratamento de Água

ETE - Estação de Tratamento de Esgoto

FEHIDRO - Fundo Estadual de Recursos Hídricos 
FETRAECE - Federação dos Trabalhadores da Agricultura do Ceará

FUNCEME - Fundação Cearense de Meteorologia e Recursos Hídricos

GCF - Documento-base para discussão da Estratégia do Brasil para o Fundo Verde do Clima

GEE - Gases de Efeito Estufa

IBGE - Instituto Brasileiro de Geografia e Estatística

IDH - Índice de Desenvolvimento Humano

IOCS - Inspetoria de Obras Contra as Secas]

IPCC - Painel Intergovernamental sobre Mudanças Climáticas

ITB - Instituto Trata Brasil

LDNSB - Lei de Diretrizes Nacional do Saneamento

KfW - Banco Alemão de Desenvolvimento

MC - Mudanças Climáticas

MCTI - Ministério da Ciência, Tecnologia e Inovação

MDR - Ministério do Desenvolvimento Regional

MMA - Ministério do Meio Ambiente

NYSE - Bolsa de Valores de Nova Iorque

ODS - Objetivos do Desenvolvimento Sustentável

OFWAT - Regulador Econômico do Setor de Água da Inglaterra e País de Gales

ONG - Organização Não-Governamental

ONU - Organização das Nações Unidas

PBMC - Painel Brasileiro de Mudanças Climáticas

PLANASA - Plano Nacional de Saneamento

PLANERH - Sistema de Gestão de Recursos Hídricos

PLANSAB - Plano Nacional de Saneamento Básico

PEMC - Política Estadual de Mudanças Climáticas 
PMSB - Plano Municipal de Saneamento Básico

PNA - Plano Nacional de Mudanças Climáticas

PNMC - Política Nacional de Mudanças Climáticas

RAN1 - Primeiro Relatório de Avaliação Nacional

SABESP - Companhia de Saneamento Básico do Estado de São Paulo

SISAR - Sistemas Integrados de Saneamento Rural do Ceará

SNIS - Sistema Nacional de Informações sobre Saneamento

SOHIDRA - Superintendência de Obras Hidráulicas

SUDENE - Superintendência de Desenvolvimento do Nordeste

UNFCCC - United Nations Framework Convention on Climate Change (UNFCCC) 


\section{LISTA DE ILUSTRAÇÕES}

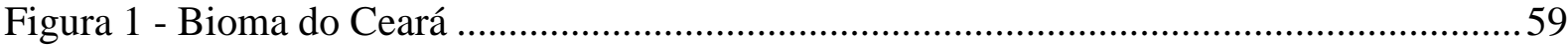

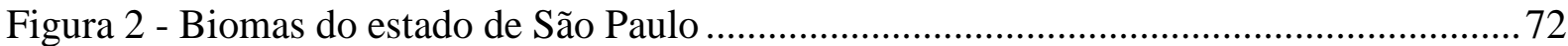

Figura 3 - Figura do estado de São Paulo com decrementos 2017-2018 ressaltados ...............73 


\section{LISTA DE QUADROS}

Quadro 1 - Entrevistados do setor de saneamento básico do Ceará e São Paulo...................... 30

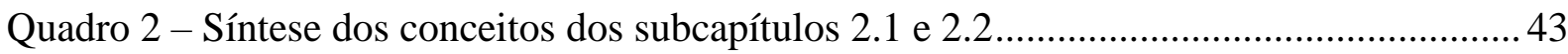

Quadro 3 - Evento extremo relacionado à seca no estado do Ceará ....................................... 63

Quadro 4 - Projeções climáticas para o estado do Ceará ........................................................ 65

Quadro 5 - Evento extremo relacionado à seca no estado de São Paulo ................................. 77

Quadro 6 - Projeções climáticas para o estado de São Paulo ................................................ 79

Quadro 7 - Achados nos Relatórios de Sustentabilidade e Relatório de Gestão da Cagece .... 88

Quadro 8 - Achados nos Relatórios de Sustentabilidade da Sabesp ....................................... 92

Quadro 9 - Percepções dos entrevistados sobre as mudanças climáticas ................................ 96

Quadro 10 - Percepções dos entrevistados sobre os impactos das mudanças climáticas em

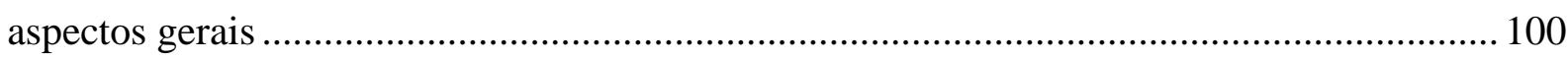

Quadro 11 - Percepções dos entrevistados sobre os impactos das mudanças climáticas ao setor de abastecimento de água e esgotamento sanitário ............................................................ 103 Quadro 12 - Percepções dos entrevistados sobre o valor da água sob a ótica dos impactos causados pelas mudanças climáticas

Quadro 13 - Percepções dos entrevistados sobre a ineficiência do setor de saneamento básico considerando as mudanças climáticas 112

Quadro 14 - Intersecções entre os Relatórios de Sustentabilidade (ou Relatório de Gestão) e as entrevistas realizadas. 


\section{LISTA DE GRÁFICOS}

Gráfico 1 - Série histórica de variações do clima .................................................................. 64

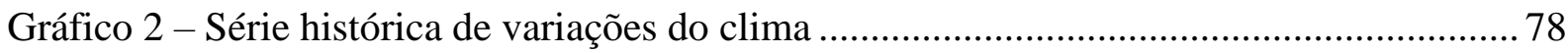

\section{LISTA DE TABELAS}

Tabela 1 - Atendimentos totais de água (população com acesso); de esgoto referido aos municípios atendidos com água (população com acesso ao esgoto); e investimentos realizados em água e esgotamento sanitário (BRASIL, 2018; BRASIL, 2017; BRASIL, 2016; BRASIL, 2015; BRASIL, 2014; BRASIL, 2013; BRASIL 2012; BRASIL 2011) ................................ 46

Tabela 2 - Adaptado - População e taxa anual de crescimento do Estado do Ceará (IBGE, 2019) 56

Tabela 3 - Projeção de População e taxa anual de crescimento do Estado do Ceará (IBGE, 2019)

Tabela 4 - Investimentos realizados e indicadores de acesso ao abastecimento de água e esgotamento sanitário pelo estado do Ceará de 2011 a 2018 (BRASIL, 2018; BRASIL, 2017; BRASIL, 2016; BRASIL, 2015; BRASIL, 2014; BRASIL, 2013; BRASIL 2012; BRASIL 2011)

Tabela 5 - População e taxa anual de crescimento do Estado de São Paulo (IBGE, 2019) ..... 69 Tabela 6 - Adaptado - Projeção de População e taxa anual de crescimento do Estado de São Paulo (IBGE, 2019)

Tabela 7 - Investimentos realizados e indicadores de acesso ao abastecimento de água e esgotamento sanitário pelo estado de São Paulo de 2011 a 2018 (BRASIL, 2018; BRASIL, 2017; BRASIL, 2016; BRASIL, 2015; BRASIL, 2014; BRASIL, 2013; BRASIL 2012; BRASIL 2011) 


\section{SUMÁRIO}

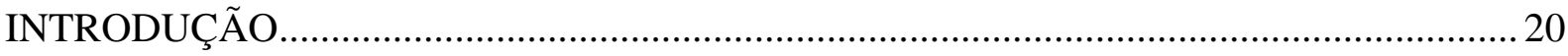

CAPÍTULO 1 - PROCESSOS METODOLÓGICOS ............................................................ 25

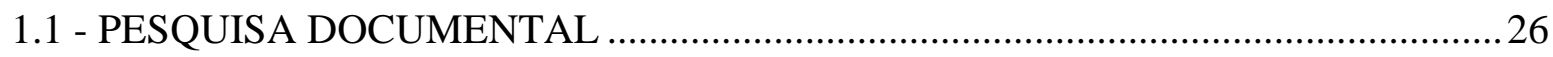

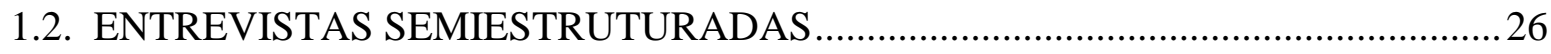

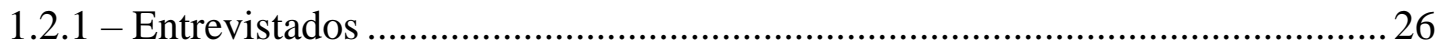

1.2.2 - Processo de realização das entrevistas .............................................................. 29

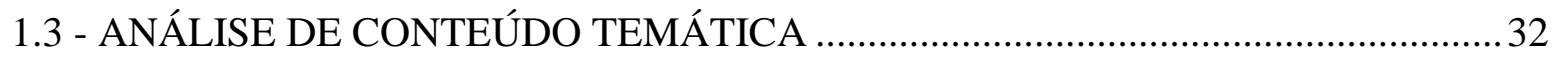

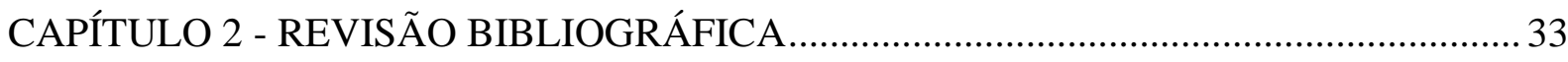

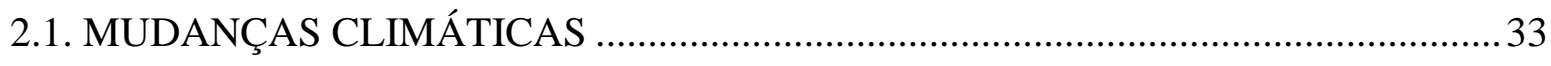

2.1.1 - Mitigação e Adaptação no Contexto Global .................................................... 33

2.1.2 - Mitigação e Adaptação no Contexto Brasileiro ............................................... 37

2.2 EVENTOS EXTREMOS CLIMÁTICOS - PERCEPÇÕES E RISCOS ........................ 40

2.3 - CONTEXTOS DO SANEAMENTO BÁSICO .................................................... 44

2.3.1 - Serviços de água e esgoto e a relação com as mudanças climáticas .............. 47

2.4 - MUDANÇAS CLIMÁTICAS E SANEAMENTO BÁSICO EM OUTROS PAÍSES52

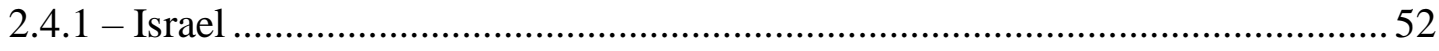

2.4.2 - Inglaterra e País de Gales ............................................................................ 53

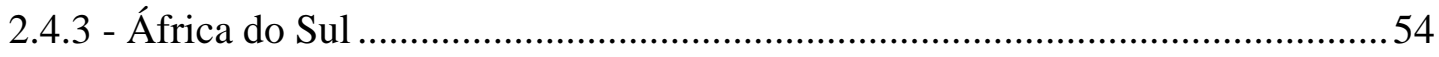

CAPÍTULO 3 - CONTEXTO DA PESQUISA - CEARÁ E SÃO PAULO .......................... 56

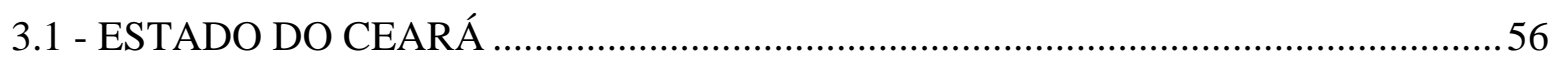

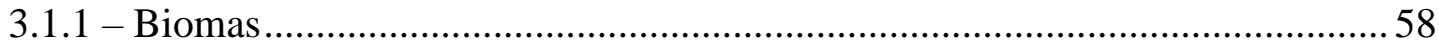

3.1.2 Políticas de Recursos Hídricos e Mudanças Climáticas...................................... 60

3.1.3. Evento extremo climático - seca de 2012 a 2018 .......................................... 62

3.1.4 - As Mudanças Climáticas e o setor de Saneamento no Ceará.......................... 66

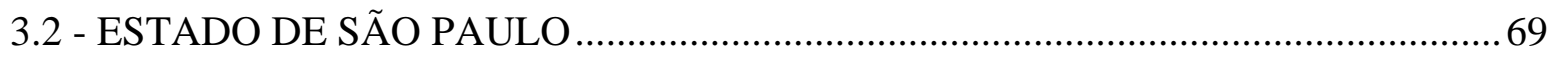

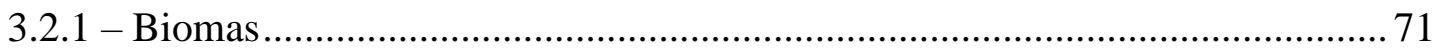

3.2.2 - Políticas de Recursos Hídricos e Mudanças Climáticas ................................ 73

3.2.3 - Evento extremo climático - Seca de 2013-2015 _.......................................... 75

3.2.4 - Mudanças climáticas e o setor de Saneamento de São Paulo......................... 79

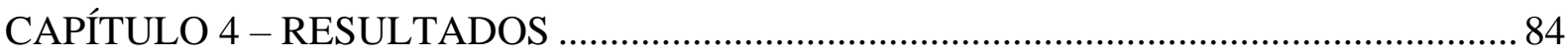


4.1 - RELATÓRIOS DE SUSTENTABILIDADE E DE GESTÃO DE 2012 A 2018 -

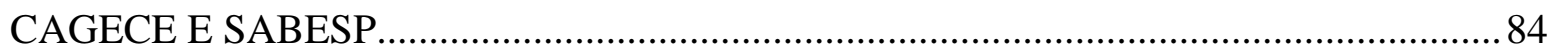

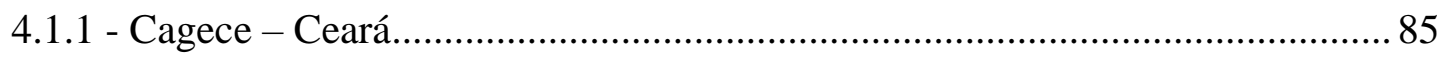

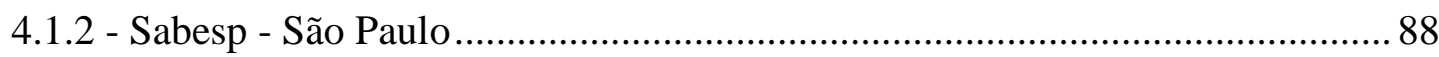

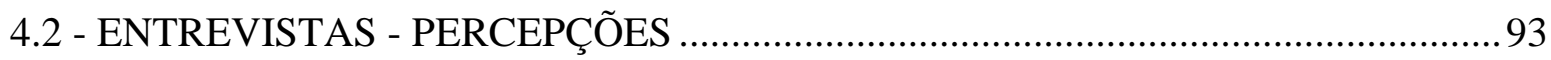

4.2.1 - Mudanças Climáticas ................................................................................... 93

4.2.2 - Riscos dos impactos das mudanças climáticas ................................................ 98

4.2.3 - Riscos dos impactos das mudanças climáticas ao setor de saneamento .......101

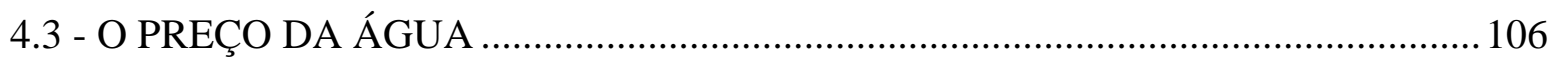

4.4 - INEFICIÊNCIA NA GESTÃO DO SANEAMENTO BÁSICO ……………..............110

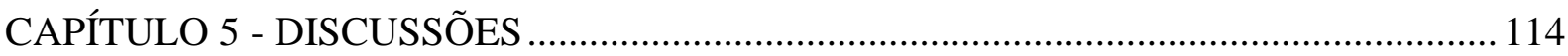

CAPÍTULO 6 - CONSIDERAÇÕES FINAIS (LIMITAÇÕES E SUGESTÕES PARA

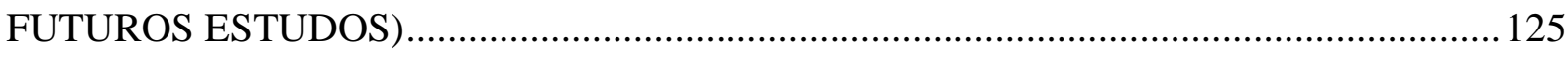

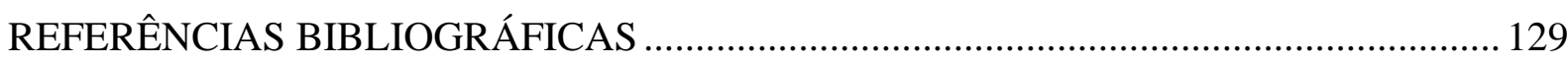

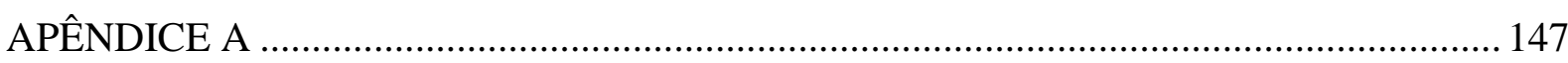

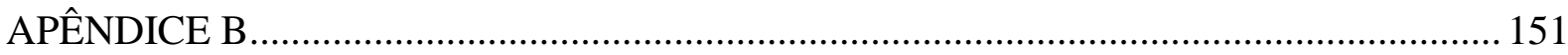




\section{APRESENTAÇÃO}

Quando ingressei na faculdade de Comunicação Social com habilitação em Jornalismo na Universidade de Taubaté (SP), em 2009, jamais passou pela minha cabeça que eu estaria tão envolvido com temas ambientais e sociais 10 anos depois. Não que minha escolha em jornalismo não vislumbrasse atuações em prol da sociedade, mas talvez eu me enxergasse atrás de uma bancada com terno e gravata noticiando os principais fatos de um local, ou mesmo na rua cobrindo fatos diversos que também assolam a sociedade. $\mathrm{O}$ jornalismo me proporcionara quatro anos com atuação dentro de órgãos públicos no interior de São Paulo (Pindamonhangaba), mais diretamente nas assessorias de imprensa no legislativo e executivo. Coincidentemente, ao fazer recordações daqueles tempos, vêm à memória minhas participações, mesmo que tímidas, na construção de agendas ambientais, e participando como ouvinte de debates sobre provimento de saneamento rural para áreas rurais do interior paulista. Anos mais tarde, mais precisamente em 2013, vivi a mudança mais drástica, ao mudar para a capital, São Paulo, e perceber que o Brasil tem deficiências mais peculiares do que eu imaginava. Foi a partir da oportunidade de me juntar ao Instituto Trata Brasil (ITB), que os temas ambientais ganharam mais vida para mim. Conheci histórias de pessoas que nasceram e cresceram sem saber o que é ter água tratada, e que consideram normal conviver com as águas negras (esgoto) na porta de casa. Ouvi de senhores e senhoras idosos(as) que diarreia, dengue e outras doenças são comuns no dia a dia das comunidades, em decorrência da ausência de saneamento básico. Em São Paulo, eu ainda não precisei vestir terno e gravata com microfone na mão para exercer meu papel de jornalista; esta oportunidade que me foi dada de estar à frente da Comunicação do ITB me proporcionou mais do que eu imaginava todos os dias eu estou diante de problemas crônicos nos municípios brasileiros ao que concerne saneamento básico e saúde pública, tentando transmitir isso para o maior número de jornalistas, formadores de opiniões e outros profissionais, para que eles possam replicar nos meios de comunicação de massa.

Em 2017, ou antes, eu entrei em contato com a Prof ${ }^{a}$. Gabriela Marques Di Giulio, também jornalista de formação e doutora em Ambiente e Sociedade, docente da Faculdade de Saúde Pública da Universidade de São Paulo; este contato inicial foi para entender como eu poderia envolver a comunicação de risco com o saneamento básico em um futuro estudo acadêmico, afinal, as externalidades negativas associadas à ausência da infraestrutura hídrica e de esgotamento sanitário ganham repercussões cada vez mais no cenário brasileiro, com os 
desafios impostos pela urbanização e pela deficiência histórica deste setor da infraestrutura no país. Este contato me proporcionou olhares mais aprofundados sobre outro desafio para a sociedade global, e não diferente, para a brasileira: as mudanças climáticas.

A partir da junção de ideias e minha inquietação em relação aos acontecimentos no Ceará e São Paulo com as secas de 2012 a 2018, e 2013 a 2015, respectivamente, e considerando minha atuação como profissional de comunicação de saneamento básico, o item "comunicação risco" foi aproveitado de outra maneira, usando as mudanças climáticas e o saneamento básico como instrumentos de análises para trazer à tona problemas estruturais que as secas nos mostraram. A escassez hídrica, o aumento na conta do consumidor, o risco de contaminações das águas pelo armazenamento inadequado da população, a ausência de cobertura de esgotamento sanitário como fator de risco à saúde humana, entre outros, foram imprescindíveis para que esta construção da dissertação resultasse nos capítulos seguintes.

Desta forma, utilizando ainda um pouco da construção de elementos da Comunicação Social que me fizeram chegar até este Mestrado, os próximos capítulos são contribuições para mais uma etapa de estudos sobre os efeitos das mudanças climáticas pela academia. 


\section{INTRODUÇÃO}

Estar preparado para o que vai ocorrer, independentemente de quais perspectivas ou atividades, requer uma capacidade de intervenção da qual não se trata de convencimento, como STENGERS (2015) descreve, e sim de como transmitir e sob quais enfoques para aqueles a quem isso pode afetar. À medida que temos um mundo em constante transformação, certamente as mudanças climáticas - e as consequências das mesmas - tornam-se desafios urgentes a serem enfrentados para os quais devemos buscar métodos adaptativos e de mitigação (ARTAXO, 2019). Ao considerar as cidades do século XXI, os desafios das mudanças climáticas se somam aos desafios de algumas vertentes do saneamento básico ${ }^{1}$, problemas estes ainda não resolvidos para a sociedade brasileira (FERREIRA et al., 2017). Com concentrações demográficas mais latentes e desafios urbanos constantes, a ausência ou inadequação da infraestrutura de abastecimento de água e esgotamento sanitário nas cidades brasileiras potencializa mais riscos à população.

A literatura aponta que os principais impactos negativos da ausência de água tratada e coleta e tratamento de esgoto para a sociedade estão diretamente associados à saúde humana. No país, $16,38 \%$ de brasileiros ainda não têm acesso ao abastecimento de água por redes e 46,85\% não têm acesso às redes de esgoto (SNIS, 2019), portanto, há milhões de brasileiros ainda vivendo sem acesso à infraestrutura básica sanitária, que potencializa as vulnerabilidades causadas pelos eventos extremos climáticos (YANG et al., 2017). Esta ausência dos serviços básicos vai de encontro às medidas non-regrets, capazes de reduzir a vulnerabilidade de sistemas urbanos aos impactos das mudanças climáticas estão atreladas ao saneamento básico (OBERMAIER et al., 2011). Os indicadores de mortalidade infantil e de internações por doenças diarreicas evidenciam como estes serviços são fatores de relevância para a qualidade de vida e manutenção de saúde dos indivíduos (SILVA, 2017).

Em meio às dificuldades econômicas, os recentes indicadores de investimentos neste setor não avançam; ao mesmo tempo, as alterações do clima trazem novos desafios do ponto de vista de investimentos e prioridades (AMBRIZZI et al., 2012). Na literatura sobre as questões climáticas, é possível identificar um consenso científico de que haverá aumento de temperatura em $1,5^{\circ} \mathrm{C}$ para as próximas décadas, colocando o país como uma das nações mais

\footnotetext{
${ }^{1} \mathrm{Na}$ Lei 11.445/2007, o termo 'saneamento básico' se refere a: a) abastecimento de água potável; b) esgotamento sanitário; c) limpeza urbana e manejo de resíduos sólidos; e d) drenagem e manejo das águas pluviais. Esta dissertação foca no abastecimento de água e esgotamento sanitário.
} 
vulneráveis às alterações do clima (MARENGO, 2007; AMBRIZZI et al., 2012), pois exibe áreas propícias à seca extensiva ou chuvas intensas em períodos curtos. A seca do Sudeste de 2013 a 2015, o período de estiagem na região Amazônica em 2005 e $2010^{2}$ e a constante seca no Nordeste evidenciam que o país tem enfrentado impactos relacionados aos eventos extremos climáticos ano após ano. NOBRE et al. (2010) ressaltam que as regiões do Brasil tendem a ter mais desafios relacionados à escassez de água nos próximos anos, o que impõe a necessidade de repensar como garantir acesso à água de forma equitativa - e que arranjos são necessários em termos de infraestrutura urbana. De acordo com o Atlas de Abastecimento Urbano de Água da Agência Nacional de Águas - ANA (2010), de 2005 a 2025, as demandas médias para abastecimento de água urbano no Brasil projetam um acréscimo de $28 \%$, ainda sem considerar os efeitos das mudanças climáticas.

Neste contexto, abrem-se discussões sobre como a infraestrutura urbana, sobretudo o acesso à água e esgotamento sanitário, precisa se adaptar para ofertar melhores serviços para a população e estar preparada para danos maiores (SIEGEL, 2017). Entre os relatórios oficiais que balizam os desafios brasileiros para as próximas décadas, destacam-se o Fundo Verde para o Clima - GCF (2017) e o Primeiro Relatório de Avaliação Nacional (RAN1) do Painel Brasileiro de Mudanças Climáticas (2015), nos quais se observam apontamentos similares para o Brasil: aumento na temperatura, variações de precipitação, risco de abastecimento hídrico, aumento do nível do mar e mudanças nos padrões climáticos como alguns dos principais impactos já identificados.

MARENGO et al. (2016) teorizam que as mudanças climáticas não acontecem de forma linear pelo mundo, mas de maneira localizada. É possível observar que alguns países desenvolvidos e outros em desenvolvimento já estão incorporando ações de adaptação em níveis locais por instrumentos de políticas públicas com foco nas consequências que os eventos extremos climáticos podem trazer para a sustentabilidade de um local (SMITH, 2015). Adaptar-se aos processos de alterações do clima pode também evitar danos previstos pelas atividades humanas, assim como trazer novas oportunidades para os espaços urbanos (MARENGO et al., 2016). No entanto, o processo adaptativo das mudanças climáticas no Brasil parece seguir o mesmo ritmo do avanço ao acesso aos serviços de água e esgoto: ainda é lento e crítico, impactado, particularmente, por questões associadas ao desenvolvimento e à desigualdade (DI GIULIO et al., 2016).

\footnotetext{
${ }^{2}$ http://g1.globo.com/natureza/noticia/2011/08/amazonia-enfrentou-em-2010-maior-seca-da-historia-dizestudos-do-inpe.html acessado em 10 de junho de 2020
} 
Ainda dentro da perspectiva de adaptação, a pesquisa realizada busca responder o questionamento sobre se, e como, as discussões e projeções sobre mudanças climáticas estão sendo incorporadas no processo operacional do setor de saneamento básico, bem como na regulação dos serviços. Dado os desafios do saneamento básico no Brasil, sobretudo aos serviços de esgotamento sanitário, a poluição causada aos corpos hídricos devido à ausência de coleta e tratamento de esgoto também se soma ao estresse hídrico associado à oferta e demanda, agravando-se mais intensamente nos períodos de secas prolongadas, já previstas pelos climatologistas e vivenciados pelos estados brasileiros, como os casos do Ceará (20122018) e São Paulo (2013-2015). Estudos apontam que as temperaturas dos estados do Ceará e São Paulo, assim como todo o território brasileiro, tem aumentado significativamente, principalmente nas últimas três décadas, assim como há também indícios de alterações nos regimes de chuva nesses estados (AMBRIZZI et al., 2012). Estes acréscimos de temperatura ao longo dos anos, juntamente com alterações no regime de chuvas, podem contribuir para o processo de desertificação do semiárido brasileiro, em que se encontra o Ceará, que tende a sofrer com estiagens mais severas até o fim do século (MORO et a., 2015), e também a tornar mais frequentes os episódios de seca e consequente crise hídrica na região Sudeste, como aquela enfrentada nos anos de 2013 a 2015 (MARENGO 2015).

Ademais, ambos estados possuem diferenças em atendimento de água e esgotamento sanitário. Mais de 3,6 milhões de pessoas no Ceará ainda não são abastecidas com água e mais de 6,5 milhões não possuem atendimento de coleta de esgoto; em São Paulo, o número de pessoas sem acesso à água é de 1,7 milhão, enquanto sem acesso a atendimento de coleta de esgoto beira mais de 4,6 milhões de pessoas (SNIS, 2019; PAINEL SANEAMENTO BRASIL, 2020). Ainda com as deficiências apontadas, Ceará e São Paulo são os dois primeiros estados brasileiros a trabalharem com políticas estaduais de Recursos Hídricos e Saneamento, sendo o primeiro desde 1992, por meio do Sistema Integrado de Gestão dos Recursos Hídricos, e o segundo a partir de 1991, por meio da criação da própria Política Estadual de Recursos Hídricos. Tais políticas serviram como base para as políticas e instrumentos de outras Unidades da Federação posteriormente (MALHEIROS et al., 2013; COUTINHO, 2010).

O pioneirismo de ambos e os cenários de saneamento e climáticos que apresentam sinalizam discussões necessárias para que os investimentos em água não estejam atrelados somente ao aumento da oferta de água bruta por meio de interligação de reservatórios ou transposições de rios como respostas adaptativas às mudanças do clima. Grandes obras dependentes do ciclo hidrológico - a chamada infraestrutura cinza de saneamento - tendem a 
ser mais suscetíveis aos impactos de extremos climáticos, colocando em risco o abastecimento hídrico para consumo humano (OATES et al., 2014). Por outro lado, é preciso persistir no provimento do esgotamento sanitário adequado para a população para que as doenças de veiculação hídrica não se propaguem com mais facilidade como resultados dos efeitos climáticos (LEONETI et al., 2011). Ao ofertar esses serviços para a população, ou oferecer alternativas individuais, criam-se oportunidades de utilizar o reúso de água como fonte de abastecimento humano e para agricultura, sobretudo em tempos de escassez (SIEGEL, 2017). Surgem, assim, discussões também sobre processos de dessalinização da água do mar como fonte alternativa de água, principalmente em grandes centros próximos às áreas litorâneas (GUERREIRO, 2009).

Considerando os impactos das mudanças climáticas na sociedade, sob a ótica da infraestrutura urbana, esta dissertação tem como objetivos centrais (1) investigar como as intervenções na infraestrutura de acesso ao abastecimento de água e esgotamento sanitário nos estados do Ceará (CE) e São Paulo (SP) têm sido planejadas em consonância com os cenários climáticos - particularmente considerando-se que a ocorrência dos eventos extremos climáticos pode se dar de diversas maneiras; (2) compreender as percepções de atores sociais que atuam no setor de saneamento básico acerca das mudanças climáticas e dos possíveis riscos para o setor de água e esgoto.

A partir de análise de conteúdo de documentos, realização de entrevistas e revisão de literatura, a presente dissertação busca, assim, contribuir para a discussão sobre o planejamento do saneamento básico considerando as mudanças climáticas como um dos riscos para a sociedade e também para a resiliência das infraestruturas. Para tanto, se debruça sobre estudos e análises em duas Unidades da Federação do Brasil (CE e SP) que vivenciaram eventos extremos climáticos semelhantes na década de 2010 (seca prolongada), mas que possuem características socioeconômicas distintas, com diferenças também no processo de planejamento do saneamento básico. Os resultados alcançados são discutidos à luz dos conceitos apresentados na revisão bibliográfica sobre processos adaptativos e de mitigação às mudanças climáticas e confrontados, a partir dos documentos analisados e das narrativas dos entrevistados (representantes das companhias estaduais de saneamento básico, agências reguladoras e de Organizações Não-Governamentais), numa perspectiva de compreender como a agenda climática tem sido incorporada no processo operacional do setor de saneamento nos dois estados. Os resultados evidenciam quais efeitos negativos e positivos a absorção da pauta das mudanças climáticas pode ter sobre o consumidor e os sistemas. 
A pesquisa desenvolvida entre 2018 e 2020 foi elaborada no âmbito do Programa de Pós-graduação Ambiente, Saúde e Sustentabilidade (Mestrado Profissional) da Faculdade de Saúde Pública da Universidade de São Paulo. Como Produto Técnico exigido pelo Programa de Mestrado Profissional, parte dos resultados discutidos nesta dissertação integrará também um relatório a ser publicado pelo Instituto Trata Brasil sobre a disponibilidade hídrica para o futuro no Brasil e as oportunidades que o saneamento básico pode gerar. Para além desta Introdução, a dissertação apresentada está estruturada em sete capítulos, incluindo: Capítulo 1 - Processos Metodológicos; Capítulo 2 - Revisão Bibliográfica: Mudanças Climáticas e Saneamento Básico; Capítulo 3 - Contextos da Pesquisa - Ceará e São Paulo; Capítulo 4 Resultados; Capítulo 5 - Discussões; Capítulo 6 - Considerações Finais e Recomendações. 


\section{CAPÍTULO 1 - PROCESSOS METODOLÓGICOS}

A escolha por compreender os aspectos de São Paulo e Ceará em termos climáticos e de saneamento básico (água e esgoto), e não outras Unidades da Federação, se dá i) pelas estratégias pioneiras no setor hídrico e de saneamento de ambos os estados que sustentam até mesmo a formulação da Política Nacional de Recursos Hídricos (MALHEIROS, 2013; SCANTIMBURGO, 2013); ii) por São Paulo ser a primeira Unidade da Federação a ter um Programa Estadual de Mudança Climáticas Globais ${ }^{3}$, em 1995, e também ter a primeira Política Estadual de Saneamento Básico, em 19924; iii) por Ceará ser a Unidade da Federação que incorporou a convivência com a seca no Plano Estadual de Recursos Hídricos, em 1992, quando foi o segundo estado do país a entrar em vigência, após São Paulo; e iv) pelo fato de que enfrentaram eventos extremos climáticos relacionados à seca na década de 2010 (Ceará de 2012 a 2018; São Paulo de 2013 a 2015). Cabe ressaltar ainda que as duas Unidades da Federação possuem companhias de saneamento básico com características distintas: enquanto a Sabesp é uma empresa mista, com ações nas Bolsas de Valores de São Paulo e Nova Iorque, a Cagece é uma companhia de quase $90 \%$ de domínio estatal, com protocolo de prospecto preliminar de IPO (oferta pública inicial de ações), para que tenha ações na Bolsa de Valores ${ }^{5}$.

Por se tratar de uma pesquisa qualitativa e exploratória, o estudo serviu-se de: a) revisão bibliográfica de conceitos que permeiam os objetos de interesse da pesquisa (a saber: mudanças climáticas em um contexto histórico; aspectos adaptativos e de mitigação em contexto global e brasileiro; eventos climáticos extremos; percepções e riscos); b) levantamento sobre os contextos do saneamento básico; c) levantamento sobre os contextos dos estados de Ceará e São Paulo, buscando identificar as ações em relação às mudanças climáticas e o saneamento básico; d) pesquisa documental por meio de análise dos Relatórios de Sustentabilidade e Gestão das companhias estaduais de saneamento básico de 2012 a 2018; e) realização de entrevistas semiestruturadas com profissionais que trabalham em instituições de saneamento básico (operação e regulação), e representantes de ONGs que têm o saneamento básico e mudança climática como temas principais, realizadas de abril a dezembro de 2019.

\footnotetext{
${ }^{3}$ https://cetesb.sp.gov.br/proclima/wp-content/uploads/sites/36/2014/08/resolucao_sma_22.pdf acessado em 18 de maio de 2020

${ }^{4}$ https://www.al.sp.gov.br/norma/?id=18507 acessado em 18 de maio de 2020

5 https://valor.globo.com/financas/noticia/2019/12/17/companhia-de-saneamento-do-ceara-protocola-prospectopreliminar-de-ipo-1.ghtml acessado em 10 de fevereiro de 2020.
} 
A pesquisa não traça comparações entre os dois estados a partir dos achados nos relatórios de sustentabilidade ou entrevistas semiestruturadas; o objetivo central é apresentar e discutir panoramas, a partir dos resultados sobre como as intervenções na infraestrutura de acesso ao abastecimento de água e esgotamento sanitário têm sido planejadas considerando os cenários climáticos.

\section{1 - PESQUISA DOCUMENTAL}

Por meio de acesso à homepage oficial da empresa de saneamento básico que atua no Estado de São Paulo, a pesquisa documental envolveu análise dos relatórios de sustentabilidade disponíveis da Sabesp no período de 2012 a 2018. No caso da Cagece, o único relatório de sustentabilidade disponível na homepage da empresa data de 2017. Ao fazer solicitação, via e-mail, a empresa esclareceu que antes de 2017 não havia a prática de produzir relatórios de sustentabilidade. Informou ainda que o documento de 2018 ainda está em processo de finalização, não sendo possível, assim, disponibilizar uma cópia. As análises desses documentos permitiram compreender os posicionamentos das instituições em relação ao reconhecimento das mudanças climáticas como fator de risco para a operação dos serviços de água e esgoto nos dois estados.

A partir das recomendações de análise de conteúdo apontadas por Deacon et al. (1998), as questões norteadoras para a análise desse conjunto de documentos foram:

a) Como as mudanças climáticas aparecem nos documentos oficiais das instituições estudadas?

b) Quais os tratamentos dados pelas instituições às mudanças climáticas enquanto risco de negócio?

\subsection{ENTREVISTAS SEMIESTRUTURADAS}

\subsection{1 - Entrevistados}

A opção por realizar entrevistas semiestruturadas está diretamente relacionada ao objetivo principal do estudo: compreender as percepções de atores sociais que atuam no setor de saneamento básico acerca das mudanças climáticas e os possíveis riscos para o setor de água e esgoto. As entrevistas foram realizadas de abril a dezembro de 2019.

Assim, num primeiro momento, foram entrevistados representantes das Companhias Estaduais de Saneamento Básico do Ceará e São Paulo. De acordo com dados do Governo 
Federal de 2018, publicado em 2019 (Sistema Nacional de Informações sobre Saneamento - SNIS) ${ }^{6}$, cerca de $75 \%$ dos municípios brasileiros têm os serviços de água e esgotamento sanitário prestados por alguma empresa estadual. Em São Paulo, a Sabesp opera em mais da metade dos municípios paulistas (371 dos 645 municípios) ${ }^{7}$; no estado do Ceará, a empresa estadual, Cagece, opera em 152 dos 184 municípios $^{8}$. No caso especial do Ceará, foi selecionado também o Instituto Sisar, que trabalha junto à Cagece nas áreas rurais do estado no provimento de insumos, corpo técnico e materiais para o abastecimento de água potável $^{9}$. Como o Sisar não é uma diretoria da Cagece, mas sim uma Federação de Associações, entende-se que a presença da mesma na pesquisa se fez necessário considerando a configuração climática do estado do Ceará, em que a seca tem um papel relevante no contexto rural (SUASSUNA, 2002). Um representante do Instituto Sisar, enquanto instituição operadora do abastecimento de água nas zonas rurais cearenses, foi entrevistado com o objetivo de compreender como esta entidade relaciona o tema das mudanças climáticas com a operação de abastecimento de água para a população rural.

Foram realizadas também entrevistas com representantes das agências reguladoras dos estados do Ceará e São Paulo, com o objetivo de investigar suas percepções sobre a temática estudada, considerando a obrigatoriedade de, no Brasil, se constituir agências reguladoras, previsto na Lei de Diretrizes do Saneamento Básico (LDSNB), 11.445/2007, para que haja fiscalizações de contratos, tarifas, programas e planos das empresas concedentes (GALVÃO JUNIOR et al, 2008). Neste sentido, para o estado de São Paulo há a Arsesp - Agência Reguladora de Saneamento e Energia do Estado de São Paulo -, responsável por fiscalizar a operação dos serviços prestados pela Sabesp em boa parte do estado. De acordo com informações retiradas do próprio portal oficial da Arsesp, esta agência é "uma autarquia de regime especial, vinculada à secretaria Estadual de Governo, criada pela Lei Complementar 1.025/2007 e regulamentada pelo Decreto 52.455/2007’. No Ceará, a Agência Reguladora de Serviços Públicos Delegados do Estado do Ceará (Arce) é a responsável por fiscalizar a operação dos serviços prestados pela Cagece. A Arce "é uma autarquia especial, dotada de autonomia orçamentária, financeira, funcional e administrativa. Foi criada em 30 de dezembro de 1997, através da Lei n ${ }^{\circ} 12.786 "$.

\footnotetext{
${ }^{6}$ http://www.snis.gov.br/downloads/diagnosticos/ae/2018/Diagnostico_AE2018.zip acessado em 30 de junho de 2019

${ }^{7} \mathrm{http}: / /$ site.sabesp.com.br/site/interna/Default.aspx?secaoId=505 acessado em 25 de março de 2018

${ }^{8} \mathrm{https} / / / \mathrm{www} . c a g e c e . c o m . b r / q u e m-s o m o s / h i s t o r i a /$ acessado em 25 de março de 2018

${ }^{9}$ http://www.sisar.org.br/institucional/\#quem-somos acessado em 27 de agosto de 2019
} 
Por fim, foram realizadas entrevistas com representantes das ONGs EloAmigo/ASA (Ceará) e SOS Mata Atlântica (São Paulo), que possuem atividades com relação ao meio ambiente, água e esgotamento sanitário em ambos os estados. Estas organizações foram selecionadas devido às iniciativas das mesmas durante os momentos de secas prolongadas, sendo um braço da sociedade civil para a busca de transparência e mais fiscalização frente às decisões institucionais no âmbito do abastecimento de água e esgotamento sanitário (JACOBI et al., 2015).

Para todas as instituições envolvidas na pesquisa, a seleção dos(as) entrevistados(as) atendeu aos seguintes critérios: (i) relevância dos cargos ocupados no passado e/ou presente, sobretudo para cargos de tomadas de decisões, como presidentes, diretores e/ou superintendentes; (ii) disponibilidade e concordância para a concessão de entrevistas todos os entrevistados assinaram Termo de Consentimento Livre e Esclarecido, como exigência do Comitê de Ética em Pesquisa ${ }^{10}$.

Cabe destacar que, apesar das tentativas, não foi possível a realização de entrevistas com os presidentes atuais da Sabesp e Cagece (gestões de 2018-2019), já que ambos não responderam os pedidos feitos por e-mail e por telefone. Em São Paulo, o atual Secretário de Infraestrutura e Meio Ambiente (2018 - até o presente momento) também não se dispôs a conceder entrevista (recusa feita por meio de e-mail institucional). $\mathrm{O}$ mesmo ocorreu com o presidente da Companhia de Gestão de Recursos Hídricos do estado do Ceará (COGERH), que recusou conceder a entrevista por meio de mensagens encaminhadas por seu assessor via celular.

Como base para conduzir as entrevistas semiestruturadas, foram feitos questionamentos acerca da experiência profissional e acadêmica de cada entrevistado(a), como:

a) - Qual é a percepção do(a) entrevistado(a) sobre as mudanças climáticas? Como o(a) entrevistado(a) encara as ocorrências dos eventos extremos sob a ótica pessoal?

b) - Como o(a) entrevistado(a) vê a empresa/instituição pelo qual o(a) mesmo(a) trabalha em relação à concepção das mudanças climáticas? Existem pesquisas ou ações na empresa/instituição para compreender os impactos das mudanças climáticas?

\footnotetext{
${ }^{10}$ Número do Parecer da Plataforma Brasil como exigência do Comitê de Ética da Faculdade de Saúde Pública da Universidade de São Paulo: 3.315.556. Ver Apêndices A e B.
} 
c) - Como o(a) entrevistado(a) avalia a demanda futura por água para todos os setores, mas sobretudo para o abastecimento à população? É um risco a ser avaliado e considerado?

d) - Como o(a) entrevistado(a) enxerga os desafios para expandir redes de coleta de esgoto? As mudanças climáticas também são mais uma barreira para o avanço desta infraestrutura?

e) - $\mathrm{O}$ (a) entrevistado entende que há implicações de custos para a sociedade quando os eventos extremos atingem a infraestrutura de esgotamento sanitário?

Para além destas perguntas, foram feitas outras questões que constam no roteiro completo das entrevistas, disponível no Apêndice A desta dissertação.

\subsection{2 - Processo de realização das entrevistas}

As entrevistas com informantes do estado de São Paulo foram realizadas pessoalmente; já as entrevistas com informantes do Ceará foram conduzidas por telefone e Skype. Em todos os casos, a média de duração das entrevistas foi de 45 minutos e utilizou-se gravador para posterior transcrição na íntegra dos conteúdos. Adotou-se um roteiro de entrevistas (ver Apêndice A), com um conjunto de perguntas genéricas para todos os entrevistados, independentemente da ocupação e cargo profissional. Além das perguntas norteadoras, os entrevistados se sentiram à vontade para trazer suas experiências e outras conexões com os assuntos abordados (MOREIRA et., al, 2005), sem evadir dos temas propostos (BONI et. al, 2005). No Quadro 1 são identificados os entrevistados, preservando-se suas identidades pessoais. 
Quadro 1 - Entrevistados do setor de saneamento básico do Ceará e São Paulo

\begin{tabular}{|c|c|c|c|}
\hline ENTREVISTADO & REPRESENTANTE & FORMAÇÃO ACADÊMICA & $\begin{array}{c}\text { TEMPO DE } \\
\text { EMPRESA/ } \\
\text { INSTITUIÇÃO }\end{array}$ \\
\hline E1 & Presidente do Conselho de Administração da Cagece & $\begin{array}{c}\text { Engenheiro Civil / Mestre em } \\
\text { Saneamento }\end{array}$ & 16 anos \\
\hline E2 & Diretor de Negócios do Interior da Cagece & Químico Industrial & 38 anos \\
\hline E3 & Diretor de Engenharia da Cagece & Engenheiro Civil & 18 anos \\
\hline E4 & Diretor Presidente do Instituto Sisar & Ciências Contábeis & 15 anos \\
\hline E5 & $\begin{array}{c}\text { Presidente da Agência Reguladora do Estado do Ceará - } \\
\text { Arce }\end{array}$ & Advogado & 1 ano \\
\hline E6 & Ex-presidente da Sabesp & $\begin{array}{l}\text { Geógrafa e Mestre em } \\
\text { Administração Pública }\end{array}$ & 3 anos \\
\hline E7 & Ex-presidente da Sabesp & $\begin{array}{l}\text { Engenheiro Civil e Doutor em } \\
\text { Hidrologia e Recursos Hídricos }\end{array}$ & 3 anos \\
\hline E8 & Diretor Metropolitano da Sabesp & Engenheiro Civil & 38 anos \\
\hline E9 & Diretor de Sistemas Regionais da Sabesp & Engenheiro Civil & 2 anos \\
\hline E10 & $\begin{array}{c}\text { Diretor Presidente e Diretor de Regulação Técnica e } \\
\text { Fiscalização dos Serviços de Saneamento Básico da } \\
\text { Agência Reguladora de Saneamento e Energia do Estado } \\
\text { de São Paulo }\end{array}$ & $\begin{array}{c}\text { Engenheiro Sanitarista e Mestre em } \\
\text { Engenharia Sanitária }\end{array}$ & 4 anos \\
\hline
\end{tabular}




\begin{tabular}{|c|c|c|c|}
\hline \multirow{2}{*}{ ENTREVISTADO } & REPRESENTANTE & $\begin{array}{c}\text { TEMPO DE } \\
\text { EMPRESA/ } \\
\text { INSTITUIÇÃo }\end{array}$ \\
\hline E11 & Coordenador da ONG EloAmigo e Representante do & Administração ACADÊMICA \\
\hline E12 & $\begin{array}{c}\text { Córitas Ceará } \\
\text { Atlântica e representante do Aliança pela Água em São } \\
\text { Paulo }\end{array}$ & $\begin{array}{c}\text { Jornalista especialista em Políticas } \\
\text { Públicas }\end{array}$ \\
\hline
\end{tabular}

Fonte: Elaboração do autor 


\section{3 - ANÁLISE DE CONTEÚDO TEMÁTICA}

A partir da proposta de classificação e categorização de conteúdos proposta por CARLOMAGNO et al. (2016), a análise temática das transcrições das entrevistas resultou em unidades de significação, estabelecendo-se, assim, as seguintes categorias de análises:

A- Mudanças Climáticas e Percepção;

B- Riscos das Mudanças Climáticas e Percepção;

C- Riscos das Mudanças Climática para os serviços de abastecimento de Água e Esgotamento Sanitário

Da terceira categoria analítica, emergiram duas subcategorias (ou categorias mais específicas) focadas particularmente na questão de saneamento, a saber: a) preço da água; b) ineficiência da gestão das empresas de saneamento básico frente às mudanças do clima. 


\section{CAPÍTULO 2 - REVISÃO BIBLIOGRÁFICA}

O delineamento desta dissertação decorre da compreensão de conceitos, a partir de uma perspectiva interdisciplinar, atrelados às mudanças climáticas, como adaptação, mitigação, eventos extremos climáticos, riscos e percepções. Ao considerar que esta dissertação traça uma linha entre a internalização das mudanças climáticas na agenda do saneamento básico, faz-se necessário também compreender os contextos políticos e sociais que permeiam a pauta das mudanças climáticas pelo mundo e, sobretudo, no Brasil, como retratados neste capítulo.

\subsection{MUDANÇAS CLIMÁTICAS}

\subsection{1 - Mitigação e Adaptação no Contexto Global}

As alterações dos padrões de temperatura e precipitação são bases primordiais para estabelecer mecanismos de projeções e ações atrelados às mudanças climáticas (MC) em todo o mundo (MILHORANCE, 2019). PETIT (1999), ao trazer à tona as discussões climáticas durante os últimos quatro ciclos glaciais-interglaciais, evidencia como as variações climáticas na Terra e o ritmo dos processos de aquecimento e resfriamento ocorreram. Foram observadas variações de até $10^{\circ} \mathrm{C}$ nestes períodos, sendo que para dobrar a temperatura seriam necessários mais dez mil anos; já o resfriamento exigiria de 30 a 50 mil anos (RODRIGUES FILHO et al., 2016; NEDER, 2019). É sabido que as ações provocadas pela força do homem sobre a Terra vêm acelerando os processos de aquecimento, portanto, observa-se, há pelo menos 250 anos (com a Revolução Industrial), um aumento gradativo de até $1^{\circ} \mathrm{C}$ (RODRIGUES FILHO et al., 2016).

Considerando a velocidade observada quanto as alterações do clima, as análises globais sobre o tema ganharam repercussão com a criação do Painel Intergovernamental sobre Mudanças Climáticas - IPCC (Intergovernmental Panel on Climate Change), fundado em 1988, que reúne pesquisadores e revisores de várias partes do mundo com o intuito de analisarem a produção científica acerca de condições climáticas, impactos, riscos, projeções futuras e processos de adaptação e mitigação. O IPCC conta também com pesquisadores brasileiros que contribuem com análises sobre os efeitos das mudanças climáticas.

Os cenários climáticos desenvolvidos para os países derivam das projeções legitimadas pelo IPCC, com panoramas de avaliação climática para o futuro a partir de metodologias consolidadas (MARENGO et al., 2011). Além dos relatórios produzidos pelo IPCC, que sintetizam o estado da arte sobre as questões climáticas e reverberam nas agendas políticas 
dos países, é importante citar também a United Nations Framework Convention on Climate Change (UNFCCC - Convenção-Quadro das Nações Unidas sobre a Mudança do Clima, em português), criada na Eco-92 (Conferência das Nações Unidas sobre Meio Ambiente e Desenvolvimento), no Rio de Janeiro, em 1992 (OBERMAIER et al., 2013).

As discussões climáticas se intensificam, a partir de então, com as primeiras Conferências das Partes (COP) organizadas pela UNFCCC anualmente, cujos acordos são propostos para que os países adotem políticas e medidas à luz da adaptação e mitigação das mudanças climáticas (DE MORAIS, 2019; DI GIULIO et al., 2016). Importantes marcos são observados desde então, como (i) a criação do Protocolo de Quioto, em 1997, e efetivação do mesmo em 2005; (ii) proposições sobre vulnerabilidade e adaptação na COP-09 de 2003; (iii) a divulgação de meta para fixação de aquecimento de até $1,5^{\circ} \mathrm{C}$, com restrição até $2^{\circ} \mathrm{C}$ na COP-15, de 2009; (iv) a criação do Quadro de Adaptação de Cancun na COP-16, em 2010; a divulgação do $5^{\circ}$ Relatório de Avaliação (AR5) na COP-21, em Paris, França, em 2015, cuja conclusão principal foi consolidar as ações antrópicas como responsáveis pelas mudanças climáticas, além da assinatura do "Acordo de Paris", estabelecendo novas metas para 20 anos em relação à adaptação e mitigação.

No relatório especial do IPCC divulgado após a COP-21, intitulado de SR1.5 (IPCC, 2018), propõe-se reduzir o aquecimento a menos de $2^{\circ} \mathrm{C}$ dos níveis pré-industriais e continuar os esforços para limitar o aquecimento em até $1,5^{\circ} \mathrm{C}$ acima dos níveis pré-industriais. As observações já indicam um aumento de cerca de $0,87^{\circ} \mathrm{C}$ na temperatura média da superfície global entre 2006-2015, comparado à média de 1850-1900, tida como representativa do período pré-industrial.

No mesmo documento, a elevação do nível do mar é apontada como uma das principais consequências atreladas à elevação da temperatura média global, que tende a continuar além de 2100 , mesmo que o aquecimento global seja limitado a $1,5^{\circ} \mathrm{C}$ no século XXI; este aumento da temperatura média da superfície amplia a invasão de água salgada em infraestrutura de reservação de água para abastecimento público, inundações e danos à infraestrutura (IPCC, 2018). Limitando o aquecimento global a $1,5^{\circ} \mathrm{C}$ em comparação com $2^{\circ} \mathrm{C}$, projeta-se uma redução dos impactos nos ecossistemas envolvendo as áreas terrestres, água doce e áreas costeiras.

Ao considerar que a humanidade já está sofrendo as consequências do efeito do aquecimento provocado pelas ações antrópicas como as emissões de gases de efeito estufa (GEE), os conceitos de mitigação (combater as causas) e adaptação (preparar para o enfrentamento dos efeitos independentemente dos impactos - negativos ou positivos) são 
fundamentais no contexto das mudanças climáticas (RODRIGUES FILHO et al., 2016; IPCC, 2007).

$\mathrm{Na}$ agenda da mitigação, o segundo relatório do IPCC (AR2), divulgado em 1995, estabeleceu diretrizes para a criação do Protocolo de Quioto, que foi lançado dois anos mais tarde. Neste documento foi estabelecido que os países desenvolvidos deveriam criar instrumentos e desenvolver políticas para a redução dos GEE. Ao passar a ser vigorado em 2005, o Protocolo de Quioto estabeleceu um primeiro compromisso olhando uma perspectiva de quatro anos (2008 a 2012), impondo uma redução de 5,2\% ao considerar as emissões de GEE de 1990.

A agenda de respostas às mudanças climáticas preconizada pelo IPCC avalia cinco processos (NOBRE, 2010), sendo: (i) adaptação antecipatória, em que se observa de antemão os impactos provocados pelas mudanças climáticas; (ii) adaptação autônoma, estimulada pelas mudanças ecológicas naturais ou do próprio mercado baseada no bem-estar e sustentabilidade das pessoas; (iii) adaptação planejada, advinda de proposições e resultados de políticas deliberadas, reconhecendo a ocorrência de impactos das mudanças climáticas; (iv) capacidade de adaptação, voltada à capacidade de um sistema se ajustar à mudança climática, privilegiando oportunidades, ou enfrentando consequências; e (v) mitigação, intervenção proposta para reduzir os impactos das próprias forças do homem na natureza, como as diminuições da emissão de GEE. Quando se avaliam as adaptações no contexto climático, a duração dos processos adaptativos pode ser considerada de curto a longo prazo. Em curto prazo, são observados os impactos dos eventos extremos climáticos; no longo prazo, são focados os ajustes estruturais com base em probabilidades (SMIT et al., 2010; DE MORAIS, 2019).

Os relatórios do IPCC, ao tratarem de adaptação, estimulam os processos adaptativos do global para o local associando-os aos impactos climáticos observados pela comunidade científica com o aumento da temperatura média e mudança no ciclo hidrológico (AMBRIZI et al., 2014; SEARCHINGER et al., 2008). À medida que os relatórios científicos consideram que as mudanças climáticas não acontecem de forma linear pelo mundo, mas de maneira localizada, os acordos e tratados firmados pelos países têm expectativas de que a adaptação decorra por meio de instrumentos de políticas públicas em níveis locais, visando o desenvolvimento sustentável (SMITH, 2015; MARENGO et al. 2016). Ao considerar os inputs dos relatórios do IPCC sobre as medidas de adaptação e mitigação em relação ao aquecimento de $1,5^{\circ} \mathrm{C}$ a $2^{\circ} \mathrm{C}$, planejar políticas públicas para que as cidades se adaptem melhor à inevitável elevação da temperatura passa por reavaliar os modos de consumo e 
produção, bem como promover a equidade social, política e econômica (RODRIGUES FILHO et al., 2016; MORAIS, 2019).

EAKIN et al. (2014) também trazem duas perspectivas relevantes à adaptação dentro do processo às mudanças climáticas, particularmente nos ambientes urbanos: capacidades genéricas e capacidades específicas. A primeira tem um foco na capacidade de enfrentar e responder a problemas por meio de investimentos e ajustes em recursos básicos, tais como saúde, mobilidade, renda, saneamento básico, enquanto a segunda está centrada nos instrumentos necessários para o enfrentamento e respostas específicas às mudanças climáticas. Os conceitos de EAKIN são similares ao que BROWN (2011) também elucida sobre a adaptação sustentável, com foco nas classes mais vulneráveis com integração ambiental e equidade social, em que se procura estabelecer ambientes mais estáveis e resilientes (MORAIS, 2019). Contudo, o processo adaptativo nem sempre segue modelos sustentáveis, pela dificuldade de encontrar sinergia entre as mudanças climáticas e os impactos no desenvolvimento econômico. É nesta perspectiva, por exemplo, que DI GIULIO et al. (2019) apontam que os processos de adaptação são mais suscetíveis a adesão quando se juntam à integralidade de processos já existentes, mirando à sustentabilidade, qualidade de vida e resiliência das infraestruturas.

Outros autores entendem que os processos adaptativos são admitidos quando ocorre um (i) procedimento antecipatório, isto é, antecipando-se ao evento extremo; (ii) coetâneo, ou seja, durante o evento; ou (iii) responsivo, portanto, após aos eventos (BRYANT et al. 2000; DE MORAIS, 2019). Ainda que haja limitações para a compreensão dos fatores interferentes à adaptação, atribuindo a complexidade de medir capacidades adaptativas e sua eficácia (ENGLE, 2011), a agenda da adaptação tomou novos ares ao considerar a Agenda 2030 focada nos Objetivos do Desenvolvimento Sustentável (ODS) da Organização das Nações Unidas (ONU), estabelecendo, assim, processos adaptativos para poder público, refletindo no engajamento da sociedade civil e das empresas. Entre os 17 objetivos universais colocados aos países signatários, o ODS 13 propõe "tomar medidas urgentes para combater a mudança climática e seus impactos", estabelecendo cinco metas ${ }^{11}$ :

13.1 - Reforçar a resiliência e a capacidade de adaptação a riscos relacionados ao clima e às catástrofes naturais em todos os países;

13.2 Integrar medidas da mudança do clima nas políticas, estratégias e planejamentos nacionais;

\footnotetext{
${ }^{11}$ https://nacoesunidas.org/pos2015/ods13/ acessado em 18 de fevereiro de 2020
} 
13.3 Melhorar a educação, aumentar a conscientização e a capacidade humana e institucional sobre mitigação, adaptação, redução de impacto e alerta precoce da mudança do clima;

13.4 Implementar o compromisso assumido pelos países desenvolvidos partes da UNFCCC para a meta de mobilizar conjuntamente US\$ 100 bilhões por ano a partir de 2020, de todas as fontes, para atender às necessidades dos países em desenvolvimento, no contexto das ações de mitigação significativas e transparência na implementação; e operacionalizar plenamente o Fundo Verde para o Clima por meio de sua capitalização o mais cedo possível;

13.5 - Promover mecanismos para a criação de capacidades para o planejamento relacionado à mudança do clima e à gestão eficaz, nos países menos desenvolvidos, inclusive com foco em mulheres, jovens, comunidades locais e marginalizadas.

Por meio da integralidade promovida com as ações de adaptação e mitigação das mudanças climáticas, CAMPBELL et al. (2018) indicam que o ODS 13 busca criar práticas adaptativas aliando a outros objetivos, como Consumo e Produção Sustentável (ODS 12), Fome Zero e Agricultura Sustentável (ODS 2), Erradicação da Pobreza (ODS 1), Educação de Qualidade (ODS 4), Igualdade de Gênero (ODS 5), Água Potável e Saneamento (ODS 6), Vida Terrestre (ODS 15), e Energia Limpa e Acessível (ODS 7).

\subsection{2 - Mitigação e Adaptação no Contexto Brasileiro}

Com os importantes marcos relacionados à institucionalização da agenda climática na discussão entre os países, o Brasil assumiu três compromissos iniciais em consonância com a mitigação (RODRIGUES E FILHO et al., 2016), sendo eles: (i) inventário nacional de emissões de GEE; (ii) projetos de Mecanismo de Desenvolvimento Limpo (MDL); e (iii) mitigação das emissões pela redução do desmatamento e degradação florestal.

A agenda climática brasileira se intensificou em 1999 com a constituição da Comissão Interministerial de Mudança Global do Clima (CIMGC) presidida pelo Ministério de Ciência e Tecnologia (MCTI), no Decreto No 8.200; logo depois, em 2000, o país criou o primeiro Fórum Brasileiro de Mudanças Climáticas (FBMC); em 2004, foi lançado o documento "Comunicação Nacional Inicial do Brasil à Convenção-Quadro das Nações Unidas sobre Mudanças do Clima; em 2007, foi lançado o Comitê Interministerial sobre Mudanças do Climas (CIM), que subsidiou instrumentos relevantes para a elaboração do Plano Nacional de Mudanças Climáticas (PNA). Em 2009, o Brasil sancionou a Política 
Nacional de Mudanças Climática (PNMC) como um acordo voluntário junto à UNFCCC para redução de emissões de gases de efeito estufa, publicado na Lei $\mathrm{n}^{\circ} 12.187$. O Decreto $\mathrm{n}^{\circ}$ 7.390/2010 regulamentou a PNMC e estabeleceu uma redução entre 36,1\% e 38,9\% de GEE projetadas até 2020, o que significa diminuição entre 1.168 milhões de $\mathrm{tCO}_{2} \mathrm{eq}$ e 1.259 milhões de $\mathrm{tCO}_{2}$ eq (NEVES et al., 2015).

Além da redução de emissões de GEE, a PNMC fortaleceu a elaboração de planos setoriais relacionados à adaptação e mitigação (OBERMAIER et al., 2013), envolvendo os setores da: Agricultura, Biodiversidade e Ecossistemas, Cidades, Desastres Naturais, Indústria e Mineração, Infraestrutura (Energia, Transportes e Mobilidade Urbana), Povos e Populações Vulneráveis, Recursos Hídricos, Saúde, Segurança Alimentar e Nutricional e Zonas Costeiras). No mesmo ano, a Portaria Interministerial MCT/MMA n 356, de 25 de setembro de 2009, instituiu o Painel Brasileiro de Mudanças Climáticas (PBMC) inspirado no IPCC, com apoios do Governo Britânico via Department for International Development (DFID), o Conselho Nacional de Desenvolvimento Científico e Tecnológico (CNPq), Fundo Nacional sobre Mudança do Clima (Fundo Clima), Ministério da Ciência, Tecnologia e Inovação (MCTI), e Ministério do Meio Ambiente (MMA) ${ }^{12}$. A criação do PMBC sistematizou publicações de pesquisadores(as) brasileiros com o objetivo de fazer um panorama da situação do país em relação às mudanças climáticas, assim como criar projeções futuras (DUARTE, 2019).

O Primeiro Relatório de Avaliação Nacional sobre Mudanças Climáticas (RAN1) divulgado em 2013 está dividido em três volumes, sendo: 1. Base Científica da Mudança Climática; 2. Impactos, Vulnerabilidade e Adaptação; e 3. Mitigação. Entre as principais conclusões trazidas no relatório, destacam-se as projeções climáticas desenvolvidas para os seis biomas brasileiros que apontaram redução na precipitação para Amazônia, Caatinga, Cerrado e Pantanal; e aumento na precipitação nas regiões da Mata Atlântica e Pampa. Observou-se também elevação das temperaturas para todos os seis biomas, com destaque para a região do Cerrado com um aumento de $5^{\circ} \mathrm{C}$ a $5,5^{\circ} \mathrm{C}$ até 2100 (PMBCa, 2013).

Dois anos após a promulgação da PNMC, em 2011, o país deu novos passos ao criar o Centro Nacional de Monitoramento e Alertas de Desastres Naturais (CEMADEN), após as chuvas registradas naquele ano na região Serrana do Rio de Janeiro, culminando no pior desastre do Brasil, com quase 950 mortes e mais de 300 pessoas desaparecidas ${ }^{13}$. Ainda no mesmo ano, novamente o Brasil foi palco de discussões políticas sobre desenvolvimento

\footnotetext{
12 http://www.pbmc.coppe.ufrj.br/index.php/pt/organizacao/historia acessado em 18 de fevereiro de 2020

${ }^{13} \mathrm{https}: / /$ www.cemaden.gov.br/historico-da-criacao-do-cemaden/ acessado em 19 de fevereiro de 2020
} 
sustentável na Rio + 20, no Rio de Janeiro, tendo como objetivo um balanço das ações propostas há 20 anos.

Em 2015, o país promulgou outra Lei focada na mitigação, de $\mathrm{N}^{\circ} 13.153$, que institui a Política Nacional de Combate à Desertificação e Mitigação dos Efeitos da Seca; e a criação da Comissão Nacional de Combate à Desertificação. A Lei Federal, ao considerar a intensificação da seca em algumas regiões do país, propõe artigos relacionados à adaptação hídrica, como (i) instalações de cisternas para captação de água de chuvas, e barragens superficiais e subterrâneas, (ii) implantação de tecnologias para água de reúso na produção enviveirada de mudas para revegetação e reflorestamento, em zonas urbanas e rurais; entre outros pontos relacionados.

Em 2016, enfim, foi promulgado o Plano Nacional de Adaptação às Mudanças Climáticas, posicionando o Brasil junto a outros países que adotaram medidas internas de adaptação como política pública, e colocando os municípios e estados como atores importantes na contribuição para que o país criasse mecanismos de adaptação frente às alterações do clima (DI GIULIO et al., 2016).

Entre as participações do Brasil nas COPs sublinham-se os acordos anunciados em edições anteriores e, em particular, o acordo firmado na COP-21, em Paris, no qual o país sinalizou seu compromisso em extinguir o desmatamento ilegal até 2030, com restaurações de 12 milhões de hectares, recuperação de 15 milhões de hectares de pastagens degradadas e integração de 5 milhões de hectares de lavoura-pecuária-florestas (REI et al., 2017). Na COP23, em Bonn, na Alemanha, o Brasil foi eleito como "Fóssil do Dia" por mais de mil ONGs devido à tramitação da Medida Provisória 795 no Congresso brasileiro que garantiu subsídios ao setor de petróleo e gás em até R 1 trilhão para os próximos $20 \operatorname{anos}^{14}$. Na mesma edição, o país se candidatou a sediar a COP-25, que ocorreria no final de dezembro de 2019, o que não ocorreu após a decisão do Governo Federal eleito em 2018. Assim que a nova equipe assumiu o Poder Executivo, o Ministério do Meio Ambiente ensaiou também sair do "Acordo de Paris" firmado em 2015, colocando em risco as relações internacionais do país (AQUINO et al., 2019).

A reação do Brasil na COP-25, realizada em Madri, na Espanha, em dezembro de 2019, foi diferente das reuniões anteriores; o país criticou as medidas propostas dos países

\footnotetext{
14 https://www1.folha.uol.com.br/ambiente/2017/11/1935668-ganhador-dofossil-do-dia-na-cop-23-brasil-quer-
} hospedar-a-cop-25.shtml acessado em 18 de fevereiro de 2020 
desenvolvidos e atribuiu aos combustíveis fósseis o problema maior nas emissões de $\mathrm{GEE}^{15}$. Ainda em 2019, o desmatamento na Amazônia repercutiu no mundo todo com dados calamitosos, que apontaram uma quebra do recorde por parte do Brasil entre agosto de 2018 a julho de 2019 com 29,5\% de crescimento do desmatamento, representando $9762 \mathrm{~km}^{2}$ (PRODES, 2019).

Mesmo com os compromissos firmados pelo Brasil nas COPs anos anteriores, e com a adoção do PNA como política pública no Brasil, a década de 2010 trouxe novos desafios em relação às ocorrências de extremos climáticos, ao considerar os eventos de seca de São Paulo (2013 a 2015) e no Semiárido brasileiro, em especial no Ceará (2012-2018), somando-se aos casos de inundações e deslizamentos em outras regiões do país (LEITE, 2018; MARENGO et al., 2015).

Os processos relacionados à capacidade do país em se adaptar frente às mudanças climáticas e o poder de mitigação com políticas de combate ao desmatamento e emissão de GEE são colocados em dúvida ao identificar a posição do país frente ao tema. Portanto, é possível inferir que a agenda brasileira na questão climática ainda é conservadora (DI GIULIO et al., 2019).

\subsection{EVENTOS EXTREMOS CLIMÁTICOS - PERCEPÇÕES E RISCOS}

Neste trabalho, percepção de risco é compreendida como as percepções que os indivíduos têm sobre riscos (como aqueles associados às mudanças climáticas), as quais refletem o processamento dos sinais físicos que observam por meio dos seus sentidos e das informações que recebem, e como formam seus julgamentos. Neste processo, para além dos valores e visões de mundo, as relações institucionais, clima social, experiências pessoais, informações, conhecimento, confiança, incertezas e controvérsias são relevantes (RENN, 2008; DI GIULIO et al., 2015).

Perceber o risco é uma construção mental (SJÖBERG, 2000; VAN DER LINDEN, 2017) e a construção da percepção humana concentra entre a existência de ameaças objetivas do mundo real, como as mudanças climáticas, e a percepção subjetiva da avaliação dessas ameaças (ROSA, 2003; VAN DER LINDEN, 2017; DI GIULIO, 2015). As ações de engajamento para que a sociedade perceba o seu papel diante das mudanças climáticas pode variar muito de como ela experimenta as mudanças climáticas, seja de maneira direta ou

\footnotetext{
15 https://g1.globo.com/natureza/noticia/2019/12/15/cop-25-veja-repercussao-do-acordo-que-adiou-para-2020-
} decisoes-sobre-combate-ao-aquecimento-global.ghtml acessado em 19 de fevereiro de 2020 
secundária - por meio da imprensa, mídias sociais (DEMSKI et al., 2017). Como exemplo, as mudanças climáticas observadas no Brasil podem influenciar uma maior ocorrência de eventos extremos climáticos relacionados à seca ou alta precipitação, alterando o cotidiano da população, impondo novos desafios para formulação de políticas públicas e para a resiliência de infraestruturas urbanas (DIAS, 2014). Mesmo que os riscos associados às mudanças climáticas sejam observados há décadas, e não somente de maneira isolada, seu julgamento varia de um indivíduo para o outro (HINE et al., 2013).

Alguns estudos já observaram que existe conexão entre eventos extremos climáticos e crenças individuais nas mudanças climáticas. BORICK et al. (2010), por exemplo, expuseram que crenças sobre mudanças climáticas estão associadas a eventos de alta precipitação e seca; todavia, BRULLE et al. (2012) não encontraram associação direta entre estes eventos extremos climáticos e a percepção dos indivíduos em relação às mudanças climáticas (HONISKY et al., 2016).

DEMSKI et al. (2017), ao desenvolverem uma pesquisa para captar a percepção dos britânicos em relação aos eventos extremos climáticos, encontraram situações similares aos de BORICK et al. (2010) e concluíram que a conexão entre experiências das mudanças climáticas por meio da observação dos eventos extremos é cada vez mais intrínseca, o que pode dificultar o envolvimento também das autoridades por depender de cada vivência com algum fenômeno relacionado.

Eventos hidrometeorológicos (inundações, deslizamentos) e grandes secas expõem a população a situações de riscos, seja por perdas socioeconômicas ou pela mortalidade (COMISSÃO DE MEIO AMBIENTE E DESENVOLVIMENTO SUSTENTÁVEL, 2019). Isso não significa, contudo, que estas experiências ajudam a criar uma percepção automática por parte dos diferentes grupos sociais sobre os impactos das mudanças climáticas, como propõem BORICK et al. (2010). As mudanças climáticas, para muitos, ainda são imperceptíveis (DEMSKI et al., 2017), e para a sociedade, num espectro geral, o clima somente é observado pela alteração sazonal provocada dentro de um próprio período. Os elementos de identidade e sua relação com lugares, trazidos por HERBER (2004), também são importantes, já que os indivíduos entendem que os locais em que vivem são importantes para a continuidade da construção das identidades, mesmo que estas áreas sejam consideradas de riscos.

As alterações nos eventos de secas e alta precipitação, assim como outros fenômenos, são observadas de maneira mais incisivas pela comunidade científica ao considerar fatores como urbanização cada vez mais acentuada, emissões de GEEs e o uso e ocupação irregular 
do solo (DIAS, 2014). Contudo, autores que se debruçam sobre o campo da percepção e riscos sobre mudanças climáticas atribuem o baixo engajamento da sociedade ao fato de que, para a maioria dos indivíduos, esse fenômeno não é considerado como prioridade frente a outros problemas, como saúde, economia ou até mesmo terrorismo (LORENZONI et al., 2006; VAN DER LINDEN, 2017). Estudos ainda apontam que os riscos inerentes às mudanças climáticas parecem ter mais relevância para indivíduos que vivem em nações em desenvolvimento (VAN DER LINDEN, 2017).

Para jogar mais luz no debate sobre as percepções de risco acerca das mudanças climáticas, SHI et al. (2016) discorrem sobre os valores e visões de mundo. Em linhas gerais, os valores gerais se assemelham aos princípios de vida, enquanto visões de mundo refletem as orientações das pessoas em relação a diferentes acordos. Os autores apresentam três abrangentes valores gerais na formação de percepções sobre riscos ambientais: valores egoístas (referem-se somente ao grau de interesse próprio); valores sócio altruísticos (consideram o bem-estar alheio) e valores biosféricos (observam a importância da natureza e do meio ambiente). Para SHI et al. (2016), as percepções de riscos sobre as mudanças climáticas têm ligação com os valores biosféricos. Assim, as pessoas que se identificam com uma forte crença na importância da autoridade e autoconfiança demonstram níveis mais baixos de preocupação com a mudança climática quando comparadas a indivíduos que se identificam mais fortemente com valores igualitários e comunitários.

Os conceitos dos autores são análogos ao que WEBER (2010) apresenta sobre entender as percepções de riscos a partir de fatores psicológicos e culturais. Enquanto para os cientistas, a construção da percepção se baseia na obtenção dos resultados por meio de pesquisas, para o público em geral, esta percepção só vai ser construída aos poucos por meio da afetividade, das informações que vão recebendo e da maneira como tais informações são interpretadas (DI GIULIO et al., 2015).

O "aquecimento global”, assim popularmente conhecido, tem relação com aspectos que, para muitos, fogem das ações individuais de mitigação e adaptação, e reforçam a dificuldade da sociedade, como um todo, em perceber as mudanças climáticas de maneira mais atenta, e reconhecer os riscos (PINHEIRO et al., 2018). Como sugerem esses mesmos autores, a relação dos impactos dos eventos extremos e a percepção é construída, sobretudo, a partir de eventos ocorridos mais recentemente - em casos de várias ocorrências em tempos curtos, sempre o que remete ao mês anterior é o que vem à tona na conformação da percepção.

RENN (2000) destaca outros elementos para justificar uma maior ou menor percepção dos indivíduos acerca dos riscos das mudanças climáticas: 
- Familiaridade com as fontes de riscos;

- Habilidade em controlar pessoalmente os graus de riscos;

- Percepção sensorial do perigo;

- Clareza quanto à informação do risco.

Todos estes componentes se somam aos apontamentos de VAN DER LINDEN (2017) sobre como a percepção de riscos da sociedade sobre as mudanças climáticas é complexa e variada, e como a percepção individual pode ser incompatível com a preocupação mundial que é expressa de maneira mais genérica nas convenções mundiais. Igualmente, a maneira como cada indivíduo percebe os riscos das mudanças climáticas diverge de como ele enxerga estes riscos para os outros. O Quadro 2 traz uma síntese dos conceitos abordados nos subcapítulos referentes as mudanças climáticas.

Quadro 2 - Síntese dos conceitos dos subcapítulos 2.1 e 2.2

\begin{tabular}{|c|c|}
\hline CONCEITO & DEFINIÇÃO \\
\hline Adaptação (IPCC, 2007) & $\begin{array}{l}\text { Se preparar para o enfrentamento dos efeitos } \\
\text { independentemente dos impactos - negativos } \\
\text { ou positivos - causados pelas mudanças } \\
\text { climáticas; processos de ajustes para } \\
\text { antecipar impactos } \\
\text { vulnerabilidades. }\end{array}$ \\
\hline $\begin{array}{l}\text { Percepção de Risco (RENN, 2008; DI } \\
\text { GIULIO et al., 2015). }\end{array}$ & $\begin{array}{l}\text { Percepção de risco é compreendida como as } \\
\text { percepções que os indivíduos têm sobre } \\
\text { riscos (como aqueles associados às mudanças } \\
\text { climáticas), as quais refletem o } \\
\text { processamento dos sinais físicos que } \\
\text { observam por meio dos seus sentidos e das } \\
\text { informações que recebem, e como formam } \\
\text { seus julgamentos. }\end{array}$ \\
\hline Mitigação (IPCC,1995) & $\begin{array}{l}\text { Intervenção humana na redução da emissão } \\
\text { de gases atmosféricos poluentes como } \\
\text { estratégia para reduzir os efeitos das } \\
\text { mudanças climáticas. }\end{array}$ \\
\hline
\end{tabular}




\begin{tabular}{|l|l|}
\hline \multicolumn{1}{|c|}{ CONCEITO } & \multicolumn{1}{|c|}{ DEFINIÇÃO } \\
\hline Mudanças Climáticas (IPCC, 2007) & $\begin{array}{l}\text { Mudanças no clima ao longo de períodos, } \\
\text { com ou sem a interferência humana } \\
\text { (antropogênicas), considerando a } \\
\text { variabilidade das temperaturas, umidade, } \\
\text { pluviometria. }\end{array}$ \\
\hline Eventos extremos climáticos (IPCC, 2011) & $\begin{array}{l}\text { Ocorrências como ondas de calor intensas, } \\
\text { secas prolongadas, chuvas torrenciais em } \\
\text { períodos curtos etc. }\end{array}$ \\
\hline
\end{tabular}

Fonte: Elaboração do autor

\section{3 - CONTEXTOS DO SANEAMENTO BÁSICO}

No Brasil, a denominação saneamento básico é uma representatividade de quatro serviços urbanos, conforme consta na Lei de Diretrizes Nacionais do Saneamento (LDNSB) 11.445/2007: i. abastecimento de água; ii. esgotamento sanitário; iii. limpeza urbana e manejo de resíduos sólidos urbanos; iv. manejo de águas pluviais urbanas. Anterior à LDNSB de 2007, pode-se dizer que os serviços de saneamento básico no Brasil eram regidos pelo Plano Nacional de Saneamento Básico (PLANASA), entre 1964 a 1986 (PEREIRA, 2019). Na Constituição Federal de 1988, na qual foi estabelecida a descentralização política com a definição dos três níveis de poder (União; Estados; e Municípios), o art. 30, V define que a prestação dos serviços de saneamento básico compete ao Município, pois compreende que são serviços de interesse local (BARROSO, 2002):

\footnotetext{
"Art. 30. Compete aos Municipios: (...) $V-$ Organizar e prestar, diretamente ou sob regime de concessão ou permissão, os serviços públicos de interesse local, incluído o de transporte coletivo, que tem caráter essencial"
}

Ainda que a Constituição Federal apresente outros mecanismos legislativos em cada nível de poder em relação ao saneamento básico, assim como para a gestão dos recursos hídricos, desde 1971, no PLANASA, com a criação das 27 companhias estaduais de saneamento (CESBs), a concessão principalmente dos serviços de água e esgoto nos municípios se mantêm com as empresas estatais - atingindo cerca de $75 \%$ dos municípios 
brasileiros; $19 \%$ dos municípios brasileiros são atendidos por alguma autarquia/secretaria/departamento municipal; e 6\% são operados pelas companhias privadas (ABCON, 2019; BRASIL, 2019). No início da década de 2010, 81\% dos recursos para saneamento básico estavam concentrados nas companhias estaduais (AGÊNCIA NACIONAL DAS ÁGUAS, 2010). Os dois estados analisados nesta dissertação têm as empresas estatais de saneamento originárias desta época, sendo a Cagece (Ceará) fundada em 1971, por meio da Lei 9.499; em São Paulo, a Sabesp foi fundada em 1973, por meio da Lei Estadual no 119.

Após décadas de tentativas de estabelecer novas diretrizes para o saneamento básico no Brasil, foi em 2007, com a LDNSB, que a União desenvolveu um planejamento mais abrangente para o setor, instituindo regras, deveres e mais clareza nos papéis institucionais acerca dos quatro serviços de saneamento básico (FURTADO, 2008; PEREIRA, 2019). Um dos princípios fundamentais incorporados à estruturação da LDNSB é de compreender que os serviços de saneamento básico promovem, dentre outros aspectos, a prevenção de doenças de veiculação hídrica, conforme consta no Art. $2^{\circ}$, parágrafo III; portanto, a diretriz de acesso universal ao saneamento básico deve levar em conta a promoção da saúde. Outros aspectos também são citados na Lei, como a equidade, proteção ambiental, a integralidade e o controle social. Este último é um item de constante resistência das CESBs que, na grande maioria, se opõem à participação da sociedade civil, que tem papel importante no fomento dos Planos Municipais de Saneamento Básico (PMSBs), de responsabilidade do ente Municipal (COSTA, 2009; PEREIRA, 2019).

Historicamente, com a predominância das CESBs na prestação dos serviços de água e esgotamento sanitário nos municípios brasileiros, a coleta e tratamento de esgoto têm deficiências estruturais e com carências distintas variando entre as UFs. Os últimos dados apresentados, em 2018, identificaram que $46,85 \%$ da população do país não possuíam coleta e tratamento de esgoto; já o acesso ao abastecimento de água chegava a maior parte da população brasileira, mas 16,38\% ainda não possuíam este serviço (BRASIL/SNIS, 2019). Na Tabela 1 são mostrados os dados extraídos do Sistema Nacional de Informações sobre Saneamento (SNIS) do Ministério do Desenvolvimento Regional (MDR), de 2010 a 2018, referente à população com acesso aos dois serviços, o volume de esgoto tratado, e os investimentos realizados no mesmo período: 
Tabela $1^{16}$ - Atendimentos totais de água (população com acesso); de esgoto referido aos municípios atendidos com água (população com acesso ao esgoto); e investimentos realizados em água e esgotamento sanitário (BRASIL, 2018; BRASIL, 2017; BRASIL, 2016; BRASIL, 2015; BRASIL, 2014; BRASIL, 2013; BRASIL 2012; BRASIL 2011)

\begin{tabular}{|c|c|c|c|c|}
\hline $\begin{array}{c}\text { ANO DE } \\
\text { REFERENCIA }\end{array}$ & $\begin{array}{c}\text { IN 055 - Índice } \\
\text { de } \\
\text { Atendimento } \\
\text { Total de Água } \\
(\%)\end{array}$ & $\begin{array}{c}\text { IN 056 - Índice } \\
\text { de atendimento } \\
\text { total de esgoto } \\
\text { referido aos } \\
\text { municípios } \\
\text { atendidos com } \\
\text { água }(\%)\end{array}$ & $\begin{array}{c}\text { IN 046 - Índice } \\
\text { de Esgoto } \\
\text { Tratado referido } \\
\text { à Água } \\
\text { Consumida (\%) }\end{array}$ & $\begin{array}{c}\text { Investimentos } \\
\text { realizados em água } \\
\text { e esgotamento } \\
\text { sanitário (R\$ } \\
\text { bilhões) }\end{array}$ \\
\hline 2011 & 82,6 & 47,4 & 36,3 & $8.378,3$ \\
\hline 2012 & 82,8 & 48,3 & 37,8 & $9.753,7$ \\
\hline 2013 & 82,5 & 48,7 & 37,8 & $10.449,8$ \\
\hline 2014 & 83,1 & 49,9 & 39,7 & $12.197,7$ \\
\hline 2015 & 83,3 & 50,3 & 41,7 & $12.175,1$ \\
\hline 2016 & 83,3 & 51,9 & 44, & $11.511,0$ \\
\hline 2017 & 83,4 & 52,4 & 45,1 & $10.961,9$ \\
\hline 2018 & 83,62 & 53 & 46 & $13.160,6$ \\
\hline
\end{tabular}

Fonte: Elaboração do autor

Estas defasagens foram bases de sustentação para a elaboração do Plano Nacional de Saneamento Básico (PLANSAB), em 2013, pelo Governo Federal, aprovado pelo Decreto ${ }^{\circ}$ 8.141 e pela Portaria ${ }^{\circ} 171$, de 09 de abril de 2014, de 5 de dezembro de 2013. O PLANSAB é o instrumento vigente no Brasil que propõe políticas de saneamento a partir de investimentos e planejamento para os próximos 20 anos, a contar de 2014, data da promulgação, e foi desenvolvido em três etapas visando os seguintes aspectos (HELLER et al., 2013):

1. Pacto pelo Saneamento Básico - procurou a adesão da sociedade para fundamentação dos eixos e estratégias, com a participação do Conselho das Cidades, formado por 71 representantes eleitos ou indicados por diferentes setores sociais;

\footnotetext{
${ }^{16}$ Os dados de 2019 só serão disponibilizados após a coleta do MDR, previsto para abril de 2020 http://www.snis.gov.br/ acessado em 09 de fevereiro de 2020
} 
2. Panorama do Saneamento Básico no Brasil - foram realizadas pesquisas de diferentes âmbitos para entender o contexto histórico brasileiro no saneamento básico, os investimentos já realizados, os atores mais participativos, com a produção de cadernos temáticos;

3. Consulta Pública - foi submetido à sociedade o Panorama do Saneamento Básico no Brasil para promover o debate e coletar visões a fim de consolidar o PLANSAB para a execução.

Dentre vários aspectos importantes identificados pelo PLANSAB e proposto pelo mesmo, desponta a avaliação sobre a precarização dos serviços de saneamento básico no Brasil, gerenciados majoritariamente pelos sistemas públicos devido à ausência de órgãos gestores, sem estruturas institucionais, quiçá recursos financeiros para planejar, organizar e executar os serviços de água e esgoto em boa parte dos municípios brasileiros, principalmente nos menores. Ainda no Brasil, tanto pela LDNSB, quanto no PLANSAB, o setor do saneamento concentra as discussões em torno dos investimentos necessários para alcançar a universalização dos serviços propostos, uma vez que os esforços públicos frente ao déficit de população sem atendimento ainda estão abaixo do estabelecido pelo PLANSAB ${ }^{17}$. Estima-se que, de 2014 a 2033, o Brasil invista cerca de $\mathrm{R} \$ 300$ bilhões para universalizar os serviços de água e esgoto; este dado já foi contestado por organizações do setor de saneamento, que projetam até $\mathrm{R} \$ 500$ bilhões para o mesmo período ${ }^{18}$, dado o atraso da evolução dos indicadores na década de 2010. De acordo com os dados do Governo Federal, os investimentos estão na média de R \$ 13 bilhões, abaixo do necessário (BRASIL, 2019).

Como meta acordada em âmbito internacional, em 2015, o Brasil assinou a Agenda 2030 proposta pela Organização das Nações Unidas (ONU), incluindo o ODS 6 que visa garantir disponibilidade e manejo sustentável da água e saneamento para todos para todos até 2030, três anos antes da meta proposta pelo PLANSAB.

\subsection{1 - Serviços de água e esgoto e a relação com as mudanças climáticas}

Entre os desafios para suprir a demanda de abastecimento de água e esgotamento sanitário, o setor de saneamento básico no Brasil também deve sofrer impactos relacionados

\footnotetext{
17 https://g1.globo.com/jornal-nacional/noticia/2019/07/23/investimento-em-saneamento-basico-no-brasil-caipelo-terceiro-ano-seguido.ghtml acessado em 07 de fevereiro de 2020

18 https://valor.globo.com/brasil/noticia/2019/04/01/no-ritmo-atual-brasil-so-universaliza-saneamento-apos2060-diz-cni.ghtml acessado em 07 de fevereiro de 2020
} 
às mudanças climáticas e seus eventos extremos (BRITO et al., 2010). Nesta perspectiva é importante salientar que a relação com os recursos hídricos é direta, embora saneamento e recursos hídricos do ponto de vista legal são sistemas opostos com diferentes legislações, atribuições e gestão, sendo o saneamento básico um usuário dos recursos hídricos (BRITTO et al., 2010). A dificuldade de garantir a resiliência dos serviços de saneamento básico perante às incertezas das mudanças climáticas no cenário global e às necessárias adaptações locais pode trazer consequências para a saúde humana, particularmente se a qualidade e quantidade de água para abastecimento humano forem prejudicadas (OATES et al., 2014; RANGER, 2013; CALOW et al., 2011). A água é a principal preocupação quando o assunto é o impacto das mudanças climáticas para a sociedade, sobretudo nos contextos de secas, em que o abastecimento humano é comprometido devido à redução das vazões dos mananciais. O aumento de temperatura pode causar mudanças na qualidade e quantidade também das águas subterrâneas (OATES et al., 2014), recurso natural que no Brasil é o mais extraído para diversos usos (agrícolas; abastecimento humano; rural; indústria; e etc.), com destaque para São Paulo, Piauí, Ceará, Rio Grande do Sul, Bahia e Paraná, estados que mais dependem dessa água (HIRATA et al., 2019).

A mudança no ciclo da água causada pela alteração dos padrões de precipitação já modificou o que é conhecido como "estacionário", isto é, a flutuação natural dos sistemas de variação fixa (DIAZ et al., 2014). Esses autores defendem que não é mais possível fazer planejamento nos sistemas de abastecimento de água ou na infraestrutura sanitária baseado nestes modelos de variação fixa, uma vez que tais modelos não são mais confiáveis considerando os cenários e projeções das mudanças climáticas.

OATES et al. (2014) defendem que as soluções adaptativas às mudanças climáticas no setor de saneamento básico devem concentrar esforços na governança e nos sistemas, já que a adaptação precisa ser considerada em um contexto amplo de ações, e não somente considerando as alterações do clima como um único problema. Dentre diversas recomendações acerca do fortalecimento de governança para o serviço de saneamento básico, os autores destacam:

I. Desenvolver diretrizes e padrões técnicos relevantes para as mudanças climáticas;

II. Compreender melhor a variabilidade climática existente e seus impactos nos recursos hídricos e serviços de saneamento básico; 
III. Escolher fontes de abastecimento de água menos vulneráveis a variações causadas por mudanças climáticas, aumento da competição pela água, ou qualquer outro fator;

IV. Desenvolver projeto de sistemas de tratamento de água e esgoto para permitir mudanças futuras na qualidade da água;

V. Fomentar a construção de latrinas e/ou outras tecnologias de saneamento menos propensas às inundações ou que sejam facilmente substituídas em caso de inundação.

YANG et al. (2017) explicitam que as mais costumeiras abordagens em relação ao aumento da capacidade de resiliência dos sistemas gerenciados pelas companhias de saneamento básico não são processos exclusivos, ou distintos, mas sim de pressão provocada aos agentes, que geram uma resposta. Os autores identificam que os processos essenciais para criar resiliência climática são: a) identificação dos impactos das mudanças climáticas; b) avaliação de vulnerabilidade; e c) desenvolvimento de recomendações de resiliência.

Como um método de identificação de impactos das mudanças climáticas, o volume de chuva acima do normal, culminando em inundações, potencializa a proliferação de doenças em lugares com ausência da coleta e tratamento do esgoto, onde há riscos de contaminação devido ao contato com este efluente não tratado (SMITH, 2015). Parâmetros físico-químicos da água podem ser facilmente comprometidos com a elevação da temperatura somado ao volume de chuva acima do normal, como a elevação da turbidez e contaminação fecal, que afetam a potabilidade da água, ocasionando mais custos para a operação das estações de tratamento de água (ETAs), caso os sistemas não sejam reavaliados (BRITTO et al., 2010). Diante destas ocorrências, BRITTO et al. (2010) também chamam atenção para as estações de tratamento de esgoto (ETEs) que recebem uma quantidade acima do normal de volume residual em períodos de alta precipitação, ocasionando mau funcionamento e interrupção dos serviços. Estas anomalias podem ser observadas a ponto que se gera um refluxo interno dos esgotos, assim como as pressões internas elevadas nos coletores de esgotos, e até uma sobrecarga hidráulica das estações de tratamento de esgoto - ETEs (BRITTO et al., 2010).

Para as áreas que não dispõem de redes coletoras de esgotamento sanitário, o uso de fossas sépticas para coleta dos resíduos se torna frequente, podendo ser inviabilizadas devido à elevação do lençol freático dado o volume de chuva em períodos curtos; nestes casos, o dano ambiental e à saúde humana pode ser ainda mais sentido (BRITTO et al., 2010). Como 
atestam diversos materiais de comunicação social e matérias jornalísticas, as infraestruturas de esgotamento sanitário, quando presentes nos centros urbanos, podem apresentar anomalias em épocas de alta precipitação, devido às ligações irregulares das águas pluviais nestas redes.

Ainda em relação às ETEs, um fator determinante que está intrinsecamente ligado às mudanças climáticas é a geração do gás metano $\left(\mathrm{CH}_{4}\right)$. Para melhor compreender este fenômeno, BILOTTA et al. (2016) explicam que o gás metano, responsável pela capacidade calorífica do biogás, é produzido na degradação biológica anaeróbia da matéria orgânica, com a formação de amônia, dióxido de carbono, hidrogênio, monóxido de carbono, nitrogênio, compostos orgânicos voláteis, sulfetos e fosfatos.

No caso das ETEs, quanto maior for a carga de tratamento biológico, maior será a produção do metano. Sendo assim, abre-se uma discussão se o $\mathrm{CH}_{4}$ e outros gases emitidos pelas ETEs podem acelerar as alterações do clima localmente, uma vez que o metano tem um impacto 20 vezes maior do que o $\mathrm{CO}_{2}$ na atmosfera, elevando os riscos de aumento na temperatura (TARGINO et al., 2017).

$\mathrm{Na}$ LDNSB e no PLANSAB, as diretrizes para a infraestrutura de abastecimento de água e esgotamento sanitário não abarcam as mudanças climáticas, tampouco utilizam os termos relacionados aos eventos extremos (secas, inundações, enchentes), evidenciando que nas políticas nacionais de saneamento do país não se considera a temática para alocação de investimentos, assim como para a governança dos serviços. Questiona-se, assim, os desafios na infraestrutura urbana a partir das mudanças climáticas (inclui-se a infraestrutura sanitária) com uma regulação mais incisiva, sobretudo quando o bem-estar social e a sustentabilidade dos municípios ficam expostos (BOSHER et al., 2007).

No Brasil, do ponto de vista legislativo, a regulação só é melhor definida a partir justamente da LDNSB de 2007, que coloca responsabilidade ao titular dos serviços de formular a política pública de saneamento, visando a definição do ente responsável pela regulação e fiscalização dos serviços (MELO et al., 2013). Dentre as responsabilidades do ente regulador, destacam-se (i) a verificação dos cumprimentos de metas e planejamentos dos prestadores de serviços; (ii) a manifestação conclusiva quando há reclamações dos consumidores; (iii) a fixação de regras para execução dos contratos de prestação de serviços; (iv) a auditoria e certificação dos investimentos; e (v) a definição das pautas das revisões tarifárias (GALVÃO JUNIOR et al., 2008; MELO et al., 2013). 
A constituição de agências reguladoras no Brasil para os serviços de saneamento básico se dá baseada nos modelos federais para outros serviços públicos, exigindo que elas sejam independentes, afastadas de decisões políticas e econômicas, em que há previsão de receitas próprias, mandatos fixos para cargos executivos, cujos teores técnicos sejam ferramentas para definição dos mesmos a partir de indicações do Poder Executivo, com arguição do Poder Legislativo (MELO et al., 2013). As agências reguladoras estaduais são adotadas pela maior parte dos municípios brasileiros por serem economicamente mais sustentáveis, ainda que haja outros modelos, como as agências municipais ou consorciadas (GALVÃO JUNIOR et al., 2008; MELO et al., 2013).

Os aspectos avaliados pelas agências reguladoras consideram, além das ações citadas, a eficiência das empresas de saneamento básico a partir do indicador de perdas de água, que tem contribuição direta com a relação da quantidade dos recursos disponíveis para abastecimento humano. Estas perdas ocorrem de maneiras distintas, as mais latentes são por meio de (i) vazamentos; (ii) ligações ilícitas; e (iii) erros de medição. O controle destas perdas significaria uma retirada menor deste recurso do meio ambiente (RIBEIRO et al., 2017). O país registrou, em 2018, 38,45\% de água perdida (BRASIL, 2019), e segundo estudo realizado pelo Instituto Trata Brasil, em 2019, este recurso natural perdido pelas companhias de saneamento básico no país poderia abastecer $30 \%$ da população brasileira no mesmo ano ${ }^{19}$. Para as companhias de saneamento, reduzir as perdas de água significaria também menores custos de captação da água e mais recursos para investimentos no setor por meio do aumento da margem de receita líquida (MELO et al., 2013).

Cabe destacar que não é somente o Brasil que enfrenta estes desafios, já que outros países também têm índices superiores a dois dígitos, como Reino Unido (20,6\%); África do Sul $(33,7 \%)$; Noruega (41\%); Argentina $(42 \%)^{20}$. No momento em que a quantidade da água é vista como desafio constante devido às secas prolongadas, as perdas de água são riscos frente à restrição hídrica nos momentos de escassez e à possibilidade do aumento dos custos operacionais pelas companhias de saneamento, resultando em aumento tarifário para o usuário (PINHO et al., 2018).

Ao mesmo tempo, a resiliência dos serviços de saneamento básico não necessita necessariamente de cenários climáticos projetados para adequar os sistemas, é preciso entender os contextos locais do acesso à infraestrutura sanitária, a demanda e a

\footnotetext{
${ }^{20} \mathrm{http}: / /$ tratabrasil.org.br/images/estudos/itb/Estudo_de_Perdas_2019_5.pdf acessado em 09 de fevereiro de 2020
} 
vulnerabilidade das sociedades para que seja desenhada uma proposta de resiliência dos sistemas de saneamento básico (YANG et al., 2017).

\section{4 - MUDANÇAS CLIMÁTICAS E SANEAMENTO BÁSICO EM OUTROS PAÍSES}

Há pesquisas sendo desenvolvidas em outros países que dão pistas de como o setor de saneamento básico encara os impactos provocados pelas mudanças climáticas, como abordam YANG et al. (2017) no estudo sobre a resiliência dos sistemas de abastecimento de água em Wuhan, China. Os autores apresentam os impactos que os eventos climáticos extremos já causaram à província chinesa e discutem como o setor de abastecimento de água pode aumentar a capacidade adaptativa para não ser impactado no futuro. Estudos conduzidos nos Estados Unidos apontam que $70 \%$ dos estados estadunidenses têm as fontes de água comprometidas devido às mudanças climáticas (DIAZ et al., 2014). Compreender como outros países têm trabalhado a questão climática dentro do contexto da adaptação à infraestrutura de saneamento básico, sobretudo abastecimento de água, pode possibilitar dimensões pertinentes para pensar como o setor no Brasil deve seguir. Neste sentido, as experiências internacionais exploradas suscintamente a seguir são apenas alguns exemplos, discutidos na literatura acadêmica e também pelo próprio setor de saneamento básico, sobre mudanças realizadas no planejamento do setor de saneamento com vistas a melhor gerir os riscos das mudanças climáticas tanto em termos de garantia de abastecimento hídrico como para os negócios das companhias.

\subsection{1 - Israel}

Quando se trata de experiências do setor de água e esgotamento sanitário no mundo nas quais são consideradas as condições climáticas para o planejamento de saneamento básico como política pública nacional, Israel é um grande benchmarking. A maior parte do país é deserto, e o restante é semiárido, desta forma, a demanda hídrica sempre foi um desafio não só para Israel, mas também para os outros países do Oriente Médio, sobretudo porque têm sido observadas quedas pela metade nas precipitações anuais (SIEGEL, 2017). Assim, baseado neste desafio climático imposto à região, a política nacional de Israel para saneamento básico elaborou estudos projetando a demanda hídrica devido às mudanças climáticas. O esgoto tratado foi identificado como mais um meio de recurso hídrico, usado para diferentes tipos de cultura, exceto para aquelas de cultivo de alimentos e/ou consumo 
(SIEGEL, 2017). Todos os esforços acerca de um tratamento eficiente foram cumpridos por Israel. Hoje o esgoto tratado é usado pelos agricultores para irrigação, sendo $1 / 3$ já utilizado para a agricultura, sobrando mais água fresca para o consumo da população, e garantindo mais disponibilidade para momentos de secas prolongadas (SIEGEL, 2017).

As políticas de saneamento em Israel são de natureza mais prática, impondo regras gerais para que as companhias de saneamento foquem na eficiência da prestação dos serviços, a fim de reduzir problemas de gestão que possam comprometer a disponibilidade hídrica para a população israelense considerando o clima observado nos últimos anos (SIEGEL, 2017). A ordem da Autoridade Israelense das Águas é de que as companhias de saneamento básico do país foquem esforços no conserto das infraestruturas locais e busquem tecnologia e inovação para assegurar a segurança hídrica e os serviços de esgotamento sanitário para o país.

\subsection{2 - Inglaterra e País de Gales}

A Inglaterra e País de Gales, que possuem 100\% de operação de companhias privadas de saneamento básico, têm, desde 1989, a presença da OFWAT, reguladora do saneamento básico nos dois países ${ }^{21}$. As empresas de saneamento básico são forçadas a reportar periodicamente os investimentos necessários para garantir o futuro da demanda hídrica, e, desde o final da década de 1990, as mudanças climáticas é um tópico inserido pelas companhias para que os investimentos sejam realizados de maneira efetiva (ARNELL, 2011).

Ainda que a OFWAT não seja um ministério, ou órgão público, a entidade independente é responsável por regular e fiscalizar as diretrizes dos serviços de água e esgotamento sanitário, regidas pela Lei "Water Industry Act" de 1991. As mudanças climáticas são previstas na "Climate Change Policy Statement" (em português, declaração de políticas de mudanças climáticas) desde 2008 pela reguladora, que firmam compromisso entre as companhias de saneamento básico dos dois países a partir de uma série de observações a respeito dos impactos das mudanças climáticas no saneamento básico de modo genérico.

A ação prática proposta pela entidade reguladora está na redução de geração de energia na provisão dos serviços nos dois países ${ }^{22} \mathrm{e}$, ao mesmo tempo, as companhias de saneamento foram forçadas a traçar cenários considerando estiagens severas ou períodos de chuvas

\footnotetext{
${ }^{21}$ https://www.ofwat.gov.uk/about-us/who-we-are/ acessado em 09 de fevereiro de 2020

22 https://www.ofwat.gov.uk/wp-content/uploads/2015/10/pap_pos_climatechange.pdf acessado em 09 de fevereiro de 2020
} 
intensas, internalizando as incertezas das mudanças climáticas e as projeções do clima no futuro (ARNELL, 2011).

\subsection{3 - África do Sul}

O país sul-africano teve um dos episódios mais intensos de seca, quando, a partir de 2015, a Cidade do Cabo iniciou um período de estiagem que perdurou até 2018. Este e outros episódios levantaram uma preocupação na Política Nacional de Saneamento de 2016 do país $^{23}$, liderada pelo Departamento de Água e Saneamento, o que colocou as mudanças climáticas como um dos três tópicos mais importantes para o futuro das empresas de saneamento básico no país. Ainda com problemas em ofertar os serviços de saneamento básico para todo o país, a Política Nacional de Saneamento da África do Sul considera que as tecnologias individuais ou comunitárias, muitas vezes gerenciadas pelas próprias populações, precisam levar em conta os impactos das estiagens de longo prazo e da alta precipitação.

O documento abrange também medidas do ponto de vista legislativo que o país precisa adotar em casos de desastres naturais, criando infraestrutura mais resiliente para reduzir as chances de transmissão de doenças oral-fecal em casos, principalmente, de inundações. Em 2017, na terceira versão do documento "Normas e Padrões para Água Doméstica e Serviços de Saneamento", redigido pelo Departamento de Água e Saneamento, o reúso de água aparece como uma opção diante das incertezas provocadas pelas mudanças climáticas, principalmente após as secas observadas na Cidade do $\mathrm{Cabo}^{24}$.

Essas experiências evidenciam como reconhecimento às mudanças climáticas tem sido aplicado nas estratégias do setor de saneamento básico destes países. Países que passaram por eventos climáticos extremos de maneira mais danosa, como Israel e África do Sul, aplicaram diretrizes relacionadas às mudanças climáticas nas políticas nacionais de saneamento básico ou recursos hídricos.

O impacto na oferta e demanda causado por secas prolongadas é o mais constatado pelas companhias de saneamento básico, mas há outros impactos menos óbvios, de natureza operacional e técnica, como i) a mudança na qualidade da água, ii) aumento de intrusão da água do mar nos sistemas de tratamento de esgoto, que alteram a qualidade do resíduo líquido

\footnotetext{
23 https://www.datocms-assets.com/7245/1574863462-national-sanitation-policy-2016.pdf acessado em 09 de fevereiro de 2020

${ }^{24} \mathrm{https}$ ://cer.org.za/wp-content/uploads/1997/12/National-norms-and-standards-for-domenstic-water-andsanitation-services.pdf acessado em 09 de fevereiro de 2020
} 
tratado a ser descartado na natureza, iii) danos físicos às plantas de tratamento de água (DIAZ et al., 2014). É baseado nestas perspectivas não tão óbvias que é possível destacar as ações aplicadas pela Inglaterra e País de Gales, que consideram as incertezas que as mudanças climáticas podem trazer aos sistemas de saneamento básico, em termos de impactos, e, assim, focam em normas por meio da Agência Reguladora para que as companhias de saneamento básico sigam com estratégias a fim de evitar impactos operacionais e técnicos. 


\section{CAPÍTULO 3 - CONTEXTO DA PESQUISA - CEARÁ E SÃO PAULO}

Este capítulo discorre sobre os contextos socioeconômicos e as políticas ambientais atreladas às mudanças climáticas e saneamento básico que contextualizam os históricos do Ceará e São Paulo mediante às políticas públicas praticadas em ambos os estados que possam servir de subsídios para os capítulos subsequentes quando os temas mudanças climática e saneamento básico aparecem constantemente dentro dos resultados e discussões desta dissertação.

\section{1 - ESTADO DO CEARÁ}

Constituído por três Regiões Metropolitanas e com 184 municípios, o estado do Ceará possui 9.132.078 milhões de pessoas, conforme as estimativas do IBGE de 2019, estando entre as oito Unidades Federativas mais populosas do país. O crescimento populacional no estado nordestino foi acentuado entre 1980 e 2010, com destaque para a taxa de $19 \%$ de crescimento registrada na década de 2000, comparado a 1990, conforme Tabela 2:

Tabela 2 - População e taxa anual de crescimento do Estado do Ceará (IBGE, 2019)

\begin{tabular}{|l|r|r|r|}
\hline \multirow{2}{*}{ UF } & $\begin{array}{c}\text { Ano de } \\
\text { referência }\end{array}$ & $\begin{array}{c}\text { Projeção } \\
\text { de População } \\
\text { (milhões) }\end{array}$ & \multicolumn{2}{|c|}{$\begin{array}{c}\text { Taxa anual de } \\
\text { crescimento }^{25}(\%)\end{array}$} \\
\hline \multirow{4}{*}{ Ceará } & 1980 & 5.288 .429 & $18 \%$ \\
\cline { 2 - 4 } & 1990 & 6.260 .651 & $18 \%$ \\
\cline { 2 - 4 } & 2000 & 7.430 .661 & $16 \%$ \\
\cline { 2 - 4 } & 2010 & 8.623 .766 & $7 \%$ \\
\hline
\end{tabular}

Fonte: Elaborada pelo autor

Para entender mais sobre as projeções de população e a taxa anual de crescimento das Unidades da Federação do Nordeste, faz-se necessário compreender o fluxo migratório da

25 O cálculo de porcentagem para taxa anual de crescimento foi baseado na metodologia do IBGE https://www.ibge.gov.br/apps/populacao/projecao/notatecnica.html acessado em 20 de janeiro de 2020 
população do Nordeste para o Sudeste brasileiro, em especial para o estado de São Paulo, que ocorreu de maneira acentuada a partir de 1950, com a elevação dos salários nos municípios paulistas, acrescidas às oportunidades de emprego, tanto na área urbana, quanto nas áreas rurais (MELO et al., 2019). Os altos níveis de desemprego das áreas urbanas do Nordeste, desencadeados pela vulnerabilidade econômica do país nas décadas de 1970 adiante, e a desigualdade social, foram as principais razões da emigração. A partir da década de 2000, estudos mostram o impacto inverso no retorno dos migrantes, particularmente nos anos seguintes, em que novos programas de políticas públicas e de aceleração da economia foram adotados, impactando o Nordeste de maneira mais proeminente (OLIVEIRA et al., 2005). Conforme dados dos censos do IBGE de 2000 e 2010, é possível observar que a Região Metropolitana de São Paulo (RMSP) recebeu emigrantes em massa da Bahia, Pernambuco e também Ceará; contudo, o próprio estado cearense apresentou redução na participação de migrantes acumulados, confirmando o fenômeno da migração de retorno (MELO et al., 2019).

Para as próximas décadas, as projeções de crescimento de população para o estado do Ceará são negativas, conforme a Tabela 3 mostra:

Tabela 3 - Projeção de População e taxa anual de crescimento do Estado do Ceará (IBGE, 2019)

\begin{tabular}{|c|c|c|c|}
\hline UF & $\begin{array}{l}\text { Ano de } \\
\text { referência }\end{array}$ & $\begin{array}{l}\text { Projeção de } \\
\text { População } \\
\text { (milhões) }\end{array}$ & $\begin{array}{l}\text { Taxa anual de } \\
\text { crescimento }^{26}(\%)\end{array}$ \\
\hline \multirow{4}{*}{ Ceará } & 2030 & 9.624 .466 & $5 \%$ \\
\hline & 2040 & 9.739 .834 & $1 \%$ \\
\hline & 2050 & 9.689 .820 & $-1 \%$ \\
\hline & 2060 & 9.345 .192 & $-4 \%$ \\
\hline
\end{tabular}

Fonte: Elaborado pelo autor

Diversos fatores justificariam essa desaceleração no crescimento populacional no estado do Ceará, incluindo: i. novas configurações das famílias; ii. contínua migração para outras Unidades Federativas; iii. envelhecimento populacional; e iv. aumento da taxa de mortalidade

26 O cálculo de porcentagem para taxa anual de crescimento foi baseado na metodologia do IBGE https://www.ibge.gov.br/apps/populacao/projecao/notatecnica.html acessado em 10 de janeiro de 2020 
da população jovem ${ }^{27}$. Estes fenômenos não são registrados apenas no Ceará; entende-se que (i) o aumento da expectativa de vida do brasileiro e (ii) a redução da taxa de natalidade contribuem para que os estados brasileiros sintam o decréscimo populacional nas próximas décadas (LOURENÇO, 2018).

Ainda que tenha havido emigração entre os estados do Nordeste para o Sudeste no passado, houve o aumento populacional no estado do Ceará que também contribuiu para a proliferação de aglomerados subnormais, conforme o Censo 2010, que aponta 441.937 pessoas residindo nestas ocupações irregulares, o que corresponde a $4 \%$ da população cearense. Além disso, o estado do Ceará tem um dos menores rendimentos nominais mensais domiciliares per capita, registrados no Censo de 2010 , de $\mathrm{R} \$ 855,00$, sendo o $22^{\circ}$ entre as 29 Unidades da Federação. Os diversos problemas sociais e a desigualdade social no estado do Ceará refletem no baixo IDH da UF: 0,682, inferior à média nacional $(0,727)$, ocupando a $17^{\mathrm{a}}$ posição entre as UFs do país.

\subsection{1 - Biomas}

As constantes alterações no ambiente de forma incorreta, sobretudo com as ocupações irregulares, afetam diretamente o bioma da Caatinga (NOBRE, 2011), único no Brasil, e responsável por abranger 10 estados brasileiros, dentre eles o Ceará. Uma das características da Caatinga é a vegetação típica seca durante os meses de ausência de chuva (HAUFF, 2010). A região costeira do Ceará tem o predomínio de tabuleiros e dos campos de dunas e, portanto, a flora costeira cearense consiste de elementos do Cerrado, Caatinga e da Mata Atlântica (MORO et al, 2015). Na Figura 1 é possível ver o predomínio da Caatinga no estado do Ceará:

\footnotetext{
$27 \mathrm{https}$ //diariodonordeste.verdesmares.com.br/editorias/metro/crescimento-populacional-em-fortaleza-e-o-
} menor-em-6-anos-1.1609173 acessado em 10 de janeiro de 2020 


\section{Figura 1 - Bioma do Ceará}

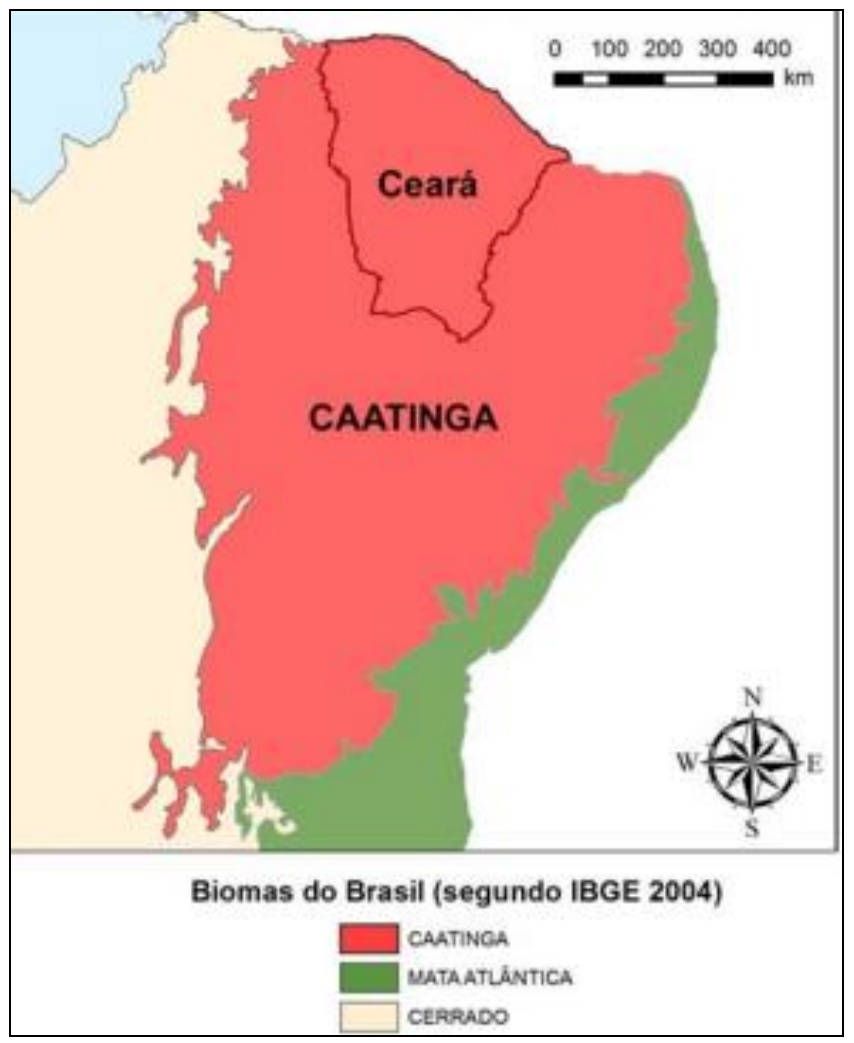

Fonte: Vegetação, unidades fitoecológicas e diversidade paisagística do estado do Ceará (MORO et al., 2015)

A Caatinga tende a sofrer com estiagens mais severas entre a metade e o final do século XXI (MORO et al., 2015), intensificando o debate sobre desertificação deste bioma, que atinge mais outros nove estados em que há o clima semiárido (HAUFF, 2010). Não só o abastecimento de água é vulnerável nas áreas semiáridas do Brasil, como também as atividades agrícolas, que carecem de tecnologia e são altamente dependentes dos recursos naturais (TAVARES et al, 2019). 95\% do território cearense se encontra já em clima semiárido $^{28}$; isso significa que dos 184 municípios, 175 já são classificados como tal, impondo novos desafios econômicos, sociais e ambientais para o estado, principalmente no que concerne às ocupações irregulares nos poucos municípios que ainda não estão nas áreas de seca, como a capital, Fortaleza, que abriga 396.370 dos 441.937 habitantes residentes de aglomerados subnormais do estado (IBGE, 2010).

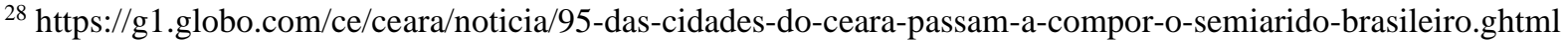
acessado em 10 de janeiro de 2019
} 


\subsubsection{Políticas de Recursos Hídricos e Mudanças Climáticas}

O estado do Ceará institucionalizou as ações relacionadas à convivência com seca com a criação de órgãos permanentes, como: a) Inspetoria de Obras Contra as Secas - IOCS (1909), pelo Decreto $\mathrm{n}^{\circ}$ 7.619, renomeado para Departamento Nacional de Obras Contra as Secas - DNOCS (1945); Superintendência de Desenvolvimento do Nordeste - SUDENE (1959); Companhia de Gestão de Recursos Hídricos - COGERH (1993), com foco na outorga e gestão das águas do estado para os múltiplos usos, principalmente baseada nos conflitos gerados pelas secas anteriores; e o Sistema Integrado de Saneamento Rural (Sisar), em 1996, com objetivo de desenvolver um modelo de gestão de abastecimento de água autossustentável, replicável e eficaz para atender as comunidades rurais quanto à seca.

Uma vez que a seca se torna uma condição para o planejamento de infraestrutura aos estados localizados no semiárido, em especial ao Ceará (LINDOSO, 2013), o gerenciamento dos recursos hídricos tem um planejamento institucionalizado no estado. Em 1983, por exemplo, sendo um dos primeiros do Brasil, o governo do estado criou um grupo para formular a Política Pública de Recursos Hídricos, sendo institucionalizado em 1987, com o objetivo de que os impactos causados pelas secas anteriores fossem minimizados do ponto de vista da gestão da água. Em 1991 foi concluído o Plano Estadual de Recursos Hídricos com o foco na redução dos impactos às secas. Em 1992, por meio da Lei $\mathrm{N}^{\circ} 11.1992$, a partir da Lei Estadual de Política de Recursos Hídricos, foi criado o Sistema de Gestão de Recursos Hídricos - PLANERH. Em 2010, a Lei № 14.844 de 24, que reformula a lei ํo 11.996 de 24 de julho de 1992, instituiu o Sistema Integrado de Gestão de Recursos Hídricos - SINGERH.

Além dos planos voltados aos recursos hídricos, têm sido intensificadas políticas no Ceará para debater e promover ações frente às mudanças climáticas. Abaixo é possível ter uma dimensão de ações importantes promovidas no século XXI:

I. Em 2007, após a publicação do quarto relatório do IPCC, a Secretaria da Ciência, Tecnologia e Educação Superior (Secitece) do estado do Ceará propõe a criação do Fórum Cearense de Mudanças Climáticas e de Biodiversidade, por meio do Decreto Estadual n. 29.272;

II. Em 2008, durante o II Seminário Sobre Mudanças Climáticas: Implicações para o Nordeste, é lançada a 'Carta de Fortaleza', constituída de ideias propostas por técnicos, pesquisadores, especialistas e representantes da 
sociedade civil para o Governo Federal, bem como o governo estadual do Ceará;

III. Em 2010, o Fórum Estadual de Mudanças Climáticas produz o Relatório do Ceará (Ceará Report 2012), apontando os desafios para os próximos 20 anos no estado, sobretudo pontuando as deficiências da Caatinga;

IV. Em 2012, sob o decreto No 30.909, é lançado o Comitê Integrado de Combate à Seca, coordenado pela Secretaria do Desenvolvimento Agrário (SDA), com representantes dos Ministérios do Desenvolvimento Agrário, Desenvolvimento Social e Combate à Fome e das Minas e Energia, além do Exército Brasileiro. Pelo Governo Cearense, estão representantes das Secretarias de Recursos Hídricos, Cidades, Trabalho e Desenvolvimento Social, da Cagece, Superintendência de Obras Hidráulicas (Sohidra), Ematerce e Defesa Civil Estadual, além da Associação dos Municípios do Estado do Ceará (Aprece), Federação dos Trabalhadores da Agricultura do Ceará (Fetraece) e Federação da Agricultura e Pecuária do Ceará (Faec);

V. Em 2015 é lançado o Plano Estadual de Convivência com a Seca prevendo medidas emergenciais, estruturantes e complementares para cinco eixos de atuação: segurança hídrica, segurança alimentar, benefícios sociais, sustentabilidade econômica, e conhecimento e inovação;

VI. Também em 2015, é lançado o Grupo de Contingência da Seca, coordenado pelo Secretário de Recursos Hídricos, com representação da Cagece, Cogerh, Sohidra, Fundação Cearense de Meteorologia e Recursos Hídricos (Funceme), Corpo de Bombeiros e Defesa Civil;

VII. Em 2016, por meio da Lei Nº16.146, é lançado o Plano Estadual de Mudanças Climáticas, com ênfase nas áreas onde estão as Unidades de Conservação do Estado;

VIII. Em 2017, sob o Decreto $\mathrm{N}^{\circ}$ 32285, é instituído o Pacto por um Ceará Sustentável, com o intuito de construir a cultura da sustentabilidade e da justiça socioambiental e econômica, com políticas interinstitucionais de gestão ambiental integrada, voltadas para a convivência com o semiárido, a gestão dos recursos hídricos, o saneamento básico e as energias renováveis;

IX. Em 2019, surge o Programa de Saneamento Básico para Localidade Rurais do Estado do Ceará: Adaptação às Mudanças Climáticas - Programa Águas do 
Sertão, destinado à resiliência e adaptação do sertão cearense em relação à escassez de água e deficiência dos serviços de saneamento básico (esgotamento sanitário), junto ao Banco Alemão de Desenvolvimento (KfW). Um edital foi aberto aos prefeitos e gestores do Sistemas Integrados de Saneamento Rural (Sisar) para que manifestassem interesse.

\subsubsection{Evento extremo climático - seca de 2012 a 2018}

As secas podem ser compreendidas como fenômenos naturais, fazendo parte da variabilidade natural do clima da região Nordeste, principalmente nos estados do Polígono das Secas, que inclui o Ceará e outros sete estados do Nordeste, mais parte do norte do estado de Minas Gerais (MARENGO et al., 2016). No entanto, a seca de 2012 a 2018 é considerada a mais longa nos estados nordestinos, com destaque para o território do estado Ceará, no qual, durante abril de $2018,74,52 \%$ do território teve algum nível de estiagem ${ }^{29}$. COSTA DOS SANTOS et al. (2011, pag. 164) mostram, por meio de análise de dados, que:

"Aumento nas anomalias de temperaturas da
superficie dos Oceanos Pacífico Equatorial e
Atlântico Tropical acarreta em um aumento do
número de dias consecutivos secos no norte do Ceará,
e a anomalia positiva de TSM ao norte do equador,
no Oceano Atlântico, induz que a ZCIT [Zona de
Convergência Intertropical] se desloque para o norte,
inibindo os eventos chuvosos, e aumentando o número
de dias consecutivos secos sobre o norte do Cearâ"

Esse fenômeno teve uma leve trégua no estado do Ceará no primeiro semestre de 2018; todavia, segundo o decreto 32.568, de 16 de abril de 2018, publicado no Diário Oficial do Estado, o número de municípios em estado de emergência devido à seca prolongada foi de 89 , quase $50 \%$ de todo território cearense. Este período registrado de intensa seca intensifica os debates sobre a desertificação do semiárido, que atinge mais outros nove estados, além do Ceará (MMA, 2010). Não só o abastecimento de água é vulnerável nas áreas semiáridas do Brasil, como também as atividades agrícolas, que carecem de tecnologia e são altamente dependentes dos recursos naturais (TAVARES et al., 2019).

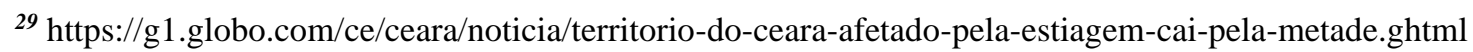
acessado em 20 de janeiro de 2020
} 
Embora as secas no Nordeste sejam frequentes, MENDES (1986) as classifica como estacionais e periódicas, em que a primeira é denominada de estiagem porque ocorre nos segundos semestres, acompanhando o ciclo hidrológico da região, enquanto a segunda tem um grau de impacto muito mais intenso sobre as atividades humanas, bem como na vida animal da região, e todo o ecossistema, pois ocorre de maneira desequilibrada. As classificações para os tipos de seca variam de acordo com as abordagens estudadas até o presente momento, no entanto, TAVARES et al. (2019) citam quatro tipos diferentes:

- Meteorológica: levam-se em conta as precipitações fora da média;

- Hidrológica: ocorre com as secas meteorológicas, associada à baixa precipitação sobre a superfície terrestre e o estoque de água subterrâneo;

- Agrícola: relacionada ao baixo estoque de recursos hídricos para atividade da agricultura;

- Socioeconômica: tem relação direta com o acúmulo ocasionado da seca meteorológica e impacta diretamente as atividades socioeconômicas.

Historicamente, dezenas de períodos longos de seca ocorreram no Ceará, como a síntese proposta no Quadro 3:

Quadro 3 - Evento extremo relacionado à seca no estado do Ceará

\begin{tabular}{|c|c|c|}
\hline UF & $\begin{array}{l}\text { Ocorrência de evento } \\
\text { extremo nos últimos anos }\end{array}$ & $\begin{array}{l}\text { Evento extremo de maior } \\
\text { impacto registrado }\end{array}$ \\
\hline Ceará & $\begin{array}{l}\text { Secas em 1877, 1930, } \\
\text { 1941, 1951, 1979, 2007, } \\
\text { 2010, } 2012 \text { (MONTEBELLO, } \\
\text { 2018; MARTINS, 2015). }\end{array}$ & $\begin{array}{l}\text { Secas de 1877-1879 } \\
\text { (MONTEBELLO, 2018); Secas } \\
\text { de 1951-1954; Secas de 1979- } \\
1983 \text { (MARTIN, 2015); Secas de } \\
\text { 2012-2018 (SILVEIRA et al., } \\
\text { 2018) }\end{array}$ \\
\hline
\end{tabular}

Fonte: Elaborado pelo autor 
Para averiguar sobre as temperaturas máximas, média, mínima e precipitações para o estado do Ceará no passado, foram utilizados dados da base de estudo de XAVIER et al. (2015). No trabalho dos autores foram usados 3.625 pluviômetros e 735 estações automáticas no período de 1980-2013, com atualização até 2016 (XAVIER et al., 2017). É possível observar que as temperaturas máximas, mínimas e médias tiveram acréscimo anual entre estas décadas; enquanto a precipitação acumulada anual teve queda no mesmo período analisado. Os dados do Gráfico 1 evidenciam os achados para o estado do Ceará (os dados do Ceará por ano estão no anexo):

\section{Gráfico 1 - Série histórica de variações do clima}

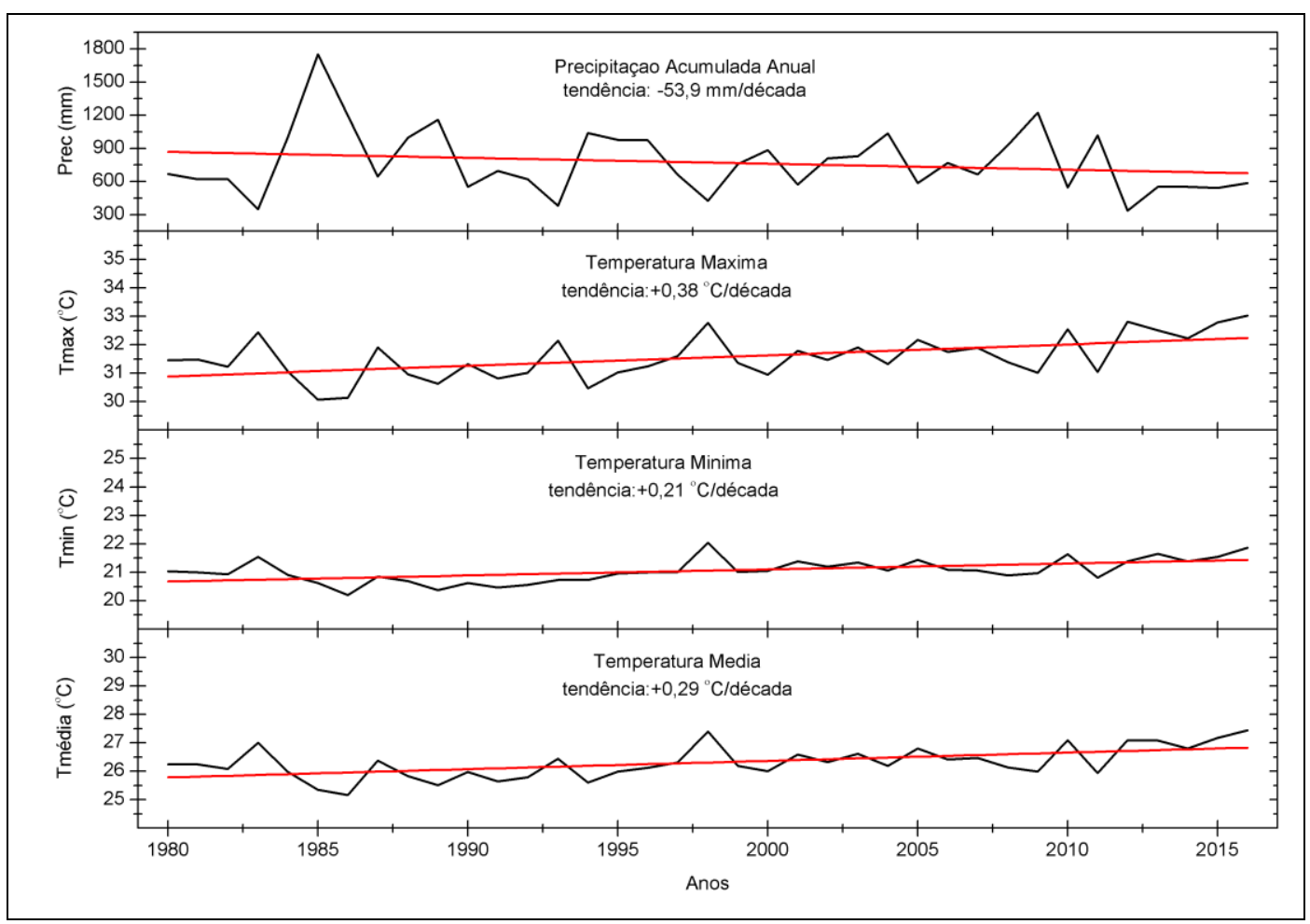

Fonte: Dados extraídos do banco de dados meteorológicos (XAVIER et al., 2017)

Chama atenção nos dados do Ceará de 1980-2015 a diminuição de chuvas de 53,9mm por década, totalizando uma queda de $188,65 \mathrm{~mm}$ em três décadas e meia de análise; o mesmo se aplica às temperaturas, com um acréscimo de $1,33^{\circ} \mathrm{C}$ na temperatura máxima em três décadas e meia, assim como aumento de $0,73^{\circ} \mathrm{C}$ na temperatura mínima, e $1,01^{\circ} \mathrm{C}$ na temperatura média.

Dado o histórico, as projeções futuras para os estados que compõem a Caatinga, como o Ceará, apontam para o decréscimo de chuvas na ordem de $10 \%$ a $20 \%$ até 2040 , tendo um 
aumento gradual da temperatura média para $1,5^{\circ} \mathrm{C}$ a $2,5^{\circ} \mathrm{C}$; até 2100 , as projeções mostram um acréscimo entre $3,5^{\circ} \mathrm{C} \mathrm{a} 4^{\circ} \mathrm{C}$, com menor vazão hídrica devido a diminuição do padrão das chuvas (PBMC, 2014a).

No Quadro 4 é possível identificar alguns dos padrões projetados para o futuro no Nordeste, com foco no Ceará:

Quadro 4-Projeções climáticas para o estado do Ceará

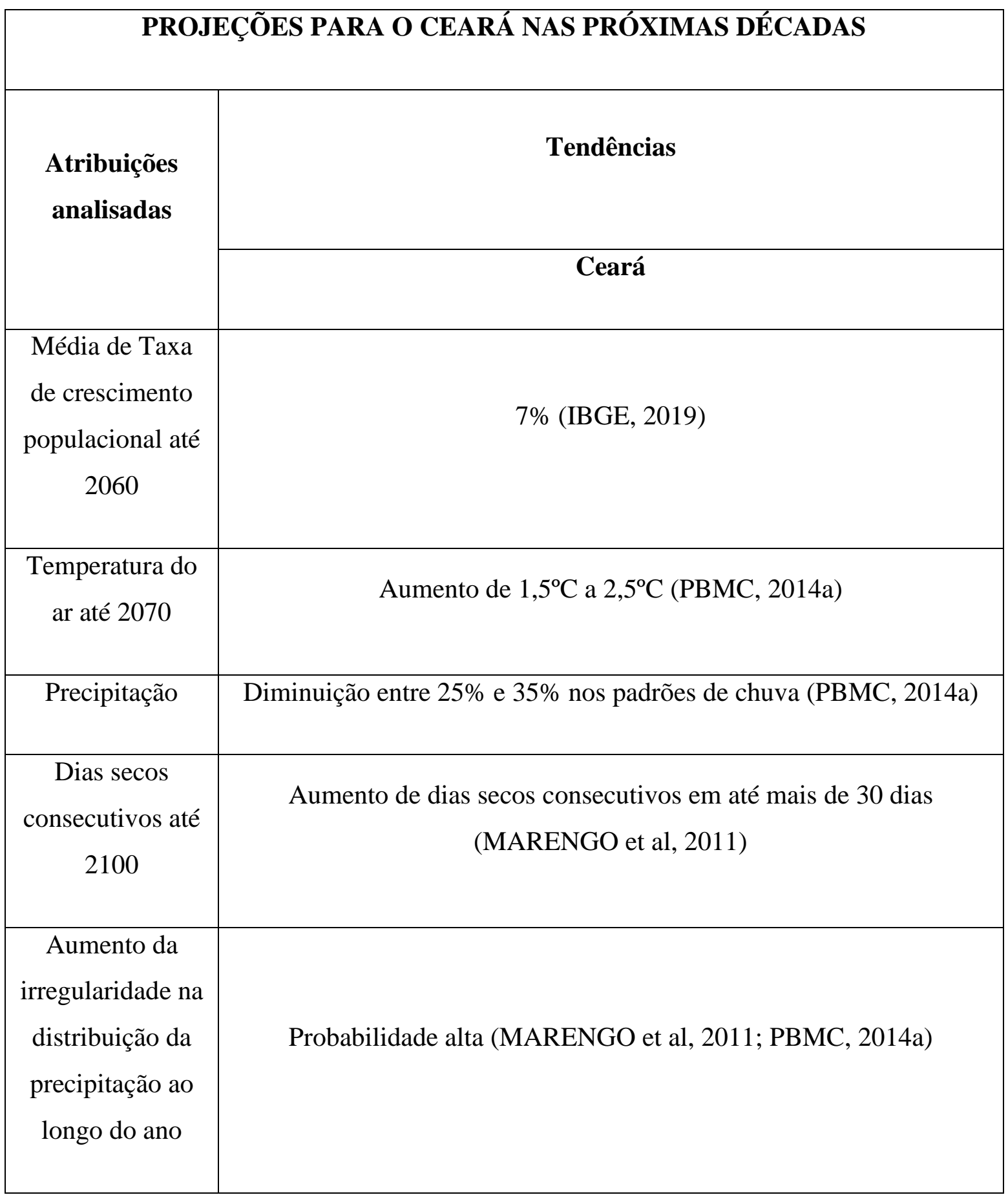

Fonte: Elaborado pelo autor 


\subsection{4 - As Mudanças Climáticas e o setor de Saneamento no Ceará}

O estado cearense tem a política estadual de saneamento promulgada somente em 2016, pela Lei n. 162. Desde o fim de 2019, a Assembleia Legislativa deu início ao Pacto pelo Saneamento Básico no estado cearense, com a composição de instituições, associações e órgãos ligados ao governo estadual ${ }^{30}$. Como uma das entidades membro do grupo, a Cagece é a principal companhia do estado do Ceará, operando em quase $85 \%$ dos municípios; as demais cidades são operadas por alguma autarquia/departamento/secretaria municipal; até o presente momento, não há registros de operação de companhias privadas no estado (ABCON, 2019; BRASIL 2018). A Cagece é uma sociedade de economia mista de capital aberto, em que $88 \%$ pertencem ao Estado do Ceará; $11 \%$ à Prefeitura de Fortaleza; e o restante está em mãos minoritárias. Em 2019, a empresa protocolou prospecto preliminar de oferta pública inicial de ações (IPO em inglês), dessa forma, a companhia teria suas ações vendidas pela primeira vez.

A Arce é responsável por regular e fiscalizar 151 municípios que a Cagece opera em todo o estado ${ }^{31}$, com exceção na capital, Fortaleza, em que a Arce regula a Cagece somente do ponto de vista econômico, enquanto a regulação técnica é feita pela Autarquia de Regulação, Fiscalização e Controle dos Serviços Públicos de Saneamento Ambiental (ACFor). A Secretaria das Cidades é o órgão estadual responsável por planejar, buscar investimentos e auxiliar na execução de obras de saneamento básico no restante do estado, bem como tem a Cagece vinculada ao organograma ${ }^{32}$.

De acordo com os últimos dados extraídos do Diagnóstico de Saneamento Básico do Ministério do Desenvolvimento Regional (MDR) (BRASIL, 2018), 14 outros estados investem mais do que o Ceará na provisão de água e esgoto. Sendo assim, os dados de abastecimento de água e esgotamento sanitário do estado evidenciam os problemas enfrentados pela população há anos com os baixos índices de cobertura de esgoto (Tabela 4):

\footnotetext{
30 https:/www.opovo.com.br/noticias/politica/2019/12/06/novo-pacto-pelo-saneamento-basico-no-ceara-discutequalidade-e-acessibilidade-dos-servicos.html acessado em 10 de fevereiro de 2020

${ }^{31} \mathrm{https}: / / \mathrm{www}$.arce.ce.gov.br/coordenadorias/saneamento/ acessado em 10 de fevereiro de 2020

${ }^{32} \mathrm{https}$ ///www.ceara.gov.br/organograma/cidades/ acessado em 10 de fevereiro de 2020
} 
Tabela 4 - Investimentos realizados e indicadores de acesso ao abastecimento de água e esgotamento sanitário pelo estado do Ceará de 2011 a 2018 (BRASIL, 2018; BRASIL, 2017; BRASIL, 2016; BRASIL, 2015; BRASIL, 2014; BRASIL, 2013; BRASIL 2012; BRASIL 2011)

\begin{tabular}{|c|l|l|l|l|l|}
\hline ANO DE \\
REFERÊNCIA & $\begin{array}{l}\text { IN 055 - } \\
\text { Índice de } \\
\text { Atendimento } \\
\text { Total de } \\
\text { Água (\%) }\end{array}$ & $\begin{array}{l}\text { IN 056 - } \\
\text { Índice de } \\
\text { atendimento } \\
\text { total de } \\
\text { esgoto } \\
\text { referido aos } \\
\text { municípios } \\
\text { atendidos } \\
\text { com água (\%) }\end{array}$ & $\begin{array}{l}\text { IN 046 - } \\
\text { Índice de } \\
\text { Esgoto } \\
\text { Tratado } \\
\text { referido à } \\
\text { Água } \\
\text { Consumida } \\
(\%)\end{array}$ & $\begin{array}{l}\text { IN 049 - } \\
\text { Índice de } \\
\text { Perdas na } \\
\text { Distribuição } \\
(\%)\end{array}$ & $\begin{array}{l}\text { Investimentos } \\
\text { realizados em } \\
\text { água e } \\
\text { esgotamento } \\
\text { sanitário (R\$ } \\
\text { milhões) }\end{array}$ \\
\hline 2011 & 72,90 & 27,80 & 31,70 & 35,3 & 238,0 \\
\hline 2012 & 68,70 & 25,70 & 31,20 & 38,7 & 218,1 \\
\hline 2013 & 69,70 & 25,30 & 32 & 36,5 & 206,2 \\
\hline 2014 & 64,10 & 25 & 32,30 & 40,1 & 256,4 \\
\hline 2015 & 64 & 25,20 & 33,40 & 41,2 & 223,5 \\
\hline 2016 & 64,10 & 25,20 & 34,10 & 40,6 & 159,7 \\
\hline 2017 & 63,30 & 25,80 & 36,10 & 45,5 & 184,3 \\
\hline 2018 & 58,96 & 25,46 & 38,33 & 43,97 & 182,2 \\
\hline
\end{tabular}

Fonte: Elaborado pelo autor

Por ser um estado com áreas rurais dispersas e imersas no semiárido brasileiro, a dificuldade de levar os serviços de água e esgotamento sanitário constitui desafio, especialmente considerando a necessidade de não deixar essa população desabastecida. Em 1996, o Governo do Estado do Ceará, junto à Cagece, e ao banco alemão, Kreditanstalt für Wiederaufbau (KFW), firmaram parceria para levar estes serviços para 45 comunidades rurais, com a ressalva de que os líderes comunitários seriam os agentes responsáveis pela manutenção dos sistemas. Dado as dificuldades econômicas e de gestão, os atores envolvidos estabeleceram a criação de uma organização para auxiliar no gerenciamento dos sistemas desenvolvidos para as comunidades. No mesmo ano, surgiu o SISAR, em que a estruturação se dá da seguinte maneira (ALBUQUERQUE NETO, 2011, pg. 13): 
"Esta forma de organização visa garantir a manutenção, operação e pequenas ampliações destes sistemas, de forma que as comunidades, através das associações comunitárias, possam operar os sistemas $e$ os custos sejam assumidos pelas próprias comunidades. As associações pagam a energia consumida na operação e pagam o operador do sistema e repassam ao SISAR um valor para despesas com tratamento de água e esgoto para manutenção corretiva e preventiva do sistema e para suporte às associações no gerenciamento do sistema. Desta forma o SISAR seria uma organização independente e autossustentável”.

Portanto, este modelo do SISAR visa garantir a segurança hídrica das áreas rurais do estado cearense, mais até do que prover os serviços de esgotamento sanitário, e toda a operação de água dos locais é gerenciada pelas próprias comunidades. O SISAR, enquanto um braço da sociedade, com apoio do governo estadual, desenvolveu ações de convivência com a seca com medidas adaptativas para que a população rural não ficasse desabastecida com água potável. Segundo informações do próprio SISAR em 2015, no auge da crise de 2012 a $2018^{33}$, foram realizadas medidas como perfuração de poços mais profundos, aquisições de adutoras de montagem rápida e dessalinizadores para purificar a água salobra do solo.

O contexto tarifário envolvendo os períodos longos de estiagem no Ceará foi também um dos debates que gerou desconforto na população com a implantação por parte da Cagece da tarifa de contingência, aprovada pelas agências reguladoras, para conter o consumo durante o período mais crítico vivenciado pelo estado nas últimas décadas. A penalidade instituída em 2015 pela Cagece aos consumidores poderia chegar até $120 \%$ sobre o consumo excedente. Até abril de 2019, a companhia estadual já havia arrecadado R \$ 377 milhões com a tarifa de contingência em todo o estado ${ }^{34}$. $\mathrm{O}$ envolvimento do setor de saneamento básico com as estiagens no Ceará se deu justamente por meio da Cagece no Grupo de Contingência instituído em 2015 pelo Governo do Estado do Ceará, quando a companhia estadual de água e esgoto iniciou projetos de construção de adutoras e perfuração de mais poços para minimizar os impactos da seca, além de dar início ao processo de contratação de projeto de

\footnotetext{
${ }^{33}$ http://abes-

es.org.br/drupalBU/sites/default/files/arquivos/apresentacao_modelo_de_gestao_sisar_ceara_outubro_2015.pdf acessado em 10 de fevereiro de 2010

${ }^{34} \mathrm{https}$ //diariodonordeste.verdesmares.com.br/editorias/negocios/arrecadacao-com-tarifa-de-contingencia-dacagece-triplica-em-4-anos-1.2088648 acessado em 10 de fevereiro de 2020
} 
dessalinização do mar em Fortaleza ${ }^{35}$. No Plano de Segurança Hídrica do estado, promulgado em 2017, a responsabilidade da Cagece também está relacionada à intensificação dos programas de redução das perdas de água, para garantir mais recurso natural à população cearense.

\section{2 - ESTADO DE SÃO PAULO}

Composto por cinco Regiões Metropolitanas e três Aglomerações Urbanas, o estado de São Paulo é considerado o mais populoso do país, com aproximadamente 46 milhões de pessoas (IBGE, 2019), com um crescimento de $9 \%$ comparado à população registrada no Censo de 2010. Se a taxa de crescimento populacional no Brasil é acentuada desde a época da industrialização, principalmente a partir de 1970, em que há uma migração da população da área rural para a área urbana, no estado de São Paulo, em particular, a taxa de evolução populacional tem maior expressão de 1970 para 1980, quando houve um crescimento de 39\%, conforme a Tabela 5 mostra:

Tabela 5 - População e taxa anual de crescimento do Estado de São Paulo (IBGE, 2019)

\begin{tabular}{|c|r|r|r|}
\hline \multirow{2}{*}{ UF } & $\begin{array}{r}\text { Ano de } \\
\text { referência }\end{array}$ & $\begin{array}{r}\text { População } \\
\text { (milhões) }\end{array}$ & $\begin{array}{r}\text { Taxa anual de } \\
\text { crescimento }^{36}(\%)\end{array}$ \\
\hline \multirow{4}{*}{ São Paulo } & 1980 & 25.042 .074 & $39 \%$ \\
\cline { 2 - 4 } & 1990 & 30.945 .297 & $24 \%$ \\
\cline { 2 - 4 } & 2000 & 37.032 .403 & $14 \%$ \\
\cline { 2 - 4 } & 2010 & 42.298 .906 & $9 \%$ \\
\cline { 2 - 4 } & $2020^{37}$ & 46.289 .333 & \\
\hline
\end{tabular}

Fonte: Elaborado pelo autor

Devido ao fenômeno da metropolização entre as décadas de 1970 e 1980, que atingiu os estados do Sudeste em massa, as taxas de crescimento se concentraram, sobretudo, nas áreas

\footnotetext{
35 https://www.ceara.gov.br/2017/09/27/maior-seca-da-historia-ceara-quebra-paradigmas/ acessado em 10 de fevereiro de 2020

36 O cálculo de porcentagem para taxa anual de crescimento foi baseado na metodologia do IBGE https://www.ibge.gov.br/apps/populacao/projecao/notatecnica.html acessado em 20 de janeiro de 2020

${ }^{37}$ https://www.ibge.gov.br/apps/populacao/projecao/ acessado em 20 de janeiro de 2020
} 
periféricas das grandes cidades brasileiras. BAENINGER (2004) chama de "processo de periferização", no qual as metrópoles se fragmentam e dividem-se em núcleos (SANTOS, 1994).

Com a urbanização desenfreada nas metrópoles, assim como nos estados com melhores condições econômicas, como São Paulo, esse processo de "periferização" expõe a população à vulnerabilidade social e ambiental com as ausências e ineficiências dos serviços públicos de infraestrutura (MARICATO, 2011; SANTOS, 1994), como abastecimento de água e coleta de esgoto. Denominados pelo IBGE como aglomerados subnormais, as ocupações irregulares correspondem a 5,9\% da população brasileira (IBGE, 2010); somente no estado de São Paulo, este número é de 2.715.067 de pessoas - isto é, 6\% da população paulista. Em estudos realizados sobre os acessos das infraestruturas nestes locais, a ausência do saneamento básico é mais um dos problemas acentuados, atingindo percentagem significativa, como aponta relatório do Instituto Trata Brasil (2016) ${ }^{38}$, que evidencia que $91 \%$ dos esgotos gerados em ocupações irregulares das 100 maiores cidades brasileiras não eram coletados, tampouco tratados. A pesquisa contempla 15 municípios paulistas, sendo eles: Campinas, Carapicuíba, Diadema, Guarujá, Itaquaquecetuba, Jundiaí, Osasco, Praia Grande, Santos, São Bernardo do Campo, São José dos Campos, São Paulo, São Vicente, Sorocaba e Suzano. Somado a esta vulnerabilidade socioambiental, adicionam-se os impactos associados aos eventos extremos provocados pela alteração do clima, como as inundações e secas prolongadas, observados com maior frequência nas grandes cidades brasileiras, resultados também do crescimento populacional, urbanização constante e sem regulação (RIBEIRO, 2008; DI GIULIO, 2017).

Mesmo diante destes desafios, o estado paulista ainda sustenta o segundo melhor rendimento nominal mensal domiciliar per capita da população residente (IBGE, 2018) com $\mathrm{R} \$ 1.898,00$, atrás apenas do Distrito Federal. Outro fator a ser considerado é que o estado de São Paulo também tem o segundo melhor IDH - 0,783 -, atrás do Distrito Federal, com 0,824, no entanto à frente da média nacional, 0,727 (IBGE, 2010).

Segundo as estimativas de projeções do IBGE para 2060, deverá haver uma desaceleração na taxa anual de crescimento populacional para o estado; no entanto, ao analisar o recorte de 2020 até 2050, o IBGE ainda aponta um crescimento no território paulista, conforme mostra a Tabela 6:

\footnotetext{
${ }^{38} \mathrm{http} / / /$ tratabrasil.org.br/estudos/estudos-itb/itb/areas-irregulares acessado em 20 de janeiro de 2020
} 
Tabela 6 - Projeção de População e taxa anual de crescimento do Estado de São Paulo (IBGE, 2019)

\begin{tabular}{|c|r|r|r|}
\hline \multirow{2}{*}{ UF } & $\begin{array}{r}\text { Ano de } \\
\text { referência }\end{array}$ & $\begin{array}{c}\text { Projeção } \\
\text { de População } \\
\text { (milhões) }\end{array}$ & \multicolumn{2}{|c|}{$\begin{array}{c}\text { Taxa anual de } \\
\text { crescimento (\%) }\end{array}$} \\
\hline \multirow{5}{*}{ São Paulo } & 2020 & 46.289 .333 & $9 \%$ \\
\cline { 2 - 4 } & 2030 & 49.315 .046 & $3 \%$ \\
\cline { 2 - 4 } & 2040 & 51.012 .645 & $1 \%$ \\
\cline { 2 - 5 } & 2050 & 51.405 .978 & $-2 \%$ \\
\hline
\end{tabular}

Fonte: Elaborado pelo autor

\subsection{1 - Biomas}

Em décadas passadas, o crescimento populacional desenfreado, a ocupação irregular do solo, as atividades agrícolas e a industrialização acelerada contribuíram para a redução da vegetação no estado de São Paulo (NEDER, 2019). De acordo com o Mapa de Biomas do Estado de São Paulo - Resolução SMA n ${ }^{\circ}$ 146/2017, essa vegetação se encontra em dois biomas presentes atualmente no estado de São Paulo: (i) Bioma Mata Atlântica; (ii) Bioma Cerrado; e, (III) Zona de Tensão (área de contato entre os dois biomas). A Mata Atlântica está em 17 Unidades da Federação do país, abrangendo 145 milhões de pessoas em mais de 3.400 municípios $^{39}$. No estado de São Paulo, ela ocupa uma área de $68,8 \%$ do território paulista, e o Cerrado 31,2\%, no entanto a vegetação nativa presente atualmente da Mata Atlântica é de $16,3 \%$ do território ${ }^{40}$. A Figura 2 apresenta a divisão dos biomas no estado de São Paulo, de acordo com o Mapa de Biomas do Estado de São Paulo:

\footnotetext{
${ }^{39}$ https://www.sosma.org.br/conheca/mata-atlantica/ acessado em 22 de janeiro de 2020

${ }^{40} \mathrm{https} / / /$ www.sosma.org.br/wp-content/uploads/2019/10/Atlas-mata-atlanticaDIGITAL.pdf acessado em $22 \mathrm{de}$ janeiro de 2020
} 
Figura 2 - Biomas do estado de São Paulo

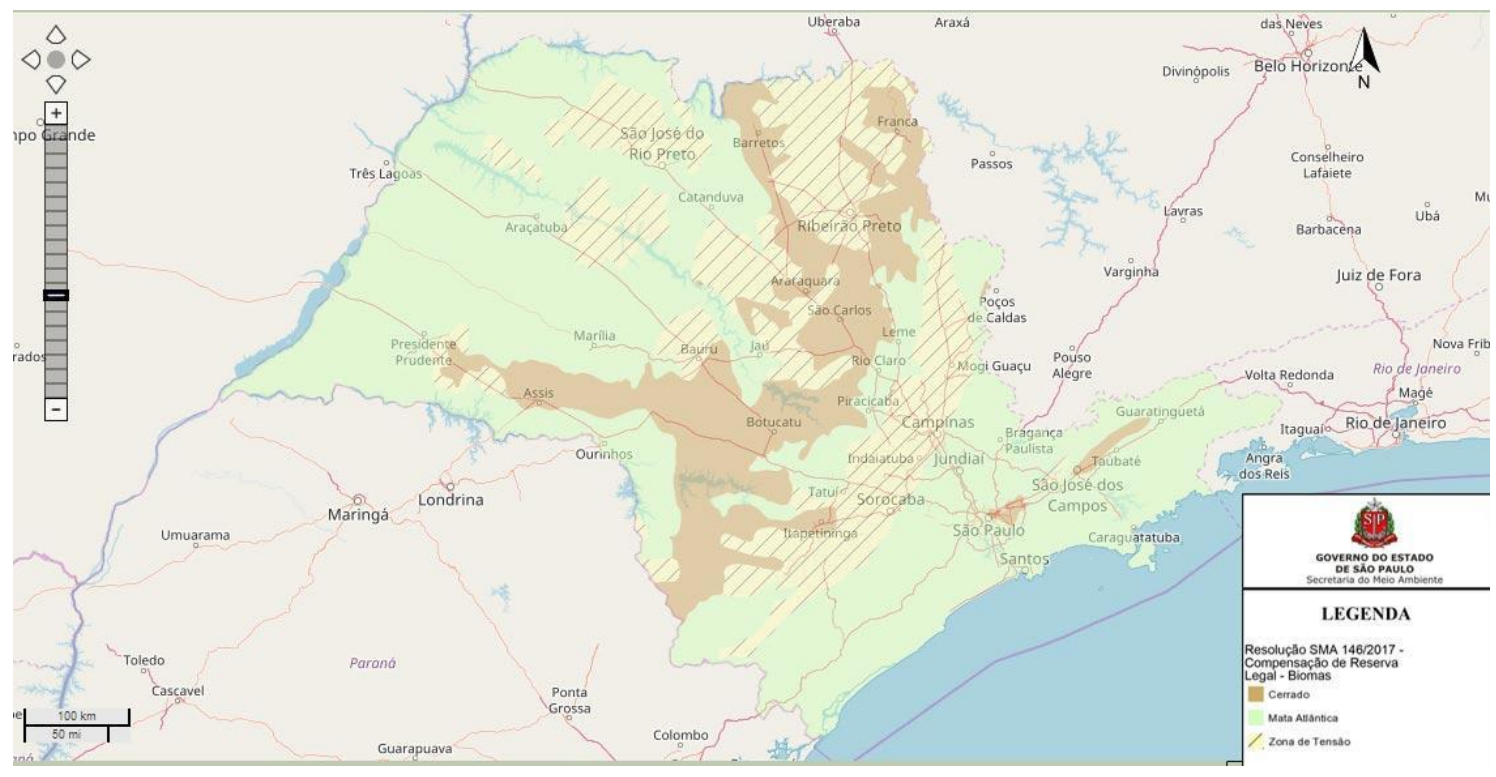

Fonte: Biomas no Estado de SP - RESOLUÇÃO SMA No 146

A recuperação destes biomas é um instrumento estratégico de adaptação às mudanças climáticas e à manutenção da qualidade dos recursos hídricos. A legislação estadual paulista (Lei Estadual 6.134/1988, Decreto Estadual 32.955/1991, Lei Estadual 13.550/2009 e Resolução SMA 64/2009) sugere que haja a proteção de áreas prioritárias para a recarga de aquíferos e de remanescentes de Mata Atlântica e Cerrado (NALON et al., 2019).

Em relação à Mata Atlântica, as áreas que contém a maior parte da vegetação nativa no estado de São Paulo estão concentradas, até o momento, na região Sul e litorais Sul e Norte, conforme a Figura 3 mostra: 
Figura 3 - Figura do estado de São Paulo com decrementos 2017-2018 ressaltados

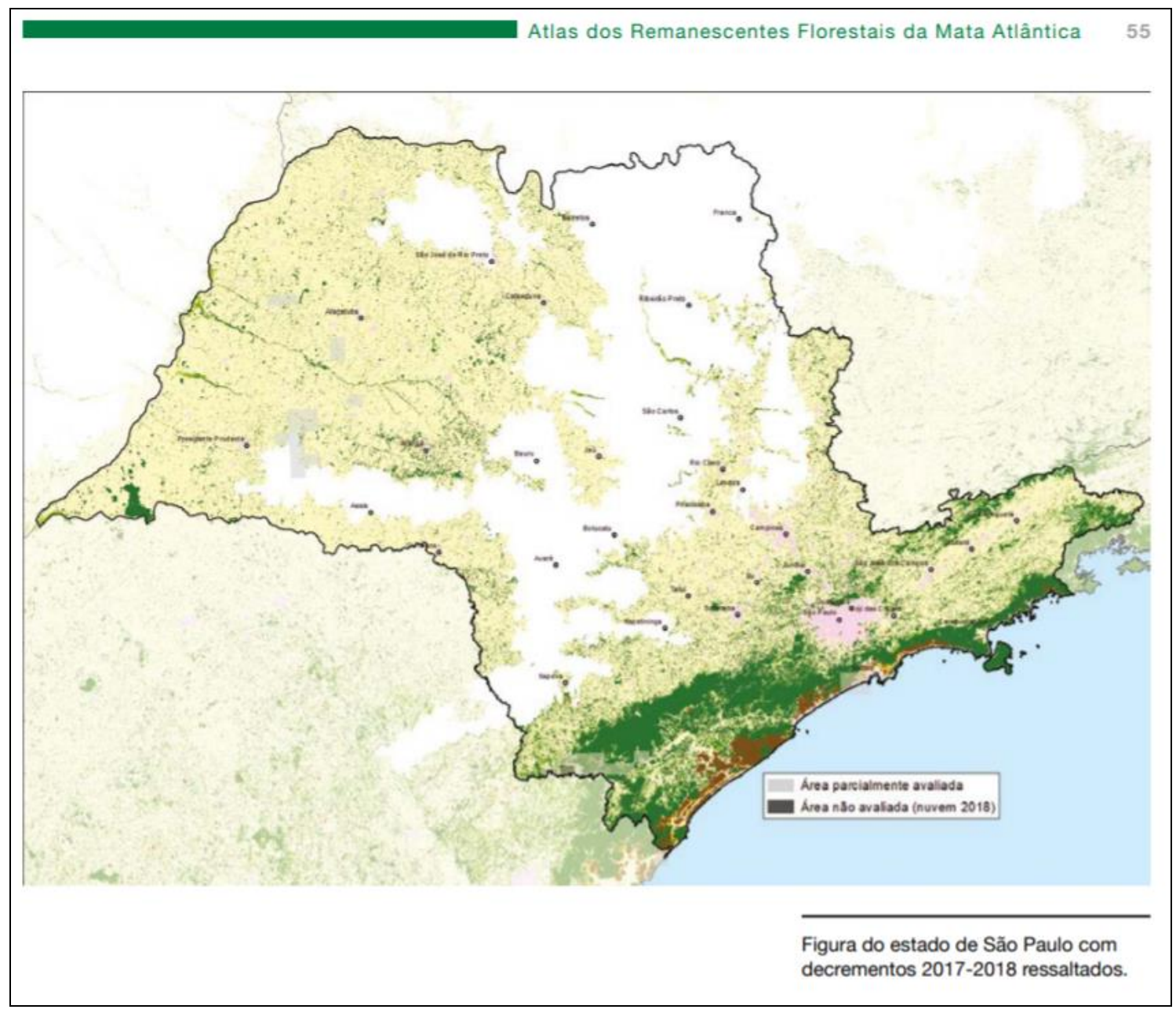

Fonte: Atlas dos Remanescentes Florestais da Mata Atlântica (SOS Mata Atlântica) Relatório Técnico 2017-2018

\subsection{2 - Políticas de Recursos Hídricos e Mudanças Climáticas}

As mudanças climáticas também se somam aos desafios para a conservação e preservação do território paulista. As áreas com plantações de cana-de-açúcar estão suscetíveis aos aumentos de temperatura previstos para as próximas décadas; as regiões litorâneas, sobretudo municípios com vocações turísticas (Santos, São Vicente, Caraguatatuba, Ubatuba e Ilhabela), requerem adaptações mais consistentes frente ao aumento do nível do mar (ARTAXO, 2019) - segundo o IPCC (2014), neste século, o aumento do nível do mar pode alcançar entre $50 \mathrm{~cm}$ a $70 \mathrm{~cm}$. Setores da infraestrutura, como saneamento básico, gestão dos recursos hídricos e drenagem, têm desafios peculiares com as alterações no padrão de chuvas e o aumento de temperatura ao longo dos próximos anos; o risco ao abastecimento hídrico para a população é agravado principalmente para grandes cidades do 
estado, como as que compõem a Região Metropolitana de São Paulo, com a intensidade destes eventos extremos (ARTAXO, 2019).

O estado de São Paulo é o primeiro estado brasileiro a planejar os recursos hídricos por meio de uma Política Estadual, que instituiu o Sistema Integrado de Gerenciamento de Recursos Hídricos, mediante a Lei $n^{\circ}$ 7.663, de 1991. Desde 1993, o estado conta com o Fundo Estadual de Recursos Hídricos (FEHIDRO) por meio da Lei $n^{\circ} 7.663$, de 30 de dezembro de 1991, e regulamentado pelo Decreto $\mathrm{n}^{\circ} 37.300$, de 25 de agosto de 1993, alterado pelo Decreto $n^{\circ} 48.896$, de 26 de agosto de 2004. Dois órgãos públicos também foram criados de maneira permanente a fim de gerenciar os recursos hídricos para múltiplos usos, são eles: Departamento de Água e Energia Elétrica (DAEE), criado pela Lei n ${ }^{\circ} 1.350$, de 12 de dezembro de 1951, complementada pela Lei $\mathrm{n}^{\circ}$ 7.663/1991 e a Companhia Ambiental do Estado de São Paulo (CETESB), criada pela Lei no 118 de 29 de junho de 1973, alterada pela Lei $n^{\circ} 13.542 / 09$.

Já quanto à questão climática, o planejamento estadual perpassa mecanismos legislativos, ou criação de fóruns, como podem ser vistos na linha histórica reproduzida a seguir:

I. Em 1995, há a criação do Programa Estadual de Mudanças Climáticas Globais em que é instituído um Grupo de Trabalho que, posteriormente, dá origem ao Programa Estadual de Mudanças Climáticas do Estado de São Paulo (PROCLIMA) e ao Programa Estadual de Proteção à Camada de Ozônio (PROZONESP);

II. Em 2005, há a criação do Fórum Paulista de Mudanças Climáticas Globais e de Biodiversidade, pelo Decreto Estadual No 49.369;

III. Em 2009, há a instituição da Política Estadual de Mudanças Climáticas (PEMC), pela Lei $N^{\circ} 13.798$, de 2009;

IV. Em 2011, surge o Programa Estadual de Prevenção de Desastres Naturais e de Redução de Riscos Geológicos, pelo Decreto No 57.512;

IV. Em 2016, há a criação do Grupo Gestor do Plano Estadual da Agricultura de Baixo Carbono, a internalização paulista do Plano Setorial de Mitigação e de Adaptação às Mudanças Climáticas para a Consolidação de uma Economia de Baixa Emissão de Carbono na Agricultura, abreviado como Plano ABC;

VI. Em 2019, o estado de São Paulo cria o Acordo Ambiental São Paulo, que visa unir empresas e setor público, voluntariamente, para cumprir metas de redução 
de emissão de gases de efeito estufa, assegurar a eficiência hídrica e energética.

Na PEMC, em específico, existe o Protocolo Climático do Estado de São Paulo, iniciativa introduzida pelo Governo do Estado de São Paulo na $21^{\mathrm{a}}$ Conferência das Partes da Convenção das Nações Unidas sobre Mudanças Climáticas (COP), realizada em Paris, França, em 2015. O Protocolo parte de ações voluntárias de empresas que se comprometem a reduzir emissões de gases de efeito estufa e adotar ações de adaptações às mudanças climáticas. O compromisso assinado pelo Estado de São Paulo envolve uma redução de até $20 \%$ de emissões de dióxido de carbono $\left(\mathrm{CO}_{2}\right)$ até 2020, comparados aos níveis de 2005 (NEDER, 2019). Inclusive, a participação do governo paulista em COPs data também da COP-15, realizada em Copenhague, na Dinamarca, em 2009, em que a SABESP assinou o manifesto "Seal the Deal", no qual são apresentadas metas de redução de emissão de carbono, além de iniciativas de geração de energia própria nas estações de tratamento de água e esgoto $^{41}$. Ainda dentro do âmbito do PEMC, há o Zoneamento Ecológico Econômico (ZEE), instituído em 2010, com acompanhamento de grupo interdisciplinar, que busca ferramentas para, dentre vários objetivos, alcançar: a) Resiliência a Segurança Hídrica; e b) Resiliência às Mudanças Climáticas.

Em publicações recentes, o governo do Estado de São Paulo apresentou o relatório "Mudanças Climáticas: Balanços e Recomendações", em 2018, com resultados e recomendações para que o estado paulista cumpra com a PEMC, sugerindo que o governo estadual se aproxime dos governos locais; e em 2019, apoiou institucionalmente o lançamento da publicação "Planejando o Futuro Hoje: ODS 13, Adaptação e Mudanças Climáticas em São Paulo", produzida pelo Instituto de Energia e Ambiente da Universidade de São Paulo (USP), com a colaboração de dezena de autores acadêmicos e técnicos. A publicação tem como objetivo fazer um panorama do estado de São Paulo acerca das mudanças climáticas, dos planos de adaptações, políticas públicas pelas regiões, eventos extremos e a participação da sociedade civil.

\subsection{3 - Evento extremo climático - Seca de 2013-2015}

São Paulo apresenta uma diversidade climática tendo em vista seu relevo acidentado, posição geográfica e as diferentes influências de massas de ar (ROLIM et al, 2007).

\footnotetext{
${ }^{41}$ Este item, além de outros, é analisado com mais detalhes no Capítulo 4
} 
Historicamente, no estado paulista, os desastres relacionados aos eventos extremos têm relações com a chuva, com ocorrência de inundações e deslizamentos provocados em dias de alta precipitação, atingindo, sobretudo, as regiões mais adensadas, provocando danos para a população (AMBRIZI et al., 2019).

Entre os episódios climáticos, ganha destaque a seca de 2013-2015, que atingiu fortemente o estado de São Paulo e ganhou notoriedade midiática, provocando reações diretas nos âmbitos sociais e econômicos da região (DI GIULIO et al., 2017). Esse evento climático e seus impactos tiveram reverberações também nas discussões sobre as mudanças climáticas e eventos extremos no país (JACOBI, 2015).

MARENGO et al. (2015) mostram que entre os impactos da estiagem prolongada na Região Metropolitana de São Paulo (RMSP), houve o desabastecimento de água de regiões periféricas, devido aos problemas de captação dos mananciais, além do impacto econômico ocasionado por aumento da tarifa da energia elétrica (dependente exclusivamente da disponibilidade hídrica) e a diminuição da produção industrial durante o período.

O comportamento climático observado no período foi de volume de chuvas inferior à média histórica e aumento das temperaturas máximas; as bacias hidrográficas que contribuem com os sistemas produtores de água, como Cantareira e Paraíba do Sul, tiveram uma vazão abaixo da média histórica (MARENGO et al., 2015). Pelos estudos realizados por MARENGO et al. (2015), o verão de 2014 foi o mais seco, desde 1962; o baixo volume de chuvas observado em 2013, acentuado em 2014, principalmente na região em que o Sistema Cantareira se encontra, causou impacto para o armazenamento de água para a população paulista. As ocorrências de seca prolongadas já ocorreram em outras épocas, mas em menor intensidade e menor duração (AMBRIZZI et al., 2019), como podem ser observadas abaixo no Quadro 5: 
Quadro 5 - Evento extremo relacionado à seca no estado de São Paulo

\begin{tabular}{|c|c|c|}
\hline $\mathbf{U F}$ & $\begin{array}{c}\text { Ocorrência de evento } \\
\text { extremo relacionado à seca nos } \\
\text { últimos anos }\end{array}$ & $\begin{array}{l}\text { Evento extremo relacionado à } \\
\text { seca de maior duração registrado }\end{array}$ \\
\hline $\begin{array}{l}\text { São } \\
\text { Paulo }\end{array}$ & $\begin{array}{l}\text { Secas em 1953, 1971, 2001, } \\
2013 \text { (MARENGO, et al., 2015; } \\
\text { AMBRIZI et al., 2019) }\end{array}$ & $\begin{array}{l}\text { Seca de 2013-2015 (MARENGO, } \\
\text { et al., 2015; AMBRIZI et al., 2019), com } \\
\text { foco na RMSP. }\end{array}$ \\
\hline
\end{tabular}

Fonte: Elaborado pelo autor

Na região Sudeste como um todo, as chuvas têm ciclos anuais bem definidos: entre dezembro e março (verão) os volumes são altos, e nos meses subsequentes (outono e inverno) os volumes são menores, com destaques para julho-agosto (inverno) (MARENGO et al., 2015).

Os dados das variações do clima de 1980 a 2015 de XAVIER et al. (2015) no estado de São Paulo mostram que é possível identificar um acréscimo na temperatura e uma diminuição da precipitação acumulada anual ao longo dessas décadas. Os dados do Gráfico 2 evidenciam os achados para o estado de São Paulo: 
Gráfico 2 - Série histórica de variações do clima

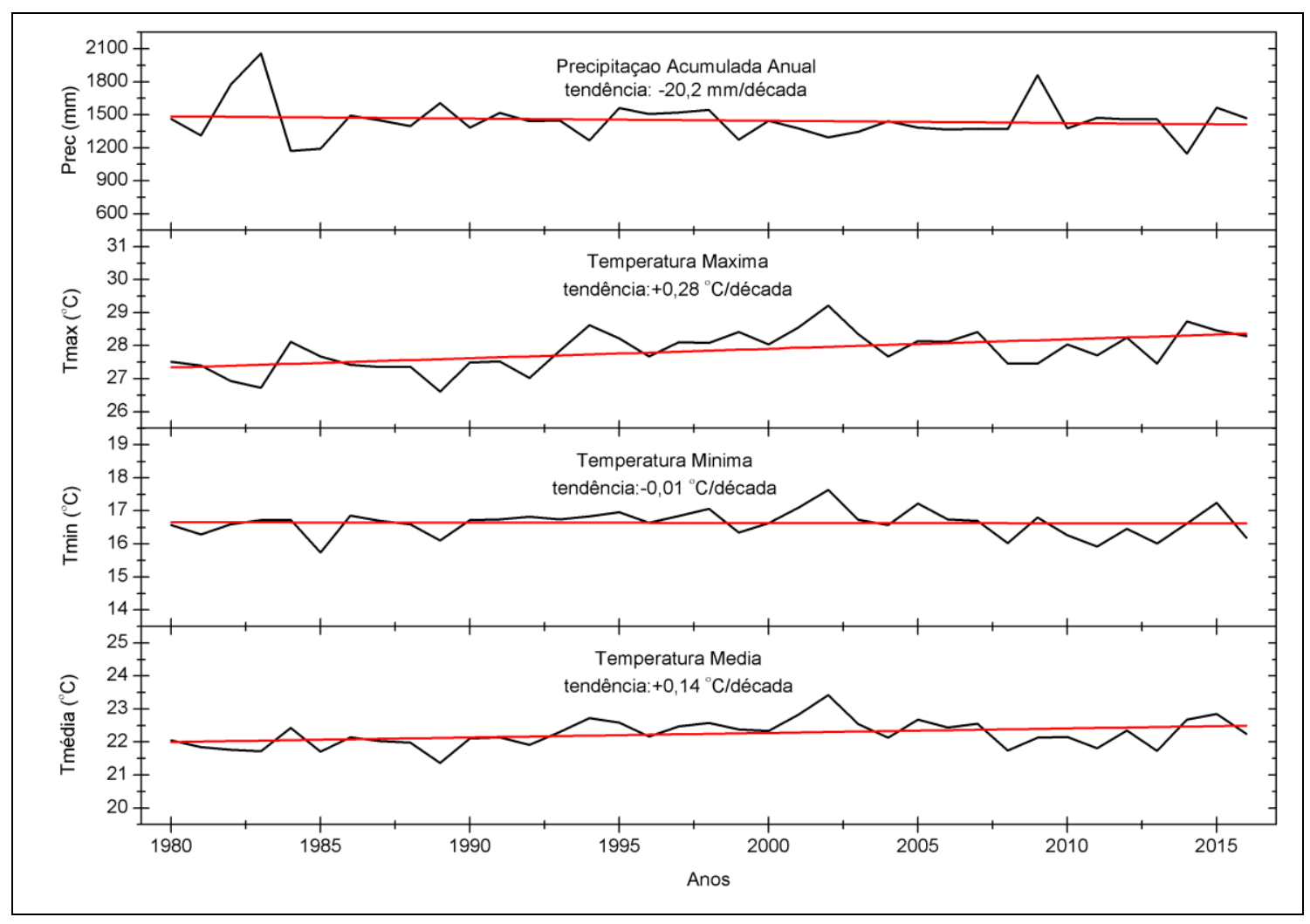

Fonte: Dados extraídos do banco de dados meteorológicos (XAVIER et al., 2017)

É possível aferir que houve uma queda de 70,7 mm referente às chuvas nas três décadas e meia de análise; no mesmo período, foi possível observar um aumento da temperatura máxima de $0,98^{\circ} \mathrm{C}$; uma diminuição de $0,35^{\circ} \mathrm{C}$ na temperatura mínima; e um aumento de $0,49^{\circ} \mathrm{C}$ na temperatura média. Estas aferições evidenciam, portanto, que o clima no estado de São Paulo está sofrendo alterações gradativas; o futuro climático do estado de São Paulo é incerto, uma vez que o norte do estado pode sofrer com secas mais intensas, e o sul do estado pode ter um aumento de chuvas nas próximas décadas (ARTAXO, 2019). Estudos mostram que a Região Sudeste da América do Sul tendem a sofrer com mais volumes de chuvas de 2021 até 2100 , com possíveis aumentos de $25 \%$ a $30 \%$ até o final do século (AMBRIZI et al. 2012; MARENGO et al., 2011), sobretudo atingindo São Paulo (PMBC, 2014a). No Quadro 6 são apresentadas as projeções climáticas para o estado de São Paulo, com base na literatura: 
Quadro 6 - Projeções climáticas para o estado de São Paulo

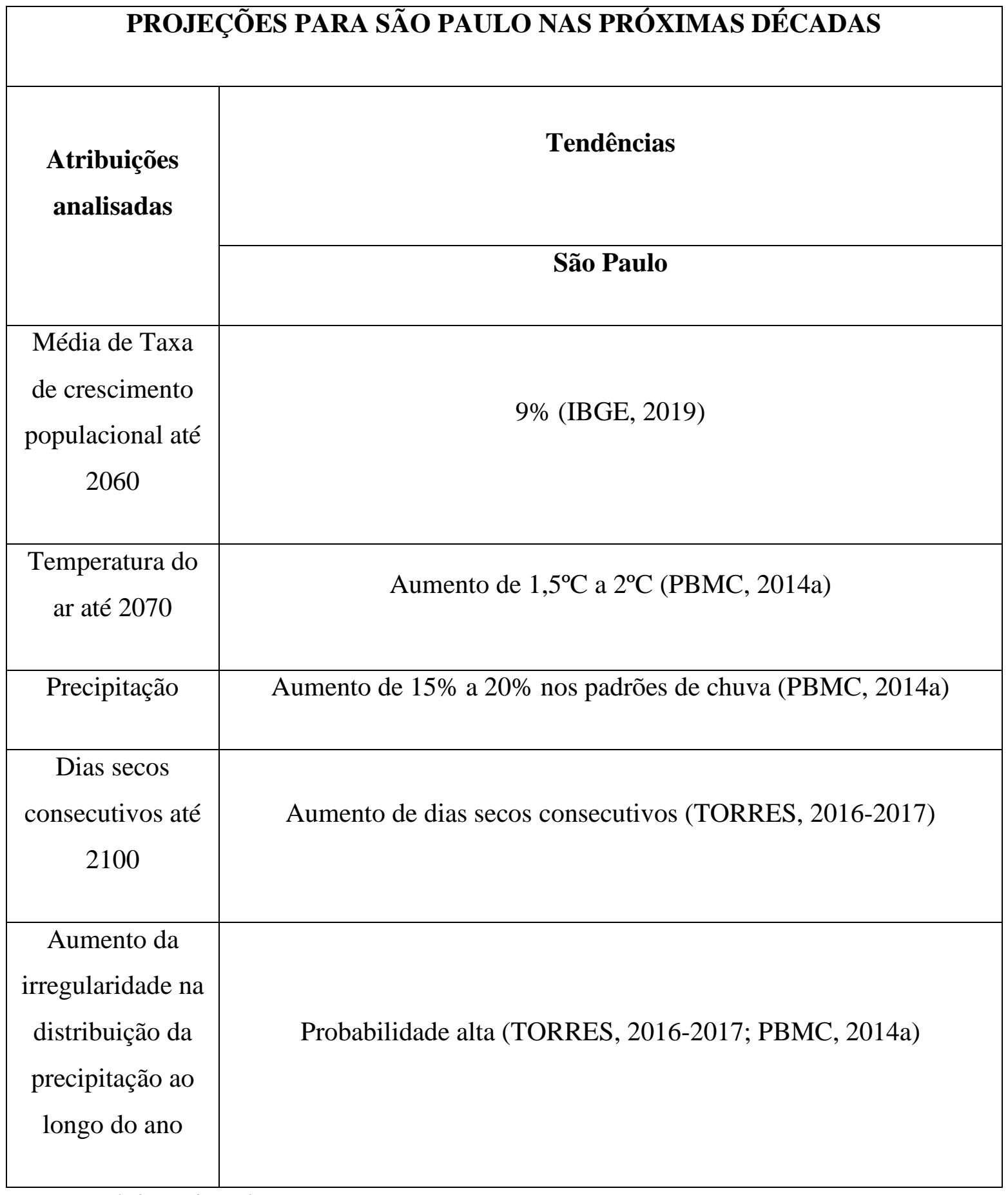

Fonte: Elaborado pelo autor

\subsection{4 - Mudanças climáticas e o setor de Saneamento de São Paulo}

O estado paulista foi o primeiro a criar uma política estadual de saneamento básico, por meio da Lei 7.750 de 1992, para estabelecer planejamento, programas e atividades sobre os municípios do estado. A Lei Complementar 1.025 de 2007 dispõe da criação do Conselho 
Estadual de Saneamento Básico (CONESAN), que tem, entre outras finalidades, a discussão e aprovação do Plano Plurianual de Saneamento e do Plano Executivo Estadual de Saneamento, encaminhando-as ao Governador.

Estima-se que dos 645 municípios paulistas, mais de 55\% sejam operados pela Sabesp; $40 \%$ pelas autarquias/departamentos/secretarias municipais; e 5\%, ou menos, pelas companhias privadas (BRASIL, 2019). A ARSESP é responsável por regular 323 municípios atendidos pela Sabesp, além de três municípios com serviços prestados por empresas privadas: Mairinque (Saneaqua), Santa Gertrudes (BRK Ambiental) e Cabrália Paulista (Águas de Cabrália) $^{42}$. Atualmente, a Secretaria de Meio Ambiente e Infraestrutura (SIMA) é o ente estadual responsável por auxiliar os municípios não atendidos pela Sabesp nos planejamentos, investimentos e execução do saneamento básico, além de ter a Sabesp no organograma como uma das empresas de responsabilidade da secretaria.

A Sabesp é uma sociedade anônima de economia mista, com ações nas Bolsas de Valores de São Paulo (BOVESPA) e Bolsas de Valores de Nova Iorque (NYSE), cujo controlador majoritário ainda é o Estado de São Paulo. Dentre os direitos que a Sabesp garante aos acionistas estão o direito ao dividendo mínimo obrigatório sobre o lucro líquido de cada exercício social; o direito a voto pleno; o direito a reembolso de capital; e o direito de preferência para subscrever ações, partes beneficiárias conversíveis em ações, debêntures conversíveis em ações e bônus de subscrição ${ }^{43}$.

No Brasil, a Sabesp é a maior empresa de saneamento básico, e representa $1 / 3$ dos investimentos de saneamento básico no Brasil, contudo os indicadores de acesso aos serviços de saneamento básico em todo o estado paulista variam, inclusive as perdas de água, conforme mostra o Tabela 7:

\footnotetext{
${ }^{42}$ http://www.arsesp.sp.gov.br/SitePages/saneamento/informacoes-tecnicas.aspx acessado em 09 de fevereiro de 2020

${ }^{43}$ https://br.advfn.com/bolsa-de-valores/bovespa/sabesp-on-SBSP3/cotacao acessado em 09 de fevereiro de 2020
} 
Tabela 7 - Investimentos realizados e indicadores de acesso ao abastecimento de água e esgotamento sanitário pelo estado de São Paulo de 2011 a 2018 (BRASIL, 2018; BRASIL, 2017; BRASIL, 2016; BRASIL, 2015; BRASIL, 2014; BRASIL, 2013; BRASIL 2012;

BRASIL 2011)

\begin{tabular}{|c|c|c|c|c|c|}
\hline $\begin{array}{l}\text { ANO DE } \\
\text { REFERÊNCIA }\end{array}$ & $\begin{array}{c}\text { IN } 055 \text { - } \\
\text { Índice de } \\
\text { atendimento } \\
\text { Total de } \\
\text { Água (\%) }\end{array}$ & $\begin{array}{l}\text { IN } 056 \text { - } \\
\text { Índice de } \\
\text { atendimento } \\
\text { total de } \\
\text { esgoto } \\
\text { referido aos } \\
\text { municípios } \\
\text { atendidos } \\
\text { com água } \\
(\%)\end{array}$ & $\begin{array}{c}\text { IN } 046 \text { - } \\
\text { Índice de } \\
\text { Esgoto } \\
\text { Tratado } \\
\text { referido à } \\
\text { Água } \\
\text { Consumida } \\
\quad(\%)\end{array}$ & $\begin{array}{l}\text { IN } 049 \text { - } \\
\text { Indice de } \\
\text { Perdas na } \\
\text { Distribuiçã } \\
\quad \text { o (\%) }\end{array}$ & $\begin{array}{c}\text { Investimentos } \\
\text { realizados em } \\
\text { água e } \\
\text { esgotamento } \\
\text { sanitário (R\$ } \\
\text { bilhões) }\end{array}$ \\
\hline 2011 & 95,70 & 86,70 & 49,10 & 35,2 & $3.159,1$ \\
\hline 2012 & 96 & 87,40 & 51,90 & 34,2 & $3.325,8$ \\
\hline 2013 & 95,90 & 87,40 & 53 & 34,3 & $3.476,0$ \\
\hline 2014 & 95,80 & 88 & 55,90 & 33 & $4.076,4$ \\
\hline 2015 & 95,60 & 88,40 & 61,30 & 33,5 & $4.193,5$ \\
\hline 2016 & 95,80 & 88,80 & 62,90 & 36,1 & $4.505,3$ \\
\hline 2017 & 96,20 & 89,70 & 64,70 & 35,3 & $4.035,6$ \\
\hline 2018 & 96,19 & 89,82 & 64,48 & 34,1 & $5.018,3$ \\
\hline
\end{tabular}

Fonte: Elaborado pelo autor

Nota-se que os índices de tratamento de esgoto e de perdas de água no estado de São Paulo são os maiores desafios em relação à gestão do saneamento básico. Um dos exemplos de ainda não ter $100 \%$ do volume de esgoto tratado é o impacto nas águas dos afluentes (PAGANINI, 2007), como no rio Tietê, um dos afluentes mais importantes do país, cruzando 62 municípios, sendo quase todos do estado de São Paulo, desaguando no rio Paraná, na divisa com o estado de Mato Grosso do Sul. É importante destacar que esgotos tratados também podem gerar eutrofização das águas caso os nutrientes nitrogênio e fósforo não sejam removidos nos processos de tratamento (VON SPERLING et al., 2009), todavia o não tratamento é mais danoso à qualidade das águas, sobretudo quando há uma discrepância da 
carga orgânica gerada versus carga orgânica remanescente nos corpos d’água. Já o volume de água perdido constantemente representa uma perda significativa do recurso natural para o abastecimento de água e, no caso do estado de São Paulo, este item se torna mais evidente a partir da seca prolongada entre 2013-2015. Esta seca, que resultou na crise hídrica no estado, sobretudo na RMSP, colocou luz aos problemas de eficiência das empresas de saneamento, não só em São Paulo, e a questão do consumo de água foi um dos itens mais discutidos durante o período (LEITE, 2018).

Os recursos hídricos estiveram no centro das discussões com destaque para os discursos institucionais de órgãos relacionados ao gerenciamento hídrico, que tiveram protagonismo na condução do problema no estado paulista. LEITE (2018, p. 135), ao analisar o gerenciamento do discurso hídrico na RMSP no período de 2013-2015, com base em análises discursivas dos atores responsáveis diretamente pelo gerenciamento dos sistemas hídricos da região (concessionária estadual de água e esgotos, SABESP; e Governo do Estado de São Paulo Gesp), identifica que:

"A Sabesp e o Gesp construíram uma versão da crise de abastecimento hídrico cuja deflagração foi devida unicamente ao comportamento climático registrado durante o biênio 2014-2015, obliterando discussões a respeito de medidas prévias e adoção de políticas públicas que poderiam ter minimizado seus efeitos".

O Governo do Estado de São Paulo, por meio da ARSESP, adotou medidas de racionamento como (i) redução de fluxo de água para algumas regiões das cidades; (ii) campanhas educativas para diminuição do consumo de água; (iii) e medidas tarifárias que incluía bônus e ônus conforme os consumos mensais (SCHAPIRO, 2018). Toda a discussão em torno da tarifa ganhou mais capítulos com um pedido da Sabesp para rever o reequilíbrio econômico-financeiro frente ao contrato de prestação de serviço, justificando que o consumo de água teria diminuído durante o período da seca prolongada. Em 2015, a tarifa sofreu ajustes de $15 \%$, após autorização da $\operatorname{ARSESP}^{44}$, sobre o argumento de que a empresa não tinha responsabilidade sobre a crise hídrica (SCHAPIRO, 2018).

Em 2015, a Sabesp, por meio do documento "Crise Hídrica, Estratégia e Soluções" (SÃO PAULO, 2015), divulgado à sociedade, reforçou que não era previsto uma afluência tão

\footnotetext{
${ }^{44}$ http://g1.globo.com/sao-paulo/noticia/2015/05/agencia-estabelece-reajuste-de-1524-nas-tarifas-da-sabesp.html acessado em 09 de fevereiro de 2020
} 
abaixo do normal, como aconteceu de 2013 a 2015; desta forma, as obras previstas para dali em diante eram de reforço de sistema produtor de água, deixando em segundo plano os esforços em prol do esgotamento sanitário. A desconfiança por parte das organizações nãogovernamentais em relação aos indicadores de cobertura de saneamento básico, bem como os acontecimentos durante a seca de 2013-2015 referentes ao abastecimento de água pelo governo de São Paulo, resultaram na criação da coalização de 60 entidades do Terceiro Setor nomeada de Aliança Pela Água (JACOBI et al., 2015). Esta iniciativa buscou fortalecer o diálogo entre sociedade civil e governos (municipais e estadual), em busca de soluções conjuntas para o abastecimento hídrico no estado de São Paulo, sobretudo na RMSP.

Anos antes, em 2009, como foi mostrado no capítulo anterior, o Governo do Estado de São Paulo, por meio da Sabesp, reconhecendo as mudanças climáticas como uma ameaça, assinou o acordo na COP-15 na redução de gases poluentes na atmosfera. Na edição seguinte, na COP-16, em Cancun (México), o Governo do Estado de São Paulo, mais uma vez representado pela Sabesp, apresentou os problemas causados pelo volume de chuva concentrado em 2009, danificando as ETAs de Franca e Campo Limpo; além disso, os ciclos instáveis de chuvas também foram apresentados como preocupação da empresa ${ }^{45}$.

${ }^{45} \mathrm{http} / / /$ site.sabesp.com.br/uploads/file/asabesp_doctos/COP16_portugues.ppt acessado em 09 de fevereiro de 2020 


\section{CAPÍTULO 4 - RESULTADOS}

Este capítulo discorre sobre os resultados obtidos a partir da análise dos Relatórios de Sustentabilidade e de Gestão e das transcrições das entrevistas semiestruturadas realizadas com os atores sociais, conforme abordado no capítulo de Metodologia. Particularmente sobre as percepções dos atores entrevistados, os resultados são apresentados em três eixos analíticos: mudanças climáticas, riscos dos impactos das mudanças climáticas e riscos desses impactos ao setor de saneamento básico. Da terceira categoria analítica, emergiram duas subcategorias (ou categorias mais específicas), focadas particularmente na questão de saneamento, cujos resultados apresentados neste capítulo incluem percepções dos atores sobre o preço da água e ineficiência da gestão das empresas de saneamento básico frente às mudanças do clima.

\section{1 - RELATÓRIOS DE SUSTENTABILIDADE E DE GESTÃO DE 2012 A 2018 - CAGECE E SABESP}

Nos documentos analisados da Cagece e da Sabesp, buscou-se identificar como as mudanças climáticas são abordadas nos relatórios de sustentabilidade publicados entre 2012 e 2018, períodos estes que ambos os estados enfrentaram situações similares de estiagem prolongada, com destaque maior para a duração no Ceará (SILVEIRA et al., 2018). CAMPOS et al. (2013) explicam que estes relatórios de sustentabilidade têm como objetivo mostrar as atividades das empresas em torno da sustentabilidade, assim como divulgar os riscos e oportunidades. É por meio destes documentos que investidores e acionistas podem se basear na compra e venda de ações, uma vez que os relatórios de sustentabilidade podem conter informações estratégicas da empresa, tanto do presente, quanto do futuro. Mesmo que os relatórios ainda sejam feitos de maneira voluntária pelas empresas, não é possível, com base em seus conteúdos, aferir a efetividade das políticas de sustentabilidade adotadas.

Assim, ao considerar estes apontamentos, os resultados acerca da leitura dos relatórios de ambas as companhias de saneamento, apresentados a seguir, visam identificar se estes documentos abordam o tema das mudanças climáticas, aferindo duas questões norteadoras:

a) Como as mudanças climáticas aparecem nos relatórios de sustentabilidade das instituições estudadas;

b) Como as mudanças climáticas são relacionadas aos riscos pelas companhias estaduais. 


\subsection{1 - Cagece - Ceará}

Anteriormente a 2017, a Cagece não publicava Relatórios de Sustentabilidade. Assim, foi analisado o Relatório de Gestão de 2015 a 2018 para investigar as indagações propostas nesta dissertação. Com 320 páginas, os termos relacionados com eventos extremos, tais como seca e estiagem, são mencionados no relatório 107 vezes, em contextos variados. Estes termos são citados no documento, ao tratar do período de 2012 a 2018, e usados para justificar as decisões para investimentos em infraestrutura, projetos de eficiência e aumento da tarifa. A estiagem abre o documento, no texto assinado pelo Governador do Estado do Ceará, que faz menção aos seis anos de estiagem prolongada no estado cearense. No capítulo "Tecnologia, Inovação e Olhar para o Futuro", a palavra é associada a ações mitigadoras e adaptativas, tais como: i. combate aos desperdícios pela companhia estadual de saneamento; ii. construção de usina de dessalinização na Região Metropolitana de Fortaleza.

O documento conta com entrevistas feitas com diretores e presidente da companhia durante a gestão de 2015 a 2018. Nos momentos em que os termos citados acima são mencionados, sobretudo a seca, existe uma associação direta com a escassez de água, até mesmo pelo aspecto geográfico do território do estado. Nas entrevistas com os diretores, divulgadas no Relatório, quando o período de estiagem de 2012 a 2018 é mencionado, os mesmos reconhecem que esta é a maior seca da história do estado e associam as ações da Cagece em assegurar mais recurso hídrico para a população, citando diversas obras realizadas pelo Governo do Estado do Ceará durante o período. Elas são divididas por ano; desta forma é possível identificar as seguintes obras:

2015:

Ampliação e implantação do sistema de esgotamento sanitário de Maranguape;

Melhorias Sanitárias Domiciliares (MSD) nas localidades de São Chico, Cajazeiras e Cacimba Funda em Aracati;

Implantação do sistema de abastecimento de água na localidade de Macaoca em Madalena;

Ampliação do sistema de esgotamento sanitário de Fortaleza na sub-bacia SD6; Ampliação do sistema de esgotamento sanitário na sub-bacia SE2 em Fortaleza 2016: 
Serviços de MSD em Aracati e Fortim, nas localidades de Guajiru, Jirau, Outeiro,

Tábua Lascada, Santa Tereza e Córrego dos Fernandes;

Ampliação do sistema de abastecimento de água de Capistrano;

Ampliação do sistema de abastecimento de água da cidade de Cascavel;

Instalação e teste dos serviços de pressurização através de captação em 10 unidades

flutuantes da ETA Gavião em Pacatuba;

Implantação do sistema de abastecimento de água em Giqui, Jaguaruana;

Implantação do sistema de abastecimento de água no Sítio Pau D’arco, Russas;

Implantação do sistema de abastecimento de água no distrito de Mineiro, em Nova

Jaguaribara;

Ampliação dos sistemas de abastecimento de água das localidades de Barra do Sitiá e

Panamá em Banabuiú;

Serviços de MSD em Russas, nas localidades de Ramal das Flores, Miguel Pereira do

Mauro e Miguel Pereira;

2017:

Implantação do sistema de abastecimento de água de Ramal das Flores, Russas;

Ampliação dos ramais principal e norte do sistema adutor da região da Serra da

Ibiapaba;

Recuperação da adutora de água bruta de Irajá em Hidrolândia;

Instalação do sistema de abastecimento de água nas localidades de Batente e Arisco dos

Marianos em Ocara;

Obras componentes do emissário efluente do Complexo Industrial e Portuário do Pecém (CIPP) em São Gonçalo do Amarante;

Instalação de uma adutora emergencial com quase $12 \mathrm{~km}$ para o abastecimento de água de Aquiraz.

2018:

Ampliação do sistema de esgotamento sanitário de Fortaleza na região das sub-bacias CD1, CD2 e CD3, margem direita do rio Cocó, região da Água Fria;

Implantação do sistema de esgotamento sanitário da localidade de Capitão Mor, em Pedra Branca;

Melhorias sanitárias domiciliares (MSD) nas localidades de Borges, Giqui, Peixes e

Sítio Pau D’arco, em Russas e Jaguaruana;

Ampliação do serviço de abastecimento de água de Caridade; 
Ampliação do sistema de esgotamento sanitário de Fortaleza - Macrossistema;

Implantação do sistema de abastecimento de água na sede do município de Ibaretama;

\section{OBRAS EM EXECUÇÃO OU COM CONTRATOS EM ANDAMENTO:}

Planta de dessalinização da água marinha para complementar o abastecimento da

Região Metropolitana de Fortaleza

Outras obras apareceram com contrato em andamento, assim como edital em elaboração ou licitação, ou atividades preparatórias.

Destaca-se neste Relatório de Gestão o capítulo que discorre sobre "A Convivência com Seca no Interior", no qual é detalhado o Grupo de Contingência, constituído de uma dezena de órgãos públicos do estado, responsável pelo mapeamento dos municípios que sofreram com a estiagem. Esse grupo caracteriza a seca como uma condição do Ceará (LINDOSO, 2013). No entanto, embora a seca seja reconhecida do ponto de vista de convivência, o Relatório de Gestão cita a expressão "combate à estiagem", citando novamente as obras hídricas como instrumento de confronto a esta condição de clima. A análise do documento sugere que a Cagece reconhece que as perdas de água no sistema de distribuição contribuem para a deficiência hídrica do estado, já que há menção ao combate às perdas de águas com a implantação de novas tecnologias e modelos de fiscalização como um fator condicionante para amenizar os impactos das estiagens.

Já a análise do primeiro Relatório de Sustentabilidade da Cagece, referente ao ano de 2017, evidencia que os mesmos termos analisados no documento anterior referente aos eventos extremos aparecem sete vezes. O documento é menos denso, com 45 páginas, e faz menções similares ao Relatório de Gestão de 2015 a 2018 em relação ao evento de seis anos de seca prolongada, com medidas de obras hídricas para mitigar os efeitos causados pela estiagem prolongada.

Em relação às atividades de sustentabilidade da empresa, o documento menciona uma única vez as condições climáticas, colocadas como indicativo de atenção com a preservação da água no futuro. Ainda no Relatório de Sustentabilidade analisado, a Cagece destaca a medida tarifária aplicada aos consumidores em decorrência da seca prolongada - a tarifa de contingência foi instituída, onerando os clientes que consumirem mais água. Esta medida foi aprovada tanto pela Arce, quanto pela Arcfor. 
No documento, a empresa lança mão de objetivos e metas referentes à porcentagem da população que será atendida até 2022 com serviços de água e esgotamento sanitário, sendo 98,69\% no primeiro; e 45,78\% no segundo. Estes esforços são mostrados ao lado do compromisso da empresa com os ODS, em que a Cagece é signatária, particularmente com os objetivos relacionados às mudanças climáticas e acesso à água.

Para elucidar os achados, o Quadro 7 traz uma síntese dos principais elementos identificados no documento

Quadro 7 -Achados nos Relatórios de Sustentabilidade e Relatório de Gestão da Cagece

\begin{tabular}{|l|l|}
\hline \multicolumn{1}{|c|}{ Principais tópicos } & \multicolumn{1}{c|}{ Conteúdos identificados } \\
\hline Aborda as Mudanças Climáticas ou eventos & $\begin{array}{l}\text { Mudanças climáticas ou eventos extremos } \\
\text { climáticos não são citados explicitamente; } \\
\text { contudo, os termos "secas" e "estiagem" são } \\
\text { frequentes nos dois documentos. }\end{array}$ \\
\hline $\begin{array}{l}\text { Vislumbra metas estratégicas de negócios } \\
\text { que consideram as Mudanças Climáticas? }\end{array}$ & $\begin{array}{l}\text { Todas as ações conectadas às secas são obras } \\
\text { de infraestrutura cinza, com interligação de } \\
\text { açudes e construção de novos modelos de } \\
\text { reservação. A dessalinização na Região } \\
\text { Metropolitana de Fortaleza surge como } \\
\text { resposta da empresa às secas, mas sem fazer } \\
\text { menções às Mudanças Climáticas. }\end{array}$ \\
\hline
\end{tabular}

Fonte: Elaboração do autor

\subsection{2 - Sabesp - São Paulo}

Ao analisar os Relatórios de Sustentabilidade de 2012 a 2018 da Sabesp, é possível fazer uma distinção entre (i) período anterior à estiagem intensa, isto é, 2012; (ii) período durante a estiagem, 2013 a 2015; e (iii) período pós estiagem, considerado pela própria companhia, de 2016 a 2018.

No primeiro período, os termos relacionados a eventos extremos, como inundações, enchentes, secas e/ou estiagens, não aparecem na maioria dos capítulos - os termos secas e estiagens aparecem oito vezes. Em relação às mudanças climáticas, o documento da 
companhia reconhece os possíveis danos pela alteração do clima ao sistema de água e esgotamento sanitário, sobretudo em relação à escassez hídrica, em que é citado o projeto Aquapolo, de reúso de água para a indústria, na região do $\mathrm{ABC}$ paulista, bem como os projetos de redução de perdas de água, com investimentos altos para este item em específico. As mudanças climáticas são novamente citadas ao referenciar os investimentos necessários para o futuro (p. 37):

"Sob o aspecto financeiro, um desafio bastante
relevante para o setor reside em assegurar recursos
suficientes para universalizar os serviços com
qualidade e para garantir a segurança do
abastecimento de água, atualmente ainda mais
pressionado pela poluição, pela ocupação
desordenada do solo e pelas mudanças climáticas,
que podem aumentar a necessidade de investimentos".

Ainda no primeiro período analisado, as mudanças climáticas são abordadas em um capítulo específico para tratar da gestão de emissão de gases de efeitos estufa. Nele, a companhia esclarece quais medidas adotou para a diminuição de $\mathrm{CO}_{2}$ na atmosfera, como renovação de frotas de carros com tecnologia flex e redução no consumo de energia nas estações de tratamento de água e esgoto. Sinaliza também medidas tomadas para contribuir com o meio ambiente, como a plantação de mudas, recuperação de matas ciliares, recuperação de rios, programas de educação ambiental, projetos de reciclagem, entre outros programas de incentivo de redução do uso da água em prédios públicos do estado.

Neste documento há um capítulo intitulado "Segurança no Abastecimento de Água em um Cenário de Escassez Hídrica", que discorre sobre as dificuldades de disponibilidade hídrica na RMSP. "Nem todos sabem, mas em nossos principais mercados temos que lidar com situações de escassez hídrica semelhantes às de regiões desérticas" (p. 19). O relatório faz menções dos investimentos vultosos para abastecimento de água de até $\mathrm{R} \$ 1,3$ bilhão no Programa Metropolitano de Água: Segurança no Abastecimento - 1990 a 2012, e cita o crescimento populacional da RMSP no mesmo período, que foi de $30 \%$ atrelado a $41 \%$ do crescimento de produção de água. A obra de implantação do Sistema Produtor São Lourenço (SPSL) já surge neste relatório com a abertura do edital para aumentar a capacidade de ampliação hídrica em até $4,7 \mathrm{~m}^{3} / \mathrm{s}$ para a RMSP. Para o interior, a Sabesp explicitou no relatório que criou o programa “Água É Vida” para as áreas mais vulneráveis socialmente e que estão afastadas das sedes urbanas, focando em sistemas simplificados de esgotamento sanitário. 
No segundo período analisado, os termos relacionados aos eventos extremos, como inundações, enchentes, secas e/ou estiagens, são citados com mais frequência, principalmente a seca, que surge no contexto da baixa vazão dos mananciais de captação superficial, como o Cantareira, resultando na dificuldade de abastecimento de água para a população. No relatório de 2013, os termos chuva, seca, enchente e estiagem aparecem 34 vezes; o destaque maior é para chuva e seca, que são relacionados ao início da estiagem do estado paulista. No documento de 2014, seca, estiagem e chuva aparecem 52 vezes. No relatório de 2015, os termos chuva, estiagem e seca são encontrados 34 vezes. Em todos os documentos, os contextos dos termos são citados para justificar as ações da companhia em relação aos projetos de engenharia, investimentos em obras e questões tarifárias.

De 2013 a 2015, os documentos trazem mais capítulos em que as mudanças climáticas são citadas mais vezes, ainda que a estiagem prolongada no mesmo período não tenha sido relacionada diretamente com as alterações do clima provocadas pela interferência antrópica, conforme pode-se observar na leitura dos textos. Nos três documentos, assim como o capítulo de Revisão Bibliográfica nesta dissertação já abordou, a seca de 2013 a 2015 é vista como um ponto isolado no que tange à observação dos fenômenos climáticos no estado de São Paulo ao longo dos anos.

No relatório de 2013, tem-se também o capítulo sobre segurança hídrica em decorrência das adversidades climáticas, a partir de então é observada uma preocupação maior da companhia com a diminuição das vazões dos mananciais - é citada, por exemplo, a queda de armazenamento do Sistema Cantareira. Para a região litorânea, o relatório em particular faz uma observação de elevação da temperatura. "No final de 2013 as cidades da Baixada receberam mais de 3,6 milhões de visitantes e, somente entre o início de janeiro e meados de março de 2013, a cidade do Guarujá atingiu por 27 vezes a maior temperatura do país" (p. 29). No relatório de 2014, tal capítulo também é incluído, com o relato da Sabesp sobre a queda brusca de armazenamento do Sistema Cantareira; no documento, a companhia já relata sobre os impactos da estiagem prolongada. "Importantes institutos meteorológicos brasileiros não conseguiram que seus radares detectassem com antecedência a gravidade da situação, que afetou também regiões do interior paulista e estados próximos como o Rio de Janeiro, Minas Gerais e Espírito Santo” (p. 17). No relatório de 2015, este capítulo não aparece mais, para dar lugar ao capítulo "Construindo o Futuro do Abastecimento - Segurança Hídrica", visando um possível término da estiagem prolongada e dando um tom de variedade de abastecimento de água. "Possibilidade de atendimento por diferentes sistemas produtores 
demonstra flexibilidade de infraestrutura de abastecimento, que foi ampliada com as obras executadas no biênio 2014-2015" (p. 31).

Medidas de mitigação ao abastecimento de água são as que mais aparecem neste segundo período analisado, como construção de novas adutoras, novos pontos de captação de água, interligação de reservatórios superficiais, perfuração de novos poços subterrâneos. Ações de eficiência são relacionadas à mitigação das secas pela companhia nos relatórios, como as perdas de água, em que a companhia traça metas de redução de curto e longo prazo, e avalia os anos anteriores em relação a este indicador.

Ainda neste segundo período analisado, há capítulos que discorrem sobre o consumo consciente de água como plano almejado pela companhia e, consequentemente, adotado pela população, resultando na diminuição do consumo de água na Região Metropolitana de São Paulo. Este fator é tratado nos documentos como êxito perante a consciência criada pela população paulista da RMSP acerca das incertezas dos próximos anos à seca. As obras de tratamento de esgoto, que têm impactos diretos na qualidade dos mananciais superficiais, e outros afluentes, são trabalhados de maneira secundária nos relatórios, até mesmo pelo fato de a empresa ter assumido uma posição de estagnação de investimentos neste setor em específico, diante das necessidades emergentes de mitigar os efeitos da crise hídrica com construção e realocação de recursos para novos sistemas hídricos. Os capítulos sobre mudanças climáticas se mantiveram no discurso alinhado à perspectiva de como a companhia colabora com a redução da emissão de gases, como o metano, presente nas estações de tratamento de esgoto.

No terceiro período analisado, é possível observar os efeitos da crise de 2013 a 2015. Neste período, são exaltados os êxitos da Sabesp na mitigação da crise hídrica com os investimentos na segurança hídrica do estado. Não é descartada a ocorrência de novas secas intensas, contudo, a análise dos documentos evidencia que não há menção a projeções climáticas para o futuro acerca de possíveis eventos extremos nos municípios operados pela Sabesp. Novamente, os relatórios fazem uma leitura geral do quadro de eficiência da empresa e das contribuições frente às mudanças climáticas, repetindo os últimos relatórios nos quais são citadas as ações tomadas para a redução da emissão de gases e outras ações de mitigação para a manutenção dos ecossistemas. No relatório de 2016, é proposto um capítulo intitulado de "Superação da Crise Hídrica, Legados e o Aprimoramento da Gestão", redigido pelo presidente da Sabesp da época, com foco no sucesso obtido pela companhia em enfrentar o período da seca com investimentos em obras de produção de água e abastecimento. No 
relatório de 2017, a companhia segue a mesma linha de 2015 com o capítulo de "Segurança Hídrica para o Presente e o Futuro", com foco no consumo per capita na RMSP, no qual a Sabesp afirma que a população compreendeu o papel dela durante o período de estiagem e colaborou reduzindo o próprio consumo. “Em 2017, a média diária produzida de água tratada na RMSP foi 12\% menor que 2013, ano anterior à deflagração da crise. Há quatro anos, picos médios diários chegavam a 71,4 $\mathrm{m}^{3} / \mathrm{s}$, o que demonstra a consolidação de hábitos racionais de consumo" (p. 27) No Relatório de Sustentabilidade de 2018, é possível observar que a Sabesp reconhece ter enfrentado uma nova estiagem naquele ano, o que trouxe impactos aos principais mananciais da RMSP, porém de maneira menos drástica, quando comparado ao período de 2013 a 2015. A empresa demonstra uma preocupação maior com novos métodos de ampliação de sistemas de produção de água nestes relatórios do terceiro período, como o reúso e, novamente, a redução das perdas de água.

Para elucidar os achados, o Quadro 8 traz uma síntese dos principais elementos das entrevistas coletadas.

\section{Quadro 8-Achados nos Relatórios de Sustentabilidade da Sabesp}

\begin{tabular}{|c|c|}
\hline Principais tópicos & Conteúdos identificados \\
\hline $\begin{array}{l}\text { Aborda as Mudanças Climáticas ou eventos } \\
\text { extremos climáticos? }\end{array}$ & $\begin{array}{l}\text { Sim, principalmente nos Relatórios de } 2013 \text { a } \\
2015 \text {, no auge da crise hídrica do estado de } \\
\text { São Paulo. Os termos mais encontrados nos } \\
\text { relatórios são "seca", "estiagem", "crise } \\
\text { hídrica". }\end{array}$ \\
\hline $\begin{array}{l}\text { Vislumbra metas estratégicas de negócios } \\
\text { que consideram as Mudanças Climáticas? }\end{array}$ & $\begin{array}{l}\text { Todas as ações conectadas às secas são obras } \\
\text { de infraestrutura cinza, com interligação de } \\
\text { reservatórios e construção de novos modelos } \\
\text { de reservação. A mitigação por meio de } \\
\text { redução de } \mathrm{CO}_{2} \text { e } \mathrm{CH}_{4} \text { nas estações de } \\
\text { tratamento de água e esgoto é relatada em } \\
\text { todos os relatórios, especialmente com uma } \\
\text { apresentação feita pela Sabesp na COP-15 }\end{array}$ \\
\hline
\end{tabular}

Fonte: Elaboração do autor 


\section{2 - ENTREVISTAS - PERCEPÇÕES \\ 4.2.1 - Mudanças Climáticas}

Por meio das transcrições e análises das entrevistas semiestruturadas realizadas, o primeiro eixo analítico tratado refere-se à percepção dos entrevistados em relação às mudanças climáticas. Cabe destacar que nenhum entrevistado é especialista em climatologia, ou trabalha/trabalhou em departamentos específicos relacionados nas instituições escolhidas.

Os entrevistados da Cagece e Sabesp (companhias), além do Instituto Sisar (organização), ocuparam, ou ainda ocupam, ofícios com responsabilidades no planejamento das operações de água e esgotamento sanitário em cada estado, e as tomadas de decisões foram ou são as mais importantes tarefas executadas por eles. As questões, portanto, apresentadas neste eixo são centradas nos períodos de estiagens prolongadas ocorridas nos dois estados durante a década de 2010, em que as companhias de saneamento básico e a organização tiveram papéis importantes nas discussões com a sociedade civil no planejamento da operação dos serviços de água e esgotamento sanitário. A análise das transcrições permite compreender que os entrevistados percebem que há uma mudança do clima em vigência, e que isso pode ter ligação com os períodos de seca prolongados vividos por ambos os locais nos anos mais recentes. Contudo, identificar estas mudanças climáticas como ações antrópicas ainda não é claro para alguns dos entrevistados. Esses, em sua maioria, não conseguem ter um entendimento claro de que os eventos extremos advêm das mudanças climáticas provocadas pelas atividades humanas. Dois ex-presidentes executivos das companhias entrevistados relataram, por exemplo, que as mudanças climáticas já eram pauta da Cagece e Sabesp por anos com os acionistas, em especial para a companhia paulista que tem ações nas bolsas de valores de São Paulo e Nova Iorque. Observa-se, assim, que as percepções sobre as mudanças climáticas existem, mesmo que não sejam construídas tecnicamente dentro das próprias companhias ou organizações, como relataram os entrevistados.

O enfoque na questão hídrica sobre as mudanças climáticas é o mais constatado nas entrevistas realizadas com representantes da Cagece, Sabesp e Instituto Sisar. Os entrevistados atribuem o reconhecimento às mudanças do clima a partir da ótica da vazão dos reservatórios superficiais que abastecem os municípios. No caso do Ceará, tanto pela Cagece, quanto pelo Instituto Sisar, os entrevistados citam frequentemente o termo "convivência com a seca", reconhecendo a seca como uma condição inerente do estado. Reconhecem, ainda, que o futuro em relação a esta condição climática pode ser mais desafiador. Ainda que ambas as companhias se valham de séries históricas de institutos de pesquisas de meteorologia para 
discutir as secas prolongadas nos estados do Ceará e São Paulo, a escala temporal destes dados ainda é apontada como insuficiente para concluir que os acontecimentos estão atrelados às mudanças climáticas. Isso também se repete na discussão sobre incertezas futuras. Os entrevistados das companhias e da organização não emitem opiniões assertivas sobre cenários futuros do clima e impactos para os serviços de saneamento básico.

Ao entrevistar representantes das agências reguladoras do Ceará e São Paulo - Arce e Sabesp -, é possível aferir percepções similares aos dos entrevistados pelas companhias de água e esgoto. Para o entrevistado da Arce, a seca prolongada de 2012 a 2018 é compreendida como alarmante por nunca ter acontecido antes em termos de longevidade; no entanto, ele não faz atribuição direta do mesmo evento extremo às mudanças climáticas. Para ele, a seca não deve ser vista como algo isolado, mas sim corriqueiro para o estado; contudo, a intensificação dela precisa ser reconhecida como efeito das mudanças climáticas. Para o representante da Arsesp, a percepção de como as mudanças climáticas estão se tornando pauta mais corriqueira para a sociedade e empresas é mais consolidada, particularmente considerando a última ocorrência de seca prolongada no estado de São Paulo, de 2013 a 2015. Para ele, há uma preocupação quanto à incerteza do futuro, principalmente ao analisar "a curta série histórica" - como identifica o recorte temporal - já que não há segurança de como São Paulo vai se comportar no futuro em relação ao clima, citando até mesmo uma possível diminuição da temperatura e não aquecimento na região.

Nas entrevistas, é possível compreender que as percepções são moldadas a partir dos eventos extremos de seca registrados recentemente; a intensificação de precipitações é citada muito pouco por apenas alguns dos entrevistados. Já para os representantes da sociedade civil do Ceará e São Paulo - EloAmigo/ASA e SOS Mata Atlântica -, a análise das entrevistas permite aferir que ambos reconhecem as mudanças climáticas, situando os eventos extremos de seca prolongada nos dois estados como mais um acontecimento registrado nos locais referente ao clima. Para o representante do EloAmigo/ASA, o estado precisa conviver com a seca, pois é uma condição de séculos. Entretanto, destaca como a industrialização no Ceará, assim como o uso irregular desenfreado do solo, são condicionantes para uma alteração do clima mais intensa. O processo de desertificação no estado cearense é apontado constantemente pelo representante da sociedade civil como uma ação antrópica na região, que causou a aceleração das secas prolongadas, e que faz o estado cearense repensar em como conviver com a seca intensa no futuro. Para a representante da SOS Mata Atlântica, as 
mudanças climáticas são visíveis frente à seca de 2013 a 2015 no estado, principalmente com o desmatamento acelerado em regiões de São Paulo e a urbanização acelerada.

A maneira como a sociedade responde às mudanças climáticas é apontada pela representante desta ONG como a mais preocupante. Em seu entendimento, houve uma possível histeria coletiva no período de seca em São Paulo pela desinformação do que estava ocorrendo, tanto do ponto de vista climático, como operacional em oferta hídrica. Em São Paulo, a entrevistada acredita que ainda há uma luz amarela sobre a seca no estado, principalmente na RMSP, e que a qualquer momento pode acontecer um novo período tão intenso como identificado há poucos anos. Para elucidar os achados, o Quadro 9 traz uma síntese dos principais elementos das entrevistas coletadas. 
Quadro 9 - Percepções dos entrevistados sobre as mudanças climáticas

\begin{tabular}{|c|c|c|c|c|c|c|c|}
\hline \multirow{3}{*}{$\begin{array}{c}\text { Assuntos } \\
\text { Abordados }\end{array}$} & \multicolumn{7}{|c|}{ Percepções dos entrevistados } \\
\hline & \multicolumn{3}{|c|}{ Operadores de água e esgotamento sanitário } & \multicolumn{2}{|c|}{ Agências reguladoras } & \multicolumn{2}{|c|}{ Organizações da Sociedade Civil } \\
\hline & Cagece & Sabesp & Instituto Sisar & Arce & Arsesp & $\begin{array}{c}\text { Elo/Amigo - } \\
\text { ASA }\end{array}$ & $\begin{array}{l}\text { SOS Mata } \\
\text { Atlântica }\end{array}$ \\
\hline $\begin{array}{l}\text { Mudanças } \\
\text { Climáticas }\end{array}$ & $\begin{array}{l}\text { Reconhecem } \\
\text { que há } \\
\text { mudanças } \\
\text { climáticas por } \\
\text { meio dos } \\
\text { eventos de } \\
\text { escassez } \\
\text { hídrico } \\
\text { vivenciados } \\
\text { nos últimos } \\
\text { anos, mas se } \\
\text { mostram } \\
\text { incertos em } \\
\text { relação às } \\
\text { ações } \\
\text { antrópicas }\end{array}$ & $\begin{array}{l}\text { Reconhecem } \\
\text { que há } \\
\text { mudanças } \\
\text { climáticas por } \\
\text { meio dos } \\
\text { eventos de } \\
\text { escassez } \\
\text { hídrico } \\
\text { vivenciados } \\
\text { nos últimos } \\
\text { anos, mas se } \\
\text { mostram } \\
\text { incertos em } \\
\text { relação às } \\
\text { ações } \\
\text { antrópicas }\end{array}$ & $\begin{array}{l}\text { Reconhece que há } \\
\text { mudanças } \\
\text { climáticas, por } \\
\text { meio dos eventos } \\
\text { de escassez hídrico } \\
\text { vivenciados nos } \\
\text { últimos anos, mas } \\
\text { se mostra incertos } \\
\text { em relação às ações } \\
\text { antrópicas }\end{array}$ & $\begin{array}{l}\text { Reconhece que há } \\
\text { mudanças } \\
\text { climáticas, por } \\
\text { meio dos eventos } \\
\text { de escassez } \\
\text { hídrico } \\
\text { vivenciados nos } \\
\text { últimos anos }\end{array}$ & $\begin{array}{l}\text { Reconhece que há } \\
\text { mudanças } \\
\text { climáticas, mas } \\
\text { classifica como } \\
\text { "mudanças } \\
\text { hidrológicas" }\end{array}$ & $\begin{array}{l}\text { Reconhece que } \\
\text { há mudanças } \\
\text { climáticas, tendo } \\
\text { como elemento } \\
\text { precursor a ação } \\
\text { antrópica, e } \\
\text { coloca o } \\
\text { processo de } \\
\text { desertificação do } \\
\text { estado como } \\
\text { parte do } \\
\text { resultado das } \\
\text { mudanças } \\
\text { climáticas }\end{array}$ & $\begin{array}{l}\text { Reconhece que há } \\
\text { mudanças } \\
\text { climáticas, tendo } \\
\text { como indicativos } \\
\text { os desmatamentos } \\
\text { e urbanização } \\
\text { desenfreada }\end{array}$ \\
\hline
\end{tabular}




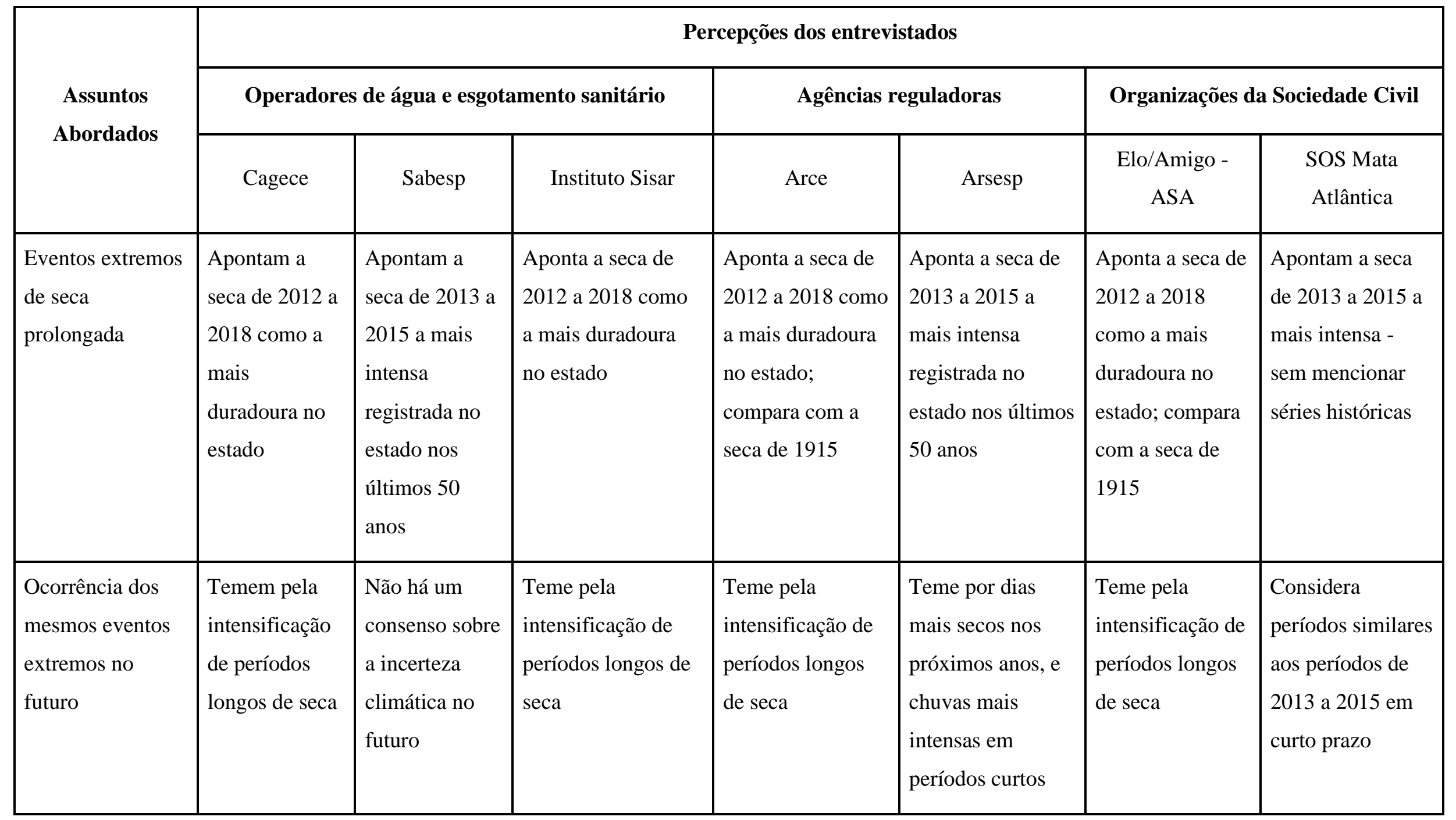

Fonte: Elaboração do autor 


\subsection{2 - Riscos dos impactos das mudanças climáticas}

Nesta categoria analítica, as entrevistas são analisadas a partir das narrativas sobre a perspectiva de escassez hídrica nos estados do Ceará e São Paulo enquanto impactos das mudanças climáticas nos territórios, ainda que, como mostrado no subcapítulo anterior, há divergências quanto ao fato de o evento extremo de seca ter ligação com as mudanças climáticas. Para os entrevistados da Cagece e Instituto Sisar, observa-se um discurso focado no impacto ao acesso à água para as áreas mais vulneráveis do estado cearense. Ao mesmo tempo, os entrevistados destas instituições demonstram preocupação com a urbanização da Região Metropolitana de Fortaleza, correlacionando a possibilidade do clima se alterar ainda mais devido ao uso irregular do solo e à poluição dos corpos hídricos. A seca de 2012 a 2018 é trazida constantemente ao debate pelos entrevistados quando apontam as cidades do interior como as mais impactadas pelo evento extremo pela vulnerabilidade socioeconômica.

Em São Paulo, os entrevistados da Sabesp percebem também o risco de inundações como impactos das mudanças climáticas; contudo, a seca ainda é vista como o evento mais prejudicial ao considerar o provável impacto das mudanças climáticas. Em algumas narrativas dos entrevistados da Sabesp, é possível observar preocupação com o consumo de alimentos e energia, os quais são colocados em risco frente aos impactos das mudanças climáticas.

Os entrevistados das agências reguladoras Arce e Arsesp apresentam relatos similares ao discurso hídrico reproduzido pelas companhias e o instituto. A escassez de água é vista novamente como o maior risco em relação ao impacto das mudanças climáticas nos dois estados. No Ceará, o entrevistado da Arce considera a baixa disponibilidade hídrica como impacto direto das constantes secas, e reconhece não associar outro impacto mais intenso do que a escassez de água para abastecimento humano. $\mathrm{O}$ aquecimento da Terra em até $1,5^{\circ} \mathrm{C}$ é apontado pelo entrevistado da Arsesp como indicador de impacto à vazão dos mananciais, atribuindo esse impacto às mudanças climáticas. Ele considera os aspectos econômicos como elementos relevantes a serem considerados em relação aos impactos das mudanças climáticas.

Os representantes da sociedade civil possuem percepções variadas em relação aos impactos das mudanças climáticas, indo além da disponibilidade hídrica. Para o 
entrevistado do EloAmigo/ASA, as políticas praticadas pelo Governo Federal e Estadual em épocas passadas reduziram os impactos para a população que convive no semiárido, contudo, a incerteza climática coloca em risco também a sobrevivência deste povo. Para ele, não se deve mais abordar termos referentes ao combate da seca, mas sim de mitigação da mesma, em todos os aspectos socioeconômicos, inclusive o acesso à água. Para a entrevistada da SOS Mata Atlântica, os impactos estão mais diretamente associados ao acesso à água e às infraestruturas urbanas, que podem trazer transtornos para a saúde pública, sobretudo do ponto de vista da própria população buscar alternativas para reduzir os efeitos negativos das mudanças climáticas. Para elucidar os achados, o Quadro 10 traz uma síntese das narrativas coletadas. 
Quadro 10 - Percepções dos entrevistados sobre os impactos das mudanças climáticas em aspectos gerais

\begin{tabular}{|c|c|c|c|c|c|c|c|}
\hline \multirow{3}{*}{$\begin{array}{c}\text { Assuntos } \\
\text { Abordados }\end{array}$} & \multicolumn{7}{|c|}{ Percepções dos entrevistados } \\
\hline & \multicolumn{3}{|c|}{ Operadores de água e esgotamento sanitário } & \multicolumn{2}{|c|}{ Agências reguladoras } & \multicolumn{2}{|c|}{ Organizações da Sociedade Civil } \\
\hline & Cagece & Sabesp & Instituto Sisar & Arce & Arsesp & Elo/Amigo - ASA & $\begin{array}{l}\text { SOS Mata } \\
\text { Atlântica }\end{array}$ \\
\hline $\begin{array}{l}\text { Quais impactos } \\
\text { causados pelas } \\
\text { mudanças } \\
\text { climáticas }\end{array}$ & $\begin{array}{l}\text { Água e } \\
\text { habitação }\end{array}$ & $\begin{array}{l}\text { Água, energia, } \\
\text { consumo de } \\
\text { alimentos }\end{array}$ & $\begin{array}{l}\text { Água e } \\
\text { urbanização }\end{array}$ & Água & Água e economia & $\begin{array}{l}\text { Água, segurança } \\
\text { alimentar, moradias }\end{array}$ & $\begin{array}{l}\text { Água, } \\
\text { infraestrutura } \\
\text { urbana, saúde } \\
\text { pública }\end{array}$ \\
\hline $\begin{array}{l}\text { Como se dão os } \\
\text { impactos na } \\
\text { sociedade }\end{array}$ & $\begin{array}{l}\text { Escassez de } \\
\text { água e } \\
\text { habitação }\end{array}$ & $\begin{array}{l}\text { Escassez de } \\
\text { água. Não } \\
\text { foram citados } \\
\text { como os } \\
\text { impactos se } \\
\text { dão na energia } \\
\text { e consumo de } \\
\text { alimentos }\end{array}$ & $\begin{array}{l}\text { Escassez de água; } \\
\text { poluição dos } \\
\text { corpos hídricos } \\
\text { devido à } \\
\text { urbanização }\end{array}$ & $\begin{array}{l}\text { Escassez de } \\
\text { água }\end{array}$ & $\begin{array}{l}\text { Escassez de água; } \\
\text { aumento das } \\
\text { tarifas para } \\
\text { consumo de água }\end{array}$ & $\begin{array}{l}\text { Escassez de água; } \\
\text { redução de alimentos } \\
\text { para consumo; } \\
\text { emigração para outras } \\
\text { áreas }\end{array}$ & $\begin{array}{l}\text { Escassez de } \\
\text { água; impacto } \\
\text { no fornecimento } \\
\text { de energia; mais } \\
\text { doenças } \\
\text { relacionadas } \\
\text { alternativas } \\
\text { adotadas pelas } \\
\text { comunidades }\end{array}$ \\
\hline
\end{tabular}

Fonte: Elaboração do autor 


\subsection{3 - Riscos dos impactos das mudanças climáticas ao setor de saneamento básico}

Ao considerar as diferentes percepções sobre mudanças climáticas e os impactos gerais, neste terceiro eixo analítico o foco está nas perspectivas distintas dos entrevistados em relação aos riscos das mudanças climáticas para o setor do saneamento. Em comum, os atores, em suas entrevistas, consideraram os períodos de seca prolongados e a alta precipitação como os maiores desafios para o setor de água e esgotamento sanitário.

Os representantes das companhias Cagece e Sabesp e do Instituto Sisar, em suas entrevistas, explanaram novamente os casos das secas de 2012 a 2018 (Ceará), e 2013 a 2015 (São Paulo), ressaltando a redução do volume de água nos mananciais de captação de água bruta e os desafios de abastecimento de água para ambos estados naqueles períodos. A análise das entrevistas permite compreender que no Ceará, onde a cultura da seca está mais presente, os impactos que as estiagens provocaram ao longo dos anos em todos os aspectos ofereceram oportunidades para pensar em maneiras diferentes de prover água para a população. Os entrevistados ressaltaram que a identificação dos impactos no setor de abastecimento de água levou à criação e integração entre órgãos públicos do governo para garantir segurança hídrica. Eles ressaltaram a participação da Cagece nos grupos de discussões sobre seca do Governo Estadual e Federal, a fim de trazer soluções de redução dos impactos. As entrevistas revelaram também as percepções dos entrevistados acerca da alta precipitação nas regiões litorâneas, que causaram danos à infraestrutura de esgotamento sanitário, com sobrecarga das estações de tratamento de esgoto em dias de chuvas intensas em um único período, e tubulações de esgoto recebendo água de chuva por ligações irregulares do sistema de drenagem. Para o Instituto Sisar, o maior impacto das mudanças climáticas no setor de saneamento básico está, sobretudo, no gerenciamento dos sistemas de água que são operados pelas comunidades. Para ele, as mudanças climáticas podem ocasionar paralisação dos sistemas comunitários por falta de opções de captação de água.

Para os entrevistados da Sabesp, os impactos também são da ordem de captação de água e distribuição para a população, justificando suas narrativas com os acontecimentos relacionados à estiagem. A análise das entrevistas possibilita identificar a percepção também acerca do impacto financeiro para a Sabesp devido às obras emergenciais, descritas pelos entrevistados como um momento de planejar no curto prazo com construção de obras vultosas para garantir mais acesso à água para a RMSP. Outro impacto identificado pelos entrevistados está no próprio relacionamento com os consumidores, reflexos também das 
campanhas para redução do consumo de água. Além disso, os transbordos das estações de tratamento de esgoto também são vistos como pontos de atenção pelos representantes da Sabesp, particularmente durante alta precipitação; ainda que reconheçam que há um preparo melhor para recebimento de volumes altos de chuva em períodos curtos. Por fim, os entrevistados da Sabesp ressaltam o impacto das ligações irregulares de esgoto nos sistemas de drenagem, bem como a Cagece, como infraestrutura passiva de ser impactada com a alta precipitação.

Os entrevistados das agências reguladoras focaram neste eixo analítico somente avaliando o impacto que as companhias de água e esgoto podem ter pela escassez de água, obrigando-as a executarem obras emergenciais sem previsão de investimentos. Os discursos dos entrevistados se assemelham à medida que eles apontam um maior impacto associado às mudanças climáticas ao saneamento na qualidade, quantidade e preço da água no futuro. Para a Arsesp em específico, todo o acontecimento trazido pela seca de 2013 a 2015 permitiu que a agência reguladora repensasse com mais eficiência sobre como incorporar os impactos das mudanças climáticas até mesmo nas revisões tarifárias. A valorização monetária da água foi um tema bastante abordado, que será trabalhado no tópico seguinte.

Para as entidades da sociedade civil, o impacto das mudanças climáticas no setor de saneamento básico está, sobretudo, na gestão dos serviços, mais do que na quantidade e qualidade da água. O entrevistado da EloAmigo/ASA reconhece que a escassez de recursos hídricos é o maior impacto para o setor de saneamento, e a ausência de planejamento do setor pode ter algum impacto para os consumidores se não reconhecerem as deficiências, que serão acentuadas com as mudanças climáticas. A entrevistada da SOS Mata Atlântica sinaliza que o maior impacto está no entendimento de como as companhias de saneamento se colocam perante os recursos hídricos em momentos de eventos extremos. Para ela, é nítido que as companhias têm os impactos potencializados com as mudanças climáticas por não se articularem com outros setores. A escassez hídrica é vista como um ponto nevrálgico para a entrevistada, que também teme pela ineficiência das companhias perante os períodos de intensificação da seca. Para elucidar os achados, o Quadro 11 traz uma síntese das entrevistas transcritas. 
Quadro 11 - Percepções dos entrevistados sobre os impactos das mudanças climáticas ao setor de abastecimento de água e esgotamento sanitário

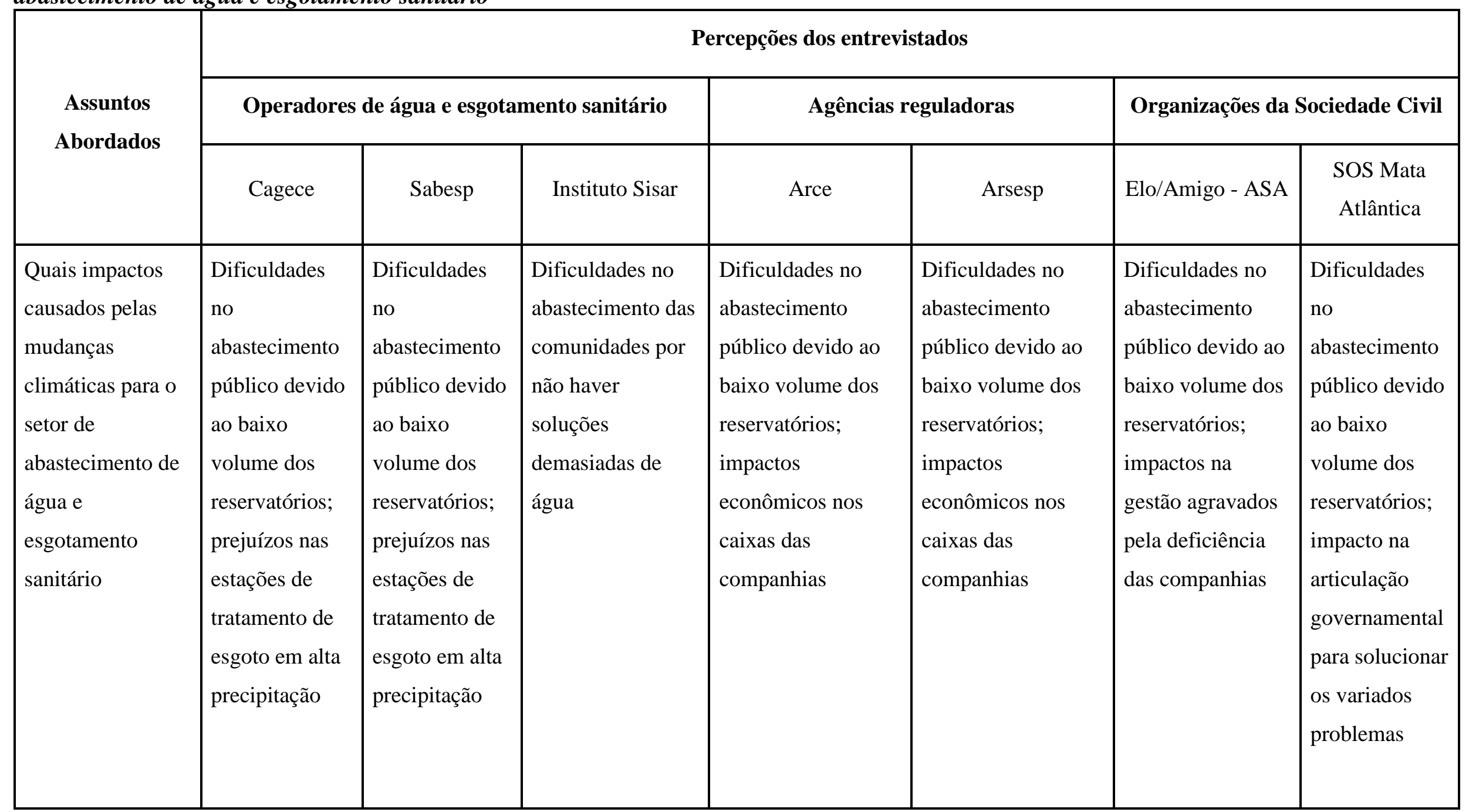




\begin{tabular}{|c|c|c|c|c|c|c|c|}
\hline \multirow{3}{*}{$\begin{array}{c}\text { Assuntos } \\
\text { Abordados }\end{array}$} & \multicolumn{7}{|c|}{ Percepções dos entrevistados } \\
\hline & \multicolumn{3}{|c|}{ Operadores de água e esgotamento sanitário } & \multicolumn{2}{|c|}{ Agências reguladoras } & \multicolumn{2}{|c|}{ Organizações da Sociedade Civil } \\
\hline & Cagece & Sabesp & Instituto Sisar & Arce & Arsesp & Elo/Amigo - ASA & $\begin{array}{l}\text { SOS Mata } \\
\text { Atlântica }\end{array}$ \\
\hline $\begin{array}{l}\text { Quais soluções } \\
\text { podem ser } \\
\text { adotadas perante } \\
\text { os impactos } \\
\text { causados ao setor }\end{array}$ & $\begin{array}{l}\text { Fortalecimento } \\
\text { da } \\
\text { infraestrutura } \\
\text { cinza por meio } \\
\text { de construção } \\
\text { de } \\
\text { reservatórios, } \\
\text { interligação de } \\
\text { bacias; projetos } \\
\text { de reúso; } \\
\text { projetos de } \\
\text { dessalinização }\end{array}$ & $\begin{array}{l}\text { Fortalecimento } \\
\text { da } \\
\text { infraestrutura } \\
\text { cinza por meio } \\
\text { de construção } \\
\text { de } \\
\text { reservatórios, } \\
\text { interligação de } \\
\text { bacias; } \\
\text { projetos de } \\
\text { reúso; projetos } \\
\text { de } \\
\text { dessalinização }\end{array}$ & $\begin{array}{l}\text { Perfurar poços; } \\
\text { fortalecer } \\
\text { parcerias } \\
\text { institucionais para } \\
\text { garantir mais } \\
\text { investimentos; } \\
\text { garantir novos } \\
\text { modelos de } \\
\text { abastecimento de } \\
\text { água }\end{array}$ & $\begin{array}{l}\text { Busca por novas } \\
\text { tecnologias para } \\
\text { abastecimento de } \\
\text { água; investir em } \\
\text { interligação de } \\
\text { açudes. }\end{array}$ & $\begin{array}{l}\text { Busca por projetos } \\
\text { de reúso e } \\
\text { dessalinização; }\end{array}$ & $\begin{array}{l}\text { Estudar formas de } \\
\text { reúso para } \\
\text { também a } \\
\text { agricultura; } \\
\text { buscar novas } \\
\text { opções } \\
\text { tecnológicas; } \\
\text { fortalecer as } \\
\text { instituições para } \\
\text { trabalharem em } \\
\text { conjunto }\end{array}$ & $\begin{array}{l}\text { Engajar as } \\
\text { companhias } \\
\text { para } \\
\text { programas de } \\
\text { solução da } \\
\text { natureza; } \\
\text { apoiar o } \\
\text { reflorestament } \\
\text { o; ter mais } \\
\text { ambições nos } \\
\text { projetos de } \\
\text { despoluição de } \\
\text { rios para } \\
\text { usarem como } \\
\text { fonte de água; }\end{array}$ \\
\hline
\end{tabular}




\begin{tabular}{|c|c|c|c|c|c|c|c|}
\hline \multirow{3}{*}{$\begin{array}{c}\text { Assuntos } \\
\text { Abordados }\end{array}$} & \multicolumn{7}{|c|}{ Percepções dos entrevistados } \\
\hline & \multicolumn{3}{|c|}{ Operadores de água e esgotamento sanitário } & \multicolumn{2}{|c|}{ Agências reguladoras } & \multicolumn{2}{|c|}{ Organizações da Sociedade Civil } \\
\hline & Cagece & Sabesp & Instituto Sisar & Arce & Arsesp & Elo/Amigo - ASA & $\begin{array}{l}\text { SOS Mata } \\
\text { Atlântica }\end{array}$ \\
\hline $\begin{array}{l}\text { O setor de água e } \\
\text { esgoto está } \\
\text { preparado para os } \\
\text { impactos das } \\
\text { mudanças } \\
\text { climáticas? }\end{array}$ & $\begin{array}{l}\text { Consideram } \\
\text { que a Cagece } \\
\text { está se } \\
\text { preparando } \\
\text { para mais } \\
\text { eventos como a } \\
\text { seca de } 2012 \text { a } \\
2018 . \\
\text { Entendem que } \\
\text { o setor de } \\
\text { saneamento } \\
\text { básico no } \\
\text { Brasil não se } \\
\text { preocupa com } \\
\text { o tema. }\end{array}$ & $\begin{array}{l}\text { Consideram } \\
\text { que a Sabesp } \\
\text { está preparada } \\
\text { para eventos } \\
\text { similares ao da } \\
\text { seca de } 2013 \text { a } \\
2015 . \\
\text { Entendem que } \\
\text { o setor de } \\
\text { saneamento } \\
\text { básico no } \\
\text { Brasil não se } \\
\text { preocupa com } \\
\text { o tema. }\end{array}$ & $\begin{array}{l}\text { Considera o } \\
\text { estado do Ceará } \\
\text { mais preparado do } \\
\text { que antes. } \\
\text { Não opinou sobre } \\
\text { o setor como um } \\
\text { todo. }\end{array}$ & $\begin{array}{l}\text { Considera o estado } \\
\text { do Ceará mais } \\
\text { preparado do que } \\
\text { antes. } \\
\text { Entende que o setor } \\
\text { de saneamento } \\
\text { básico no Brasil } \\
\text { não se preocupa } \\
\text { com o tema. }\end{array}$ & $\begin{array}{l}\text { Atribui uma } \\
\text { atenção maior por } \\
\text { parte dos } \\
\text { municípios e } \\
\text { companhias em } \\
\text { relação ao assunto. } \\
\text { Não opinou sobre o } \\
\text { setor como um } \\
\text { todo. }\end{array}$ & $\begin{array}{l}\text { Não opinou sobre } \\
\text { o assunto }\end{array}$ & $\begin{array}{l}\text { Entende que o } \\
\text { setor de } \\
\text { saneamento } \\
\text { básico no } \\
\text { Brasil não se } \\
\text { preocupa com } \\
\text { o tema. }\end{array}$ \\
\hline
\end{tabular}

Fonte: Elaboração do autor 


\section{3 - O PREÇO DA ÁGUA}

A análise de conteúdo das entrevistas mostra que o abastecimento de água ainda é o maior ponto de debate do setor de saneamento básico ao ser contraposto às mudanças climáticas. Por este ponto, as entrevistas permitiram explorar os conteúdos acerca do valor da água enquanto recurso natural disponibilizado para consumo humano e monetizado para que os serviços de distribuição sejam remunerados. No Brasil, a água é reconhecida como valor econômico por meio da Constituição Federal e a Política Nacional de Recursos Hídricos (DE LIMA et al., 2018).

Nos momentos de estiagens prolongadas nos dois estados foi observada a adoção de medidas tarifárias diferentes por parte da Cagece e Arce; e Sabesp e Arsesp. Os entrevistados atribuem uma mudança de comportamento das companhias por vivenciarem as secas, e atribuem a queda dos consumos nos dois estados ao entendimento da população sobre valores da água. No Ceará, para conter o consumo, os documentos analisados no início deste capítulo apontaram a tarifa de contingência, e os entrevistados recorrem a este tema para justificarem que a redução de consumo de água imposta para a população cearense atendida pela Cagece era necessária para que a água fosse reconhecida como um item de relevância em prol da segurança hídrica.

O mesmo ocorreu em São Paulo. Os entrevistados enxergaram benefícios para o bônus tarifário implantado pela Sabesp e Arsesp. Diferentemente do que houve no Ceará, o bônus premiava aqueles que consumissem menos com redução nas contas de água. Em uma das entrevistas é sugerida a criação de um sistema tarifário de segurança hídrica, baseado na energia elétrica, com bandeiras de consumo. Para o agente regulador do estado de São Paulo, os investimentos feitos pela Sabesp durante o período da estiagem foram acertadamente acatados na última revisão tarifária de 2017, que repassou para o consumidor os recursos despendidos pela companhia.

Em ambo os estados, alguns dos entrevistados foram além da avaliação tarifária da água, abordando um conceito semelhante sobre o pagamento da água por parte de quem tem mais poder aquisitivo, na perspectiva de que os grupos mais vulneráveis economicamente fossem beneficiados com tarifas menores. Mesmo que exista a tarifa social nos dois estados, em que famílias mais vulneráveis pagam pelo consumo de $10 \mathrm{~m}^{3}$ de água de maneira fixa, o debate em torno da flexibilização tarifária seguindo conceitos econômicos e sociais apareceu frequentemente até mesmo pelos agentes reguladores. 
A pesquisa não buscou compreender como foram feitas as revisões tarifárias de ambos os estados após os períodos de estiagens, por entender que as metodologias empregadas consideram outras variáveis não discutidas nesta dissertação. Nas entrevistas com os representantes da Cagece e Sabesp, verifica-se que as tarifas adotadas para amortizar os investimentos realizados com as obras emergenciais são supostamente bem avaliadas pela população. Ao mesmo tempo, os entrevistados reconhecem como positiva a percepção da população em relação ao valor da água, atribuindo a queda nos consumos ao entendimento da sociedade sobre a pouca disponibilidade hídrica. Para elucidar os achados, o Quadro 12 traz uma síntese das entrevistas transcritas. 
Quadro 12 - Percepções dos entrevistados sobre o valor da água sob a ótica dos impactos causados pelas mudanças climáticas

\begin{tabular}{|c|c|c|c|c|c|c|c|}
\hline \multirow{3}{*}{$\begin{array}{c}\text { Assuntos } \\
\text { Abordados }\end{array}$} & \multicolumn{7}{|c|}{ Percepções dos entrevistados } \\
\hline & \multicolumn{3}{|c|}{ Operadores de água e esgotamento sanitário } & \multicolumn{2}{|c|}{ Agências reguladoras } & \multicolumn{2}{|c|}{ Organizações da Sociedade Civil } \\
\hline & Cagece & Sabesp & Instituto Sisar & Arce & Arsesp & $\begin{array}{c}\text { Elo/Amigo - } \\
\text { ASA }\end{array}$ & SOS Mata Atlântica \\
\hline $\begin{array}{l}\text { Qual a relevância } \\
\text { de discutir o valor } \\
\text { da água sobre a } \\
\text { ótica dos } \\
\text { impactos das } \\
\text { mudanças } \\
\text { climáticas? }\end{array}$ & $\begin{array}{l}\text { Para investir em } \\
\text { novos sistemas e } \\
\text { reforçar os que } \\
\text { já existem; para } \\
\text { criar a cultura da } \\
\text { valorização da } \\
\text { água enquanto } \\
\text { produto } \\
\text { oferecido em } \\
\text { quantidade e } \\
\text { qualidade }\end{array}$ & $\begin{array}{l}\text { Para investir em } \\
\text { novos sistemas e } \\
\text { reforçar os que já } \\
\text { existem; para criar } \\
\text { a cultura da } \\
\text { valorização da } \\
\text { água enquanto } \\
\text { produto oferecido } \\
\text { com qualidade }\end{array}$ & $\begin{array}{l}\text { Para dar mais } \\
\text { sustentabilidade } \\
\text { aos sistemas de } \\
\text { água em } \\
\text { comunidades } \\
\text { rurais, sem visar o } \\
\text { lucro. }\end{array}$ & $\begin{array}{l}\text { Para garantir a } \\
\text { continuidade da } \\
\text { prestação dos } \\
\text { serviços de água, } \\
\text { sem correr riscos } \\
\text { de racionamento; } \\
\text { para criar a } \\
\text { cultura da } \\
\text { valorização da } \\
\text { água enquanto } \\
\text { produto oferecido } \\
\text { em quantidade e } \\
\text { qualidade }\end{array}$ & $\begin{array}{l}\text { Para criar a } \\
\text { cultura da } \\
\text { valorização da } \\
\text { água enquanto } \\
\text { produto } \\
\text { oferecido em } \\
\text { quantidade e } \\
\text { qualidade }\end{array}$ & $\begin{array}{l}\text { É necessário } \\
\text { criar uma } \\
\text { cultura da } \\
\text { educação sobre } \\
\text { o valor da água, } \\
\text { não se vê } \\
\text { necessidade de } \\
\text { criar medidas } \\
\text { punitivas usando } \\
\text { o valor } \\
\text { monetário da } \\
\text { água em épocas } \\
\text { de escassez } \\
\text { hídrica }\end{array}$ & $\begin{array}{l}\text { Discute-se as ideias } \\
\text { de quantidade de } \\
\text { água disponível, } \\
\text { não se há menções } \\
\text { sobre o valor da } \\
\text { água enquanto } \\
\text { produto, observa-se } \\
\text { uma relevância na } \\
\text { discussão sobre o } \\
\text { valor da água } \\
\text { enquanto } \\
\text { quantidade } \\
\text { disponível para } \\
\text { consumo. }\end{array}$ \\
\hline
\end{tabular}




\begin{tabular}{|c|c|c|c|c|c|c|c|}
\hline \multirow{3}{*}{$\begin{array}{c}\text { Assuntos } \\
\text { Abordados }\end{array}$} & \multicolumn{7}{|c|}{ Percepções dos entrevistados } \\
\hline & \multicolumn{3}{|c|}{ Operadores de água e esgotamento sanitário } & \multicolumn{2}{|c|}{ Agências reguladoras } & \multicolumn{2}{|c|}{ Organizações da Sociedade Civil } \\
\hline & Cagece & Sabesp & Instituto Sisar & Arce & Arsesp & $\begin{array}{c}\text { Elo/Amigo - } \\
\text { ASA }\end{array}$ & SOS Mata Atlântica \\
\hline $\begin{array}{l}\text { O valor monetário } \\
\text { da água para } \\
\text { consumo humano } \\
\text { é adequado } \\
\text { considerando os } \\
\text { impactos } \\
\text { provocados pelas } \\
\text { mudanças } \\
\text { climáticas? }\end{array}$ & $\begin{array}{l}\text { Há controvérsias } \\
\text { nas opiniões; } \\
\text { enquanto alguns } \\
\text { acreditam que o } \\
\text { preço está } \\
\text { adequado; outros } \\
\text { acreditam que a } \\
\text { água deveria } \\
\text { valer mais, } \\
\text { especialmente } \\
\text { para quem pode } \\
\text { pagar mais }\end{array}$ & $\begin{array}{l}\text { Há controvérsias } \\
\text { nas opiniões; } \\
\text { enquanto alguns } \\
\text { acreditam que o } \\
\text { preço está } \\
\text { adequado; outros } \\
\text { acreditam que a } \\
\text { água deveria valer } \\
\text { mais, } \\
\text { especialmente } \\
\text { para quem pode } \\
\text { pagar mais }\end{array}$ & Sim & $\begin{array}{l}\text { Entende que quem } \\
\text { pode pagar mais } \\
\text { pelo valor } \\
\text { monetário da água } \\
\text { deveria dispender } \\
\text { mais de recursos } \\
\text { do que quem não } \\
\text { pode; }\end{array}$ & $\begin{array}{l}\text { Entende que } \\
\text { quem pode } \\
\text { pagar mais } \\
\text { pelo valor } \\
\text { monetário da } \\
\text { água deveria } \\
\text { dispender mais } \\
\text { de recursos do } \\
\text { que quem não } \\
\text { pode; }\end{array}$ & $\begin{array}{l}\text { Sinaliza que os } \\
\text { setores } \\
\text { produtivos } \\
\text { devem pagar } \\
\text { mais pelo uso da } \\
\text { água, pois a } \\
\text { porcentagem } \\
\text { para consumo } \\
\text { humano é baixa }\end{array}$ & $\begin{array}{l}\text { Sinaliza que as } \\
\text { companhias de } \\
\text { saneamento básico } \\
\text { precisam ser mais } \\
\text { eficientes antes de } \\
\text { incidir aumentos } \\
\text { tarifários sobre o } \\
\text { acesso à água }\end{array}$ \\
\hline
\end{tabular}

Fonte: Elaboração do autor 


\section{4 - INEFICIÊNCIA NA GESTÃO DO SANEAMENTO BÁSICO}

A análise das narrativas evidencia os enfoques sobre gestão dos impactos das mudanças climáticas e suas reverberações quanto às ineficiências do setor do saneamento, seja do ponto de vista do operador, quanto do agente regulador. Em um momento em que se discute o preço da água, como observado no tópico anterior, questionam-se os custos por parte do setor de saneamento com obras de infraestrutura cinza (interligação de reservatórios; construção de estações de tratamento de água mais volumosas; construção de novas adutoras; entre outros), além da ineficiência por parte das companhias de saneamento em relação às perdas de água, defendidas por RIBEIRO et al. (2017).

Os entrevistados percorrem os problemas que cada companhia tem em relação à redução das perdas de água, jogando luz para as dificuldades deste indicador sobre a ótica geral. Em um caso específico, um dos ex-presidentes da Sabesp entrevistados atribui a necessidade de reduzir as perdas somente em regiões de disponibilidade hídrica em menor quantidade; já em regiões que estão às margens de rios abundantes, implica-se o argumento de que não se deve despender recursos financeiros para reduzir as perdas. Para os entrevistados da Arsesp, os controles de regulação praticados pela entidade focam na redução das perdas por parte da Sabesp, dando ênfase neste item em específico para rediscutir a tarifa no futuro.

A disponibilidade de redes coletoras de esgoto e de estações de tratamento de esgoto é pouco abordada pelos entrevistados, mesmo quando questionados, e é raramente atrelada às possibilidades de utilizar este esgoto como reúso. Garantir a disponibilidade dos serviços de esgotamento sanitário é vista com dificuldade por parte dos entrevistados ao citarem áreas irregulares, com ocupação desordenada do solo, impedindo que estes serviços sejam prestados. Quando questionados sobre a despoluição de corpos hídricos para garantir mais disponibilidade hídrica nos estados, os argumentos dos representantes entrevistados da Sabesp estão mais voltados ao sucesso das políticas de despoluição dos rios para o interior, enquanto na RMSP as novas políticas de despoluição não visam garantir mais disponibilidade hídrica, como mencionado por eles. Na visão da entrevistada da SOS Mata Atlântica, o aumento da disponibilidade hídrica passa por todos os mecanismos de despoluição, não só dos rios urbanos, mas dos próprios mananciais, que hoje estão degradados, como os casos da Billings e Guarapiranga. 
No Ceará, os entrevistados pouco abordaram a questão da ineficiência de se coletar e tratar os esgotos gerados. O representante da sociedade civil EloAmigo/ASA trata sobre a ausência dos serviços de esgotamento sanitário para as áreas rurais; este fator contribui para a inutilização da água subterrânea devido à contaminação por coliformes fecais (HIRATA et al, 2019).

Do ponto de vista do agente regulador, durante as entrevistas, não foram observadas citações de indicadores voltados às mudanças climáticas como instrumentos de fiscalização sobre as companhias de saneamento. O entrevistado da Arce reconhece que houve ineficiência da Cagece em relação à tarifa de contingência na aplicação dos recursos obtidos em projetos, embora não tenham sido mencionados quais instrumentos de análises a agência reguladora avistou para regular a companhia em períodos de eventos extremos. Para o entrevistado da Arsesp, há o reconhecimento de que ainda falta esta ação concreta por parte da agência reguladora na formulação de medidas mais eficazes ao considerar as mudanças climáticas. Há acompanhamentos por parte das agências reguladoras, assim como das companhias, em relação à vazão dos mananciais de distribuição de água, e estas ações são compreendidas, pelos entrevistados, como medida mitigatória para melhorar a eficiência dos serviços para a população atendida. Para elucidar os achados, o Quadro 13 traz uma síntese das entrevistas transcritas. 
Quadro 13 - Percepções dos entrevistados sobre a ineficiência do setor de saneamento básico considerando as mudancas climáticas

\begin{tabular}{|c|c|c|c|c|c|c|c|}
\hline \multirow{3}{*}{$\begin{array}{c}\text { Assuntos } \\
\text { Abordados }\end{array}$} & \multicolumn{7}{|c|}{ Percepções dos entrevistados } \\
\hline & \multicolumn{3}{|c|}{ Operadores de água e esgotamento sanitário } & \multicolumn{2}{|c|}{ Agências reguladoras } & \multicolumn{2}{|c|}{ Organizações da Sociedade Civil } \\
\hline & Cagece & Sabesp & Instituto Sisar & Arce & Arsesp & Elo/Amigo - ASA & $\begin{array}{c}\text { SOS Mata } \\
\text { Atlântica }\end{array}$ \\
\hline $\begin{array}{l}\text { Quão importante } \\
\text { é discutir ações } \\
\text { de redução de } \\
\text { perdas de água } \\
\text { nos sistemas de } \\
\text { distribuição? }\end{array}$ & $\begin{array}{l}\text { Elencam as } \\
\text { perdas de água } \\
\text { como principal } \\
\text { fator associado à } \\
\text { eficiência hídrica }\end{array}$ & $\begin{array}{l}\text { Houve uma } \\
\text { divergência } \\
\text { sobre classificar } \\
\text { as perdas de } \\
\text { água como fator } \\
\text { importante; no } \\
\text { geral foi } \\
\text { identificado que } \\
\text { as perdas de } \\
\text { água é o } \\
\text { principal fator } \\
\text { associado à } \\
\text { eficiência } \\
\text { hídrica }\end{array}$ & Não foi citado & Não foi citado & $\begin{array}{l}\text { Elenca o } \\
\text { aprimoramento do } \\
\text { controle de perdas } \\
\text { e a recuperação da } \\
\text { qualidade dos } \\
\text { recursos hídricos } \\
\text { como fatores } \\
\text { associados à } \\
\text { eficiência hídrica }\end{array}$ & Não foi citado & $\begin{array}{l}\text { Elenca as perdas } \\
\text { de água como um } \\
\text { dos principais } \\
\text { fatores associados } \\
\text { à eficiência } \\
\text { hídrica }\end{array}$ \\
\hline
\end{tabular}




\begin{tabular}{|c|c|c|c|c|c|c|c|}
\hline \multirow{3}{*}{$\begin{array}{c}\text { Assuntos } \\
\text { Abordados }\end{array}$} & \multicolumn{7}{|c|}{ Percepções dos entrevistados } \\
\hline & \multicolumn{3}{|c|}{ Operadores de água e esgotamento sanitário } & \multicolumn{2}{|c|}{ Agências reguladoras } & \multicolumn{2}{|c|}{ Organizações da Sociedade Civil } \\
\hline & Cagece & Sabesp & Instituto Sisar & Arce & Arsesp & Elo/Amigo - ASA & $\begin{array}{l}\text { SOS Mata } \\
\text { Atlântica }\end{array}$ \\
\hline
\end{tabular}

Fonte: Elaboração do autor 


\section{CAPÍTULO 5 - DISCUSSÕES}

Neste capítulo procura-se responder as indagações norteadoras da pesquisa, que foram bases na condução das análises dos resultados, com foco, sobretudo, em elucidar como as mudanças climáticas têm sido internalizadas pelo setor de saneamento básico nos dois estados estudados.

Os documentos analisados mostram que as companhias estaduais de saneamento básico de São Paulo e Ceará tratam os fenômenos relacionados às mudanças climáticas a partir, sobretudo, das secas prolongadas. Os relatórios públicos da Cagece evidenciam que o fenômeno da seca é tratado como inerente ao estado do Ceará, reconhecendo que a estiagem de 2012 a 2018 causou impactos distintos para a população (SILVEIRA et al., 2018) e para a companhia, principalmente no que tange ao aumento de tarifa e à ausência de recursos hídricos em algumas regiões do estado. Não se identificou, na análise dos documentos, um discurso especificamente focado sobre mudanças climáticas, tampouco se atribuiu à estiagem prolongada como uma possível mudança do clima provocada pela interferência antrópica. No Relatório de Gestão de 2015 a 2018 ressalta-se a participação da companhia no Grupo de Contingência, que também tem a presença da Fundação Cearense de Meteorologia e Recursos Hídricos. Assim, embora os documentos não mostrem claramente, é possível endossar que a Cagece participa de discussões sobre as secas no estado com foco em ações adaptativas em relação ao acesso à água.

Nesse sentido, as ações mostradas em relação ao enfrentamento da seca passam por mais eficiência técnica e de gestão por parte da companhia, que necessita de recursos vultosos para o sucesso das atividades, como reduzir as perdas de água no sistema de distribuição da companhia (SIEGEL, 2017). Como a análise dos documentos evidencia, sendo a escassez do recurso hídrico a maior preocupação da companhia, os relatórios focam no projeto de dessalinização como saída para o enfrentamento da seca e resolução do problema de demanda na Região Metropolitana de Fortaleza. Não é possível sinalizar, nos documentos, atenção a outros modelos alternativos de abastecimento que a companhia estuda adotar para outras regiões do estado em que a dessalinização não será possível, ao considerar que o semiárido caminha para desertificação nos próximos anos. 
Esta análise dos documentos permite identificar que a seca prolongada de 2012 a 2018 trouxe novas reflexões para a companhia do ponto de vista de gestão e estratégias operacionais. Ainda que não haja relação direta da seca prolongada com as mudanças climáticas, as ações para abastecimento de água nos municípios atendidos pela Cagece consideram a intensificação da seca, atribuindo a perspectiva de "convivência". Neste sentido, é possível aferir que o estado do Ceará está mais atento à questão climática em relação aos órgãos que compõem o setor de saneamento básico.

Já no caso dos documentos analisados para o estado de São Paulo, é possível verificar que para a Sabesp as mudanças climáticas são tratadas, sobretudo, a partir das ações mitigatórias de emissão de gases de efeito estufa, reconhecendo que a emissão de gases poluentes contribui negativamente para o clima. Desde o primeiro Relatório de Sustentabilidade, em 2012, analisado para esta dissertação, identifica-se a divulgação de capítulos sobre as emissões de GEE pela companhia e quais medidas são tomadas em consonância com as propostas articuladas pelos relatórios do IPCC e pelas ações concebidas nas reuniões das COPs, das quais espera-se que o setor produtivo também repense sua produção e contribuição no cumprimento das metas em relação às medidas de adaptação e mitigação (RODRIGUES FILHO et al., 2016; DE MORAIS, 2019).

Ainda anterior à seca de 2013-2015 no estado de São Paulo, observa-se que a Sabesp não faz menções claras a possíveis períodos de estiagens no futuro; há alusões sobre disponibilidade hídrica em cenários de escassez hídrica sem associação com alguma indicação de cenário de seca nos anos seguintes (2013, 2014 e 2015), tampouco projeções para as próximas décadas. Como apontado por AMBRIZZI et al. (2019), os eventos extremos climáticos no estado de São Paulo estão mais associados à alta precipitação, sendo assim, o cenário de escassez hídrica apresentado no Relatório de Sustentabilidade anterior à seca prolongada é conservador do ponto de vista de entender este risco como fator iminente. Como não é identificado um evento extremo climático relacionado à seca de longa duração em um período anterior a 2012 no estado de São Paulo, a percepção deste risco para a companhia pode estar relacionada com as ideias de DERYUGINA (2013), de que os eventos de longa duração, e recentes, têm mais propensão de modificar o nível de percepção dos indivíduos do que eventos longínquos. 
A partir do segundo período dos relatórios analisados da Sabesp, é possível identificar que a companhia se vê diante de um cenário inesperado de estiagem que afeta diretamente os mananciais dos quais é responsável pelo gerenciamento. A estiagem se traduz em ações focadas na segurança hídrica, com realocação de investimentos para obras hídricas emergenciais, confluindo com o processo adaptativo coetâneo trazido por BRYANT et al. (2000) e DE MORAIS (2019), por exemplo. Ressalta-se que, durante o período de estiagem, a preocupação maior evidenciada nos documentos analisados está na RMSP, mais do que no litoral e no interior, regiões em que a Sabesp também tem operação dos serviços de água e esgoto, e que também foram impactadas pela estiagem do Sudeste (MARENGO et al., 2015).

Por se tratar de documentos que são encaminhados aos stakeholders, acionistas e estão disponíveis para a população como um todo (CAMPOS et al., 2013), os Relatórios de Sustentabilidade da Sabesp analisados mostram que as ações propostas e executadas estão minimamente integradas com outros órgãos públicos, mesmo no que concerne ao reconhecimento dos impactos das mudanças climáticas. A segurança hídrica é constantemente traduzida em obras de engenharia, com algumas inserções sobre projetos de reúso, não avistando soluções diferentes das apontadas nos relatórios constantemente (CABRAL, 2017), o que coloca em dúvida a maneira como a companhia vai enfrentar os possíveis novos eventos extremos climáticos. Ainda que nos relatórios do terceiro período analisado, a Sabesp considere que a segurança hídrica está garantida para o futuro em caso de novas estiagens com a construção de novas obras hídricas, não há menção de projeções de cenários futuros em relação aos impactos das mudanças climáticas. Há apenas menções sobre oferta e demanda considerando o acréscimo populacional das próprias décadas.

Já a análise das transcrições das entrevistas endossa que as mudanças climáticas são temas observados por representantes das companhias estaduais e do Instituto Sisar (responsável pelo saneamento rural no Ceará) na medida em que recorrem a algum evento climático extremo recente, correlacionando o acontecimento em si com as mudanças climáticas. As projeções estimadas pelo IPCC de aquecimento na ordem de $1,5^{\circ} \mathrm{C}$ a $2^{\circ} \mathrm{C}$ não são citadas durante as entrevistas quando relacionadas aos eventos de seca prolongada, assim como nenhuma projeção referente aos estados é mencionada. Como observado nos capítulos anteriores da dissertação, as análises dos dados extraídos de XAVIER et al. (2015) para os dois estados São Paulo e Ceará apontaram um acréscimo na temperatura média de $0,14^{\circ} \mathrm{C}$ e 
0,29 $\mathrm{C}$ por década desde 1980 a 2015, respectivamente; contudo a percepção dos entrevistados acerca dos eventos de seca não consideram estas mudanças gradativas, o que permite endossar que os eventos de seca prolongada somente são reconhecidos por eles como situações pontuais.

A observação das mudanças climáticas a partir da alta precipitação é feita quando os entrevistados são estimulados pelas perguntas trazidas pelo entrevistador, isto é, não surgem de maneira espontânea. Isso corrobora com o fato de que as secas estão mais entrelaçadas às percepções sobre mudanças climáticas do que as chuvas de alta intensidade em períodos curtos. Ainda que isso ocorra, o impacto da alta precipitação é observado, pelos entrevistados, apenas quanto ao funcionamento das estruturas físicas dos sistemas de saneamento básico, reforçando a observação de BRITTO et al. (2010) sobre os impactos das mudanças climáticas no Rio de Janeiro. Em outras palavras, o impacto aos sistemas físicos da operação de água e esgotamento sanitário não é apontado como risco para a sociedade ao ser correlacionado com as mudanças do clima, já que os entrevistados evidenciam confiança em relação à resiliência dos serviços prestados pelas companhias de saneamento básico de ambos os estados.

Para os agentes reguladores entrevistados, as análises das entrevistas evidenciam uma percepção semelhante aos representantes das companhias estaduais de saneamento básico dos dois estados. O fator cultural é trazido à tona pelo entrevistado da Arce, quando este recorre ao histórico familiar para assimilar às mudanças climáticas ao seu entendimento sobre o assunto, endossando, como sustenta WEBER (2010), que as percepções de riscos estão diretamente associadas aos fatores psicológicos e culturais de cada indivíduo. Ao lembrar-se dos momentos de infância, o entrevistado estabelece uma perspectiva sobre mudanças climáticas de forma mais afetiva e contextualiza a seca prolongada do Ceará como um fator de risco para a demanda hídrica da região. Contudo, na sua visão, isso não significa que este risco está transposto para todo o setor de saneamento básico, pois assim como BRITTO et al. (2010) discutem, os recursos hídricos, enquanto demanda e oferta de água para sociedade, estão mais interligados na discussão climática do que o saneamento básico do ponto de vista do esgotamento sanitário.

A observação das mudanças climáticas por parte do entrevistado da Arsesp se coloca desde uma perspectiva mais técnica, baseada em conceitos científicos identificados no currículo acadêmico e profissional do entrevistado, que já trabalhou com assuntos similares 
em pesquisas. A vivência com a seca de 2013 a 2015 no estado de São Paulo consolidou a construção de sua percepção sobre as mudanças climáticas, mas foram registradas como "mudanças hidrológicas” durante a entrevista, portanto, a demanda e oferta da água mais uma vez surgem como centro de preocupações perante os riscos impulsionados pelas mudanças climáticas ao saneamento básico.

Quanto aos profissionais do terceiro setor, mesmo que não componham o setor de saneamento básico na essência da operação, as suas narrativas sobre a mudança climática endossam seu entendimento sobre os fenômenos climáticos e como os mesmos estão relacionados ao setor de saneamento básico. A construção do campo perceptivo desses entrevistados se assemelha ao conceito de existência de ameaças objetivas do mundo real, como as mudanças observadas no clima, e a percepção subjetiva de avaliação dessas ameaças (ROSA, 2003; VAN DER LINDEN, 2017; DI GIULIO, 2015). Por não serem atores ligados diretamente a funções de cargos públicos ou privados, portanto sem a prerrogativa de prestarem contas para a sociedade ou acionistas, é possível aferir que ambos os entrevistados das organizações do Terceiro Setor do Ceará e São Paulo consideram ações adaptativas e mitigatórias às mudanças climáticas como objetivos importantes, inclusive de suas atuações, reforçando como suas percepções estão ancoradas em valores sócio altruísticos e biosféricos, apresentados por SHI et al. (2016). Em outras palavras, suas narrativas endossam a preocupação com o bem-estar alheio e com a identificação da natureza e do meio ambiente como instrumentos importantes para a humanidade. As opiniões acerca das mudanças climáticas, seus riscos e seus impactos ao setor de saneamento são moldadas a partir de suas experiências de vida e crenças, endossando questões como injustiças sociais, principalmente ao refletirem sobre os impactos da não disponibilidade hídrica para comunidades mais vulneráveis (WEBER, 2010; RENN, 2008).

Ao analisar os resultados sobre análise de documentos para situar as reações do setor de saneamento aos impactos das mudanças climáticas, é possível observar que, ao comparar o passado recente dos eventos extremos climáticos relacionados à seca nos dois estados, a reação do setor do saneamento básico no Ceará e São Paulo se resume a ações de intervenções imediatas por meio de obras hídricas. Como endossam OATES et al. (2014) sobre as soluções adaptativas para o setor de saneamento básico às mudanças climáticas, observa-se que as companhias estaduais, mesmo reconhecendo o fenômeno climático, se preparam de maneira 
convencional para os impactos trazidos pela ocorrência dos eventos extremos climáticos, assim como observado por DI GIULIO et al. (2019) ao discutirem as ações adaptativas nas políticas públicas nas capitais de alguns estados brasileiros. No Ceará, ao considerar a seca como fenômeno inerente à região, a Cagece demonstra constantemente nos documentos que a crise hídrica nos municípios cearenses é o risco mais iminente para a sociedade, e também para ela enquanto negócio, o que faz a companhia listar uma série de obras emergenciais, como apontadas anteriormente no Capítulo 4. Já no caso da Sabesp, os documentos analisados endossam que a companhia enxerga a escassez hídrica como risco, e cita os diversos projetos de engenharia e investimentos em obras hídricas, sobretudo no período de 2014 a 2015, com a intensificação da seca a partir de 2013. É observado ainda, no caso da Sabesp, que a obra de interligação do Sistema Produtor São Lourenço já era citada no primeiro período (2012), isso significa que a companhia identificava um problema de oferta e demanda para a RMSP, mesmo que isso não estivesse relacionado diretamente com possíveis impactos de mudanças climáticas.

As ideias de OATES et al. (2014) sobre como as companhias de saneamento escolhem fontes de abastecimento de água menos vulneráveis a variações causadas por mudanças climáticas, por aumento da competição pela água ou por outros fatores, não correspondem ao observado na análise dos relatórios de sustentabilidade e de gestão das companhias estaduais. Nestes, os métodos hídricos de preparação para as mudanças climáticas se baseiam unicamente em fontes de abastecimento dependentes de chuva, como os mananciais superficiais. Claramente são identificados projetos de reuso em São Paulo e o edital de dessalinização no Ceará, o que reflete os impactos que as companhias tiveram com as secas prolongadas; no entanto, por se tratarem de projetos complexos e economicamente vultosos, não é possível aferir que estas medidas serão suficientes para adaptação frente aos impactos dos eventos extremos climáticos.

Os dados trazidos pelo IBGE (2019), como colocados no Capítulo 3, refletem a perspectiva de crescimento populacional nos dois estados até 2060, embora haja uma deflação na última década analisada. Ao considerar as projeções climáticas para ambos os estados, com aumentos substanciais de $1,5^{\circ} \mathrm{C}$ a $2,5^{\circ} \mathrm{C}$ podendo ser mais elevado em algumas cidades, compreende-se, portanto, que as ações preparatórias aos impactos climáticos e ao crescimento populacional precisam estar mais presentes nas estratégias divulgadas por estas companhias 
estaduais. RODRIGUES FILHO et al., (2016) identificam que as consequências do efeito do aquecimento pelas ações antrópicas já são sentidas por todos, e, consequentemente, o setor produtivo também é impactado; isto já é refletido pelo setor do saneamento básico com a ocorrência de extremos climáticos, principalmente com as secas prolongadas, o que reforça ainda mais as ideias propostas por OATES et al. (2014), que visualizam a necessidade de um fortalecimento na governança e nos sistemas inserindo o contexto climático como risco prioritário.

Já a análise das entrevistas reforça que as respostas do setor de saneamento básico do Ceará e São Paulo aos impactos das mudanças climáticas estão relacionadas aos riscos identificados pelos atores entrevistados durante os eventos de seca prolongada da década de 2010. Estes riscos são abordados pelos entrevistados a partir da ineficiência do setor de saneamento, de maneira generalizada, em se preparar para os impactos negativos em relação às mudanças climáticas. É possível identificar que os atores das companhias estaduais e do Instituto Sisar apontam que o saneamento básico responde muito lentamente aos riscos das mudanças climáticas, pois há outras variáveis a serem consideradas. Não diferentemente do que foi encontrado na análise documental, os entrevistados focaram na realização de obras hídricas como respostas às mudanças climáticas, também atribuindo as obras emergenciais como pontos relevantes na condução das secas prolongadas nos dois estados no passado. Os atores das companhias estaduais reforçam que a absorção dos impactos das mudanças climáticas por parte da sociedade é um ponto relevante na construção dos processos adaptativos, particularmente por meio das obras hídricas que têm o objetivo de impedir a interrupção do fornecimento de água.

O preço da água é uma resposta direta aos impactos das mudanças climáticas como observou os entrevistados também das agências reguladoras, bem como das organizações do Terceiro Setor. Tais medidas vão na contramão de um processo de adaptação sustentável como reforça Brown (2011), que destaca a integração ambiental e a equidade social como fatores fundamentais nas respostas às mudanças do clima. $\mathrm{O}$ valor monetário atribuído aos serviços de distribuição de água ainda é compreendido pelos representantes das companhias estaduais e das agências reguladoras como um ponto a ser trabalhado de maneira mais assertiva na expectativa de que a população reconheça os esforços realizados na garantia da segurança hídrica. 
Como abordado no capítulo anterior, sobre a ineficiência na gestão do saneamento básico, percebe-se também, na análise das entrevistas, a dificuldade de implementação de indicadores relacionados às mudanças climáticas como resposta aos futuros impactos dada à complexidade do setor de saneamento básico no Brasil, não somente nos estados estudados. Como identificado nos capítulos anteriores, a Lei de Diretrizes Nacionais do Saneamento e o próprio Plano Nacional de Saneamento Básico (PLANSAB) não incluíram variáveis climáticas para a construção de suas diretrizes, portanto, o que se observa, na prática, são apenas ferramentas emergenciais aplicadas na governança e na engenharia das companhias de saneamento quando o setor é impactado diretamente com os eventos extremos climáticos.

Mesmo que as secas prolongadas tenham acontecido recentemente nos dois estados, os entrevistados demonstram que a resposta do saneamento básico perante as mudanças climáticas deverá seguir de maneira convencional, por meio de realização de obras emergenciais de infraestrutura cinza. Essa constatação vai ao encontro das ideias discutidas por BORICK et al. (2010) e BRULLE et al. (2012) sobre as lacunas que existem entre as percepções individuais sobre as mudanças climáticas e as ações reais. O setor do saneamento básico no Brasil escancara a desigualdade social do país, em que locais mais vulneráveis carecem da infraestrutura básica de acesso à água e esgotamento sanitário, evidenciando que há defasagem nas políticas de saneamento elaboradas, em que os investimentos têm sido alocados para poucas regiões do país, sobretudo com predomínio no Sudeste (SAIANI et al., 2010). O planejamento em saneamento básico se distancia das companhias de saneamento à medida que as companhias de saneamento básico atuam como executoras dos serviços de abastecimento de água e coleta de esgoto. A ausência de um detalhamento mais crítico da agenda climática dentro do setor de saneamento analisado, como constatado nesta pesquisa, reforça este distanciamento encontrado entre o planejamento das estratégias e a execução das ações para este setor.

Para elucidar os achados, o Quadro 14 sintetiza as intersecções encontradas entre os Relatórios de Sustentabilidade (ou de Relatório de Gestão) e as entrevistas com os atores sociais. 
Quadro 14 - Intersecções entre os Relatórios de Sustentabilidade (ou Relatório de Gestão) e as entrevistas realizadas

\begin{tabular}{|c|c|c|}
\hline Tópicos & São Paulo (Sabesp/Arsesp/SOS Mata Atlântica) & Ceará (Cagece/Arce/Instituto Sisar/EloAmigo) \\
\hline Mudanças Climáticas e & $\begin{array}{l}\text { As mudanças climáticas são citadas em todos os } \\
\text { Relatórios de Sustentabilidade da Sabesp, mas com } \\
\text { abordagens diferentes em cada edição. Nos relatórios } \\
\text { de } 2013 \text { a } 2015 \text {, a seca é relacionada ao efeito das } \\
\text { mudanças do clima, assim como as entrevistas com os } \\
\text { indivíduos da Sabesp, que partem da seca para } \\
\text { tratarem sobre mudanças climáticas. Os discursos } \\
\text { encontrados nas entrevistas semiestruturadas com os } \\
\text { agentes reguladores se assemelham aos achados nos } \\
\text { Relatórios de Sustentabilidade sobre como o setor de } \\
\text { saneamento no estado de São Paulo parece enxergar as } \\
\text { mudanças climáticas. Nos documentos analisados da } \\
\text { Sabesp, não foram feitas análises sobre o clima em } \\
\text { décadas passadas para que fossem estabelecidas metas } \\
\text { para o futuro, assim como nas entrevistas também não } \\
\text { há uma tentativa dos atores em estabelecer uma linha } \\
\text { temporal das mudanças climáticas ao situarem seus } \\
\text { entendimentos e percepções sobre o fenômeno. A }\end{array}$ & $\begin{array}{l}\text { O Relatório de Sustentabilidade de } 2017 \text { e o Relatório } \\
\text { de Gestão de } 2015 \text { a } 2018 \text { destacam a seca e estiagem } \\
\text { constantemente, mas a relação desses eventos com as } \\
\text { mudanças climáticas não é estabelecida diretamente. } \\
\text { Diferentemente dos entrevistados da empresa de } \\
\text { saneamento que consideram os riscos da seca como uma } \\
\text { das respostas das mudanças climáticas, ainda que } \\
\text { ressaltem a perspectiva de convivência com a seca no } \\
\text { estado. Os documentos analisados não trazem projeções } \\
\text { sobre o futuro climático da Região Nordeste ou do } \\
\text { Ceará; já as entrevistas dão pistas de que, para os atores } \\
\text { sociais, o clima é um fator constantemente observado } \\
\text { pela Cagece para que ela possa pensar em estratégias } \\
\text { mais assertivas. A narrativa do ator do Terceiro setor } \\
\text { não é tão diferente dos atores do saneamento básico do } \\
\text { Ceará, mas há elementos importantes, que não foram } \\
\text { observados nas outras entrevistas ou nos documentos } \\
\text { analisados da Cagece. Particularmente o fato de que o }\end{array}$ \\
\hline
\end{tabular}




\begin{tabular}{|c|c|c|}
\hline Tópicos & São Paulo (Sabesp/Arsesp/SOS Mata Atlântica) & Ceará (Cagece/Arce/Instituto Sisar/EloAmigo) \\
\hline & $\begin{array}{l}\text { narrativa captada pelo ator do Terceiro Setor é } \\
\text { diferente, já que há uma percepção de que as } \\
\text { mudanças climáticas estão diretamente ligadas aos } \\
\text { objetivos e metas das organizações nas quais atuam. } \\
\text { Estes atores também fazem críticas sobre como o setor } \\
\text { de saneamento conduz o tema de mudanças climáticas } \\
\text { internamente. }\end{array}$ & $\begin{array}{l}\text { entendimento e as percepções sobre mudanças } \\
\text { climáticas, os riscos e os impactos ao setor de } \\
\text { saneamento estão amparados a partir das experiências } \\
\text { de vida e crenças, endossando questões como injustiças } \\
\text { sociais, principalmente relacionadas aos impactos da } \\
\text { não disponibilidade hídrica para comunidades mais } \\
\text { vulneráveis. }\end{array}$ \\
\hline Adaptação & $\begin{array}{l}\text { O conceito de adaptação às mudanças climáticas é } \\
\text { tratado nos Relatórios de } 2013 \text { a } 2015 \text {, ainda que não } \\
\text { diretamente ancorado nesse termo. Entende-se que as } \\
\text { obras de interligação de reservatórios, os trabalhos de } \\
\text { redução das perdas nos sistemas de distribuição, a } \\
\text { implantação do bônus para diminuição de consumo são } \\
\text { perspectivas adaptativas utilizadas pela Sabesp como } \\
\text { resposta à crise hídrica de } 2013 \text { a } 2015 \text {. }\end{array}$ & $\begin{array}{l}\text { O conceito de adaptação às mudanças climáticas } \\
\text { também é tratado nos dois documentos analisados, mas } \\
\text { não diretamente ancorado ao termo. Entende-se que as } \\
\text { obras de interligação de açudes, os trabalhos de redução } \\
\text { das perdas nos sistemas de distribuição e o projeto de } \\
\text { dessalinização da Região Metropolitana de Fortaleza são } \\
\text { exemplos de estratégias adaptativas utilizados pela } \\
\text { Cagece como resposta à seca prolongada de } 2012 \text { a } \\
2018 \text {. }\end{array}$ \\
\hline Mitigação & $\begin{array}{l}\text { O conceito de mitigação não foi abordado pelos } \\
\text { entrevistados da Sabesp; contudo, é tratado nos } \\
\text { Relatórios de Sustentabilidade de 2012-2018 (períodos }\end{array}$ & $\begin{array}{l}\text { Nos documentos analisados e nas entrevistas realizadas } \\
\text { não há menções sobre ações mitigatórias, como foi } \\
\text { observado nos documentos da Sabesp. }\end{array}$ \\
\hline
\end{tabular}




\begin{tabular}{|l|l|c|}
\hline Tópicos & \multicolumn{1}{|c|}{ São Paulo (Sabesp/Arsesp/SOS Mata Atlântica) } & Ceará (Cagece/Arce/Instituto Sisar/EloAmigo) \\
\hline & $\begin{array}{l}\text { analisados), ao apresentarem projetos de redução de } \\
\text { GEE nas estações de tratamento de água e esgoto. }\end{array}$ & \\
\hline
\end{tabular}




\section{CAPÍTULO 6 - CONSIDERAÇÕES FINAIS}

A realização deste estudo e sua relevância emergem a medida que os serviços de água e esgotamento sanitário no Brasil adentram em mais uma década de incertezas perante os investimentos necessários para a expansão do saneamento básico no país e com metas de universalização a serem cumpridas nos próximos anos (2030 - ODS 6; 2033 - PLANSAB). Compreender como os fenômenos associados às mudanças climáticas interagem com os demais desafios que o setor do saneamento tem é uma atividade urgente e necessária. Os resultados e discussões propostos nesta dissertação buscaram oferecer um panorama sobre como estas questões têm sido tratadas em dois estados brasileiros, cada qual a partir de suas características e especificidades. Espera-se que esse panorama auxilie o setor de saneamento no Brasil a introduzir e aplicar uma agenda focada nas mudanças climáticas, para além de ações esporádicas para lidar com episódios específicos relacionados aos eventos extremos climáticos, seja pelas secas prolongadas ou pelas intensas precipitações.

Nesta dissertação, os resultados evidenciam que a agenda climática somente se apresenta no plano emergencial aos acontecimentos de seca no Ceará (2012 a 2018) e São Paulo (2013 a 2015). Tal agenda, contudo, não repercute as tendências para ambos os estados em termos de projeções de aumento de temperatura, fato preocupante para as próximas décadas, já que essas localidades já apresentaram aumento de temperatura média nas últimas três décadas e meia, de $1^{\circ} \mathrm{C}$ (no caso do Ceará) e $0,5^{\circ}$ (para São Paulo). Compreende-se que há ações feitas em curso, contudo estas não são necessariamente planejadas à luz de uma abordagem multidimensional de sustentabilidade, considerando aspectos ambientais, econômicos, sociais, culturais, espaciais e políticos. Particularmente frente aos desafios climáticos, questiona-se sobre como essas ações podem efetivamente economizar recursos financeiros, alcançar os grupos sociais mais vulneráveis e terem uma garantia de durabilidade do ponto de vista de infraestrutura.

Cabe destacar que a dissertação não buscou fazer comparações sobre a agenda climática e as respostas construídas pelo setor de saneamento nos estados estudados; o objetivo foi, a partir de um levantamento sobre como esses estados agiram, pensaram e planejaram em face de ocorrências similares de extremos climáticos na década de 2010, compreender como a 
agenda climática tem sido moldada em um setor que, historicamente, enfrenta importantes desafios. À medida que os impactos das mudanças climáticas surgem com mais veemência no país, estados-chaves de suas regiões, como Ceará e São Paulo, têm papéis importantes na construção de uma agenda do tema em consonância com o saneamento básico, atualmente ainda findado em ações de engenharia e discussões legislativas sobre abertura de mercado para ampliação de operações.

Como os resultados alcançados endossam, e é possível extrapolá-los para outros estados brasileiros, a escassez hídrica ainda é o pilar mais reconhecido pelos próprios atores mais diretamente envolvidos no setor, que enxergam riscos iminentes para a operação dos serviços no futuro e para os negócios, mesmo que esta escassez não esteja associada às mudanças climáticas. Neste sentido, reconhece-se a necessidade de os atores envolvidos com o saneamento básico incorporarem as mudanças climáticas em suas atividades nos departamentos das companhias de saneamento ou nas agências reguladoras, internalizando as projeções climáticas globais de aquecimento de $1,5^{\circ} \mathrm{C}$ a $2^{\circ} \mathrm{C}$ e as projeções regionais, que irão impactar a oferta e demanda de água no futuro. O setor de saneamento básico dos dois estados precisa, com urgência, empreender mais esforços para compreender os impactos à infraestrutura de abastecimento de água e sanitária a partir dos eventos extremos climáticos, particularmente diante da escassez hídrica com secas prolongadas e dos danos às estruturas das ETAs e ETEs com as chuvas intensas devido à subdimensão das mesmas, ou ligações irregulares da população nas estruturas de drenagem. A degradação dos afluentes no Brasil rios, córregos, riachos, entre outros (SNIS, 2018) - traduz a ausência de planejamento das companhias de saneamento básico - públicas ou privadas. O que foi observado nesta dissertação é que os poucos projetos citados durante as entrevistas, com destaque para a recuperação do Rio Pinheiros no município de São Paulo, não estão atrelados aos riscos de escassez hídrica, em que o recurso hídrico destes mesmos afluentes se somaria aos mananciais superficiais e subterrâneos, além de outras tecnologias, para que fosse garantida mais disponibilidade hídrica. A preocupação atual dos agentes do setor de saneamento do Ceará e São Paulo se resume ainda em ter mais quantidade de água para que as operações não sejam afetadas, mesmo que mais esgotos sejam gerados e pouco seja feito para que os efluentes não poluam mais os corpos hídricos e ofereçam mais riscos à sociedade em relação à saúde.

Apesar dos importantes resultados alcançados e discutidos nesta dissertação, reconhecese como principal limitação do estudo realizado a captação de percepções de outros atores 
ligados ao saneamento básico, como gestores do poder executivo municipais, secretarias estaduais de recursos hídricos e/ou meio ambiente e departamentos que outorgam o uso da água para consumo. Estudos nos níveis municipais mais aprofundados podem complementar o entendimento sobre as razões pelas quais o setor do saneamento básico ainda resiste em adicionar práticas voltadas às mudanças climáticas na agenda diária de ações de planejamento e engenharia. Outra limitação identificada ao longo da pesquisa foi de cruzar dados sobre a oferta e demanda de água dos dois estados a partir das projeções climáticas encontradas, isso pode ser alcançado em estudos específicos para as regiões do país, considerando os apontamentos dos relatórios técnicos climáticos que fazem projeções para as próximas décadas e os relatórios técnicos de hidrologia. A última limitação apontada é sobre cenários, considerando o uso da água para indústria, agricultura e outros fins, frente às projeções de aumento da temperatura. Avalia-se que ainda há poucos estudos acadêmicos no Brasil que façam a conexão das mudanças climáticas com o saneamento básico na perspectiva do acesso aos serviços e o impacto para as populações.

Os resultados apresentados e discutidos nesta dissertação permitem fazer recomendações para que o setor de saneamento básico no Brasil integre as mudanças climáticas nas estratégias de negócio adotando as seguintes ações e diretrizes, também discutidas em análises de outros autores (DIAZ et al., 2014; OATES et al., 2014; YANG et al., 2017:

i) Compreender as vulnerabilidades causadas pelas mudanças climáticas nos territórios de operação dos serviços de água e esgoto;

ii) Incluir nos planejamentos de operação e investimentos o histórico de variabilidade climática das últimas décadas disponível para que haja compreensão dos impactos causados pelos eventos climáticos extremos do passado;

iii) Incluir a variável climática nos investimentos necessários, em termos de recursos financeiros, das operações dos sistemas de saneamento básico;

iv) Incluir as projeções climáticas sobre cenários futuros para que as operações não sejam afetadas;

v) Criar planos de redução de emissão de gases poluentes, sobretudo gás metano $\left(\mathrm{CH}_{4}\right)$ nas estações de tratamento de esgoto; 
vi) E, finalmente, garantir que os investimentos pelas companhias de saneamento sejam alocados para a resiliência do abastecimento de água para consumo humano, manutenção dos sistemas de operação e ampliação da coleta e tratamento de esgoto. 


\section{REFERÊNCIAS BIBLIOGRÁFICAS}

ABCON (Associação Brasileira das Concessionárias Privadas de Serviços Públicos de Água e Esgoto). Panorama da participação privada no Saneamento. São Paulo, 2019.

AGÊNCIA NACIONAL DAS ÁGUAS (Brasil). Atlas Brasil: abastecimento urbano de água: panorama nacional. Agência Nacional das Águas; Engecorps/Cobrape. Brasília, 2010.

ALBUQUERQUE NETO, V. S. Análise do Sisar como uma alternativa financeiramente sustentável para o saneamento rural no Ceará. 2011. 74f. Dissertação (mestrado profissional) - Programa de Pós Graduação em Economia, CAEN, Universidade Federal do Ceará, Fortaleza, CE, 2011.

AMBRIZZI, T. et al. Sumário Executivo do Volume 1 - Base Científica das Mudanças Climáticas. Contribuição do Grupo de Trabalho 1 para o $1^{\circ}$ Relatório de Avaliação Nacional do Painel Brasileiro de Mudanças Climáticas. PBMC, Rio de Janeiro, Brasil, 2012.

Eventos Extremos no Estado de São Paulo. In: JACOBI, P. R; TRANI, E. Planejando o Futuro Hoje: ODS 13, Adaptação e Mudanças Climáticas em São Paulo. Pg. 39-42. 2019.

AQUINO, A. L. A. et al. Mudanças Climáticas e a Saúde no Brasil: O Acordo de Paris. In: $6^{\circ}$ Congresso Internacional em Saúde. 2019.

ARNELL, N. Incorporating Climate Change Into Water Resources Planning in England and Wales1. England. JAWRA Journal of the American Water Resources Association. 47. $541-549.2011$. 
ARTAXO, P. Cenários para os serviços ecossistêmicos de São Paulo com as mudanças climáticas. In: JACOBI, P. R; TRANI, E. Planejando o Futuro Hoje: ODS 13, Adaptação e Mudanças Climáticas em São Paulo. Pg. 9-11. 2019.

BAENINGER, R.A. Interiorização da migração em São Paulo: novas territorialidades e novos desafios teóricos. In: Anais do XIV Encontro Nacional de Estudos Populacionais, 2024 de setembro de 2004, Caxambu-MG, ABEP. 2004.

BARROSO, Luis Roberto. Agências Reguladoras. Constituição e transformações do Estado e Legitimidade Democrática. Revista de Direito Administrativo, Rio de Janeiro, v. 229, p. 285-312, jul. 2002. Disponível em: <http://bibliotecadigital.fgv.br/ojs/index.php/rda/article/view/46445>. Acessado em: 18 de Fevereiro de 2020.

BILOTTA, P. et al. Estimativa de geração de energia e emissão evitada de gás de efeito estufa na recuperação de biogás produzido em estação de tratamento de esgotos. Eng. Sanit. Ambient. [online]. 2016, vol.21, n.2, pg. 275-282. Epub June 20, 2016.

BORICK, C.P. et al. A reason to believe: examining the factors that determine individual views on global warming. Soc Sci Q 91(3):777-800. 2010.

BOSHER, L. et al. Integrating disaster risk management into construction: A UK perspective. Build. Res. Inf. 35, pg. 163-177. 2007.

BRASIL. Secretaria Nacional de Saneamento Ambiental Sistema Nacional de Informações sobre Saneamento: Diagnóstico dos Serviços de Água e Esgotos - 2011. - Brasília: MCIDADES.SNSA, 2013.

Ministério das Cidades. Secretaria Nacional de Saneamento Ambiental - SNSA. Sistema Nacional de Informações sobre Saneamento: Diagnóstico dos Serviços de Água e Esgotos - 2012. Brasília: SNSA/MCIDADES. 164 p. : il. 2014. 
Ministério das Cidades. Secretaria Nacional de Saneamento Ambiental - SNSA.

Sistema Nacional de Informações sobre Saneamento: Diagnóstico dos Serviços de Água e Esgotos - 2013. Brasília: SNSA/MCIDADES. 182 p. : il. 2015.

Ministério das Cidades. Secretaria Nacional de Saneamento Ambiental - SNSA.

Sistema Nacional de Informações sobre Saneamento: Diagnóstico dos Serviços de Água e Esgotos - 2014. Brasília: SNSA/MCIDADES. 212 p. : il. 2016.

Ministério das Cidades. Secretaria Nacional de Saneamento Ambiental - SNSA.

Sistema Nacional de Informações sobre Saneamento: Diagnóstico dos Serviços de Água e Esgotos - 2015. Brasília: SNSA/MCIDADES. 212 p. : il. 2017.

. Superintendência de Desenvolvimento do Nordeste. Delimitação do

Semiárido. Brasília: Ministério do Desenvolvimento Regional, 2017.

Estatuto da Cidade. LEI No 10.257, DE 10 DE JULHO DE 2001. Disponível em: <http://www.planalto.gov.br/ccivil/leis/LEIS_2001/L10257.htm>. Acesso em 05 de abril de 2018.

. Ministério das Cidades. Plano Nacional de Saneamento Básico. Brasília: Ministério das Cidades, 2013. Disponível em $<$ http://www.cidades.gov.br/images/stories/ArquivosSNSA/Arquivos_PDF/plansab_06-122013.pdf>. Acesso em 05 de março de 2018.

Ministério das Cidades. Secretaria Nacional de Saneamento Ambiental - SNSA. Sistema Nacional de Informações sobre Saneamento: Diagnóstico dos Serviços de Água e Esgotos - 2016. Brasília: SNSA/MCIDADES. 218 p. : il. 2018.

- Ministério do Desenvolvimento Regional. Secretaria Nacional de Saneamento SNS. Sistema Nacional de Informações sobre Saneamento: Diagnóstico dos Serviços de Água e Esgotos - 2017. Brasília: SNS/MDR. 226 p.: il. 2019. 
Ministério do Desenvolvimento Regional. Secretaria Nacional de Saneamento - SNS.

Sistema Nacional de Informações sobre Saneamento: $24^{\circ}$ Diagnóstico dos Serviços de Água e Esgotos - 2018. Brasília: SNS/MDR.180 p.: il. 2019.

BRITTO, A. L. N. P., FORMIGA-JOHNSSON, R. M. Mudanças climáticas, saneamento básico e governança da água na Região Metropolitana do Rio de Janeiro. In: V Encontro Nacional da ANPPAS - Associação Nacional de Pós Graduação e Pesquisa em Ambiente e Sociedade, Florianópolis, 2010.

BRULLE, R. J., et al. Shifting public opinion on climate change: An empirical assessment of factors influencing concern over climate change in the U.S., 2002-2010. Climatic Change, 114, 169-188. 2002.

CABRAL, M. O papel da floresta nos cursos d'água. Soluções baseadas na natureza. Dez. $2017 . \quad$ Disponível em: <http://bibliotecadigital.fgv.br/ojs/index.php/p22on/article/download/73689/70773>. Acessado em 16 de fevereiro de 2020.

CALOW, R., BONSOR, H., JONES L., O'MEALly, S., MACDONALD, A., KAUR, N. Climate change, water resources and WASH: a scoping study. London, UK: ODI. 2011.

CAMPBELL, B.M; et al. Urgent action to combat climate change and its impacts (SDG 13): transforming agriculture and food systems. Curr Opin Environ Sustainability, 34, p.g. 13-20. 2018.

CAMPOS, L. M. de S. et al. Relatório de sustentabilidade: perfil das organizações brasileiras e estrangeiras segundo o padrão da Global Reporting Initiative. Gest. Prod., São Carlos, v. 20, n. 4, p. 913-926, 2013 . $\quad$ Disponível em $<$ http://www.scielo.br/scielo.php?script=sci_arttext\&pid=S0104530X2013000400011\&lng=en\&nrm=iso>. Acessado em 12 de fevereiro de 2020. 
CARLOMAGNO, C. et al. Como criar e classificar categorias para fazer análise de conteúdo: uma questão metodológica. Revista Eletrônica de Ciência Política. vol 7, n. 1, 2016.

COSTA, A. M. Saúde pública e saneamento: resistências e possibilidades intersetoriais no contexto da Lei Nacional do Saneamento Básico. IN: CORDEIRO, B. S. (coord.). Lei Nacional de Saneamento Básico: perspectivas para as políticas e a gestão dos serviços públicos. Brasília: Ministério das Cidades. v II, cap 11, p. 345-356. 2009

COSTA DOS SANTOS, C. A.; MANZI, A. O. Eventos extremos de precipitação no estado do Ceará e suas relações com a temperatura dos oceanos tropicais. Rev. bras. meteorol., São Paulo, v. 26, n. 1, p. 157-165, Mar. 2011. Disponível em $<$ http://www.scielo.br/scielo.php?script=sci_arttext\&pid=S0102$7862011000100014 \& \operatorname{lng}=e n \& n r m=i s o>$. Acessado em 03 de fevereiro de 2020.

COUTINHO, A. C. Análise dos instrumentos da política nacional de recursos hídricos e sua aplicação no estado do Ceará. 2010. 134 f. Monografia (Graduação em Direito) Faculdade de Direito, Universidade Federal do Ceará, Fortaleza, 2010.

DIAZ, P., YEH, D.. Adaptation to Climate Change for Water Utilities. Water Reclamation and Sustainability, 19-56. 2014.

LIMA, A. J. R. As percepções de diferentes atores da gestão de recursos hídricos na proposta de construção de um sistema de monitoramento da governança das águas. 2018. 1 recurso online (240 p.). Tese (doutorado) - Universidade Estadual de Campinas, Instituto de Geociências, Campinas, SP. Disponível em: <http://www.repositorio.unicamp.br/handle/REPOSIP/331339>. Acessado em 20 de fevereiro de 2020.

DE MORAIS, N. L. Capacidade adaptativa específica do município de São Paulo às mudanças climáticas: uma análise a partir do mapeamento das áreas de risco, sistema de alerta e planos de contingência de Defesa Civil. 2019. Dissertação (Mestrado em 
Ambiente, Saúde e Sustentabilidade) - Faculdade de Saúde Pública, Universidade de São Paulo, São Paulo, 2019.

DEMSKI, C. et al. Experience of extreme weather affects climate change mitigation and adaptation responses. Climatic Change 140, 149-164 (2017).

DERYUGINA, T. How do people upyear? The effects of local weather fluctuations on beliefs about global warming. Clim Chang 118(2):397-416. 2013.

DI GIUliO, G. M. et al. Plano Nacional de Adaptação à Mudança do Clima: possibilidades e desafios. Jornal da Ciência, 5520, 2016.

Mudanças climáticas, riscos e adaptação na megacidade de São

Paulo, Brasil. Sustentabilidade em Debate - Brasília, v. 8, n.2, p. 75-87, 2017

Mídia brasileira e mudanças climáticas: uma análise sobre tendências da cobertura jornalística, abordagens e critérios de noticiabilidade. Desenvolvimento e Meio Ambiente, [S.1.], v. 40, abr. 2017. Disponível em: <https://revistas.ufpr.br/made/article/view/49002>. Acessado em 23 de junho de 2018.

Adaptação climática: fronteiras do conhecimento para pensar o contexto brasileiro. Estudos Avançados, 30(88), 25-41, 2016. Disponível em $<$ http://www.scielo.br/scielo.php?script=sci_arttext\&pid=S0103$40142016000300025 \& \operatorname{lng}=$ en\&nrm=iso $>$. Acessado em 25 de novembro de 2019.

Extreme Events, Climate Change and Adaptation in the State of Sao Paulo. Ambient. soc., São Paulo, v. 22, e02771, 2019 . Disponível em $<$ http://www.scielo.br/scielo.php?script=sci_arttext\&pid=S1414753X2019000100329\&lng=en\&nrm=iso>. Acessado em 19 de fevereiro de 2020.

DUARTE, R. Entrevistas em pesquisas qualitativas. Educ. rev. [online]. n.24, pp.213-225. 2004. 
O painel brasileiro de mudanças climáticas na interface entre ciência e políticas públicas: identidades, geopolítica e concepções epistemológica. Sociologias, v. 21, n. 51, p. XXX, 2019.

EAKIN, H. et al. Differentiating capacities as a means to sustainable climate change adaptation. Global Environmental Change, v.27, p.1-8, 2014.

FERREIRA, J. G. et al. A água da transposição do Velho Chico como solução para seca do Nordeste. Anais II CONIDIS. V. 1, 2017.

GALVÃO JUNIOR, A. C.; TUROLLA, F. A.; PAGANINI, W. S. Viabilidade da regulação subnacional dos serviços de abastecimento de água e esgotamento sanitário sob a Lei 11.445/2007. Eng. Sanit. Ambient., São Paulo, v. 13, n. 2, p. 134-143, 2008.

GALVÃO JUNIOR, A.C. Desafios para a universalização dos serviços de água e esgoto no Brasil. Rev Panam Salud Publica. 25(6):548-56. 2009.

GRIMM, A.M.; FERRAZ, S.E.T; CARDOSO, A. de O. Influência de El Niño sobre a chuva no Nordeste Brasileiro. X Congresso Brasileiro de Meteorologia e VII Congresso da FLISMET, Brasília, 1998.

GUERREIRO, M. L. F. B. Dessalinização para produção de água potável: perspectivas para Portugal. 80 f. Dissertação (Mestrado Integrado em Engenharia Civil). Universidade do Porto, $\quad 2009 . \quad$ Portugal, Disponível em: <https://repositorioaberto.up.pt/bitstream/10216/60336/1/000136611.pdf>. Acessado em 10 de janeiro de 2020.

HAUFF, S. N. Representatividade do Sistema Nacional de Unidades de Conservação na Caatinga. Brasília: PNUD - Programa das Nações Unidas para o Desenvolvimento. Projeto BRA/00/021. 2010. $110 \mathrm{p}$ 
HELLER, L. et al. Identificando correntes teóricas de planejamento: uma avaliação do Plano Nacional de Saneamento Básico (Plansab). Rev. Adm. Pública, Rio de Janeiro, v. 47, n. 3, p. 601-622, Junho, $2013 . \quad$ Disponível em $<$ http://www.scielo.br/scielo.php?script=sci_arttext\&pid=S0034$76122013000300004 \& \operatorname{lng}=e n \& n r m=i s o>$. Acessado em 09 de fevereiro 2020.

HERBER, M. W. Underlying concerns in land-use conflicts: the role of place-identity in risk perception. Environmental Science and Policy, Waltham, v. 7, n. 2, p. 109-116, 2004.

HINE, D. W. et al. Identifying climate change interpretive communities in a large Australian sample. Journal of Environmental Psychology, 36, 229-239. 2003.

HIRATA, R., SUHOGUSOFF, A. V., MARCELliNI, S. S., VILLAR, P. C., MARCELLINI, L. A revolução silenciosa das águas subterrâneas no Brasil: uma análise da importância do recurso e os riscos pela falta de saneamento. São Paulo. Instituto Trata Brasil. 2019. Disponível em http://www.tratabrasil.org.br/images/estudos/itb/aguas-subterraneas-esaneamento-basico/Estudo_aguas_subterraneas_FINAL.pdf. Acessado em 07 de fevereiro de 2020.

IBGE. CENSO DEMOGRÁFICO 2010. Características da população e dos domicílios: resultados do universo. Rio de Janeiro: IBGE, 2011. Disponível em: <http://www.ibge.gov.br/home/estatistica/populacao/censo2010/caracteristicas_da_populacao / resultados_do_universo.pdf>. Acessado em 30 de janeiro de 2020.

- Diretoria de Pesquisas, Coordenação de População e Indicadores Sociais. Estimativas da população residente com data de referência $1^{\circ}$ de julho de 2019. Disponível em <https://www.ibge.gov.br/estatisticas/sociais/populacao/9103-estimativas-depopulacao.html?=\&t=o-que-e $>$. Acessado em 29 de novembro de 2019.

IBGE - cidades @. Disponível em: <http://www.ibge.gov.br/cidadesat/default.php>. Acessado em 29 de janeiro de 2020. 
IPCC. Climate Change 2007: impacts, adaptation and vulnerability: contribution of Working Group II to the fourth assessment report of the Intergovernmental Panel. Cambridge, UK. 2007.

IPCC Factsheet. What is the IPCC? Disponível em <www.ipcc.ch1http://www.ipcc.ch/pdf/tor/TOR_Bureau.pdf>. Acessado em 25 de janeiro de 2020.

Climate Change 2014 - Synthesis Report. Contribution of Working Groups I, II and III to the Fifth Assessment Report of Intergovernmental Panel on Climate Change. Geneva. 2014.

Summary for Policymakers: Global Warming of $\mathbf{1 . 5}^{\circ} \mathrm{C}$. Geneva, Switerzeland, 2018.

History - IPCC. Disponível em <https://www.ipcc.ch/about/history/>. Acessado em 25 de janeiro de 2020.

KONISKY, D.M. et al. Extreme weather events and climate change concern. Climatic Change 134, 533-547 (2016). https://doi.org/10.1007/s10584-015-1555-3

LEITE, D. A. Gerenciamento de discursos hídricos: a comunicação da crise de abastecimento de água na Região Metropolitana de São Paulo (2014-2015). 2018. 1 recurso online (165 p.). Dissertação (mestrado) - Universidade Estadual de Campinas, Instituto de Geociências, Campinas, SP.

LEONETI, A. B. P. et al. Saneamento básico no Brasil: considerações sobre investimentos e sustentabilidade para o século XXI. Universidade de São Paulo, Revista de Administração Pública, 2011. 
LINDOSO, et al. Desenvolvimento Sustentável, Adaptação e Vulnerabilidade à Mudança Climática no Semiárido Nordestino: Um Estudo de Caso no Sertão do São Francisco. Revista Econômica do Nordeste. Fortaleza, v. 44, n. 1, p.301-332, jun. 2013.

LOURENÇO, G. M. Recados da Novas Demografia Brasileira. Vitrine da Conjuntura, Curitiba, v. 11, ed. 7, Setembro 2018.

JACOBI, P. R.; CIBIM, J.; LEAO, R. S. Crise hídrica na Macrometrópole Paulista e respostas da sociedade civil. Estudos Avançados, São Paulo, v.29, n.84, p.27-42, ago. 2015b. Disponível em: <http://www.scielo.br/scielo.php?script=sci_arttext\&pid=S010340142015000200027\&lng=en\&nrm=iso>. Acesso em: 24 jul. 2018.

MALHEIROS, T. F.; PROTA, M. G.; PEREZ RINCON, M. A. Participação comunitária e implementação dos instrumentos de gestão da água em bacias hidrográficas. Rev. Ambient. Água, Taubaté , v. 8, n. 1, p. 98-118, Abr 2013 . Disponível em $<$ http://www.scielo.br/scielo.php?script=sci_arttext\&pid=S1980-

993X2013000100008\&lng=en\&nrm=iso>. Acessado em 17 de maio de 2020.

MARENGO, J. A. et al. Variabilidade e mudanças climáticas no semiárido brasileiro. In: Medeiros SS, Gheyi HR, Galvão CO, Paz VPS, organizadores. Recursos hídricos em regiões áridas e semiáridas Campina Grande: Instituto Nacional do Semiárido; p.384-422. 2011.

MARENGO, J. A seca e a crise hídrica de 2014-2015 em São Paulo. Revista USP 106, 3144, 2015.

MARENGO, J. et al. A seca de 2012-15 no semiárido do Nordeste do Brasil no contexto histórico. Climanálise, 2016.2 Disponível em: $<$ http://climanalise.cptec.inpe.br/ rclimanl/revista/pdf/30anos/marenFgoetal.pdf $>$. Acesso 25 de janeiro de 2020.

MARICATO, E. O impasse da política urbana no Brasil. Petrópolis, RJ: Vozes, 2011.

MARTINS, R. M. Titularidade do serviço de saneamento básico. In. Revista de Direito Administrativo, vol. 249, set/dez, 2008. 
MARTINS, E. S. R. et al. A seca de 2012 - 2015 no Nordeste e seus impactos. Parc. Estrat. Ed. Especial, Brasília, v. 20, n. 41, p. 107-128, 2015.

Medidas de Mitigação e Adaptação às Mudanças Climáticas Câmara dos Deputados, Comissão de Meio Ambiente e Desenvolvimento Sustentável. Brasília. Desastres Naturais, Vulnerabilidade e Adaptação no Brasil: INCT para Mudanças Climáticas Fase 2 [...]. Brasília: Jose A. Marengo, 2019. 10 p. Tema: Medidas de Mitigação e Adaptação às Mudanças Climáticas. 2019.

MELO, A.J.M.; GALVÃO JUNIOR, A.C. Regulação e universalização da prestação dos serviços de abastecimento de água. Paranoá, Brasília, no 10, p. 49-58, 2013.

MELO, M. et al. Migrantes Nordestinos na Região Metropolitana de São Paulo: características socioeconômicas e distribuição espacial. 2019. Disponível em <https://journals.openedition.org/confins/19451>. Acessado em 10 de fevereiro de 2020.

MENDES, B. V. Desertificação do Semiárido. In: Documento sobre Desertificação no Nordeste. Brasília: SEMA/ MMA/ SUDENE, 1986.

MILHORANCE, C. et al. O Desafio da Integração de Políticas Públicas para a Adaptação às Mudanças Climáticas no Semiárido Brasileiro. Revista Brasileira de Climatologia, v. 24, p. 165-185, 2019.

MINISTÉRIO DA FAZENDA. Brasil. Documento-base para discussão da Estratégia do Brasil para o Fundo Verde do Clima - GCF. 2017. Disponível em: <http://www.fazenda.gov.br/assuntos/atuacao-internacional/fundo-verde-doclima/arquivos/documento-base-para-discussao_estrategia-do-brasil-para-o-gcf_08_11.pdf>. Acessado em 08 abr. 2018.

MMA - Ministério do Meio Ambiente; TNC. Mapa das Unidades de Conservação e Terras Indígenas do Bioma Caatinga. Org. Shirley Hauff. Coronário : Brasília. 2 p. 2008. 
MONTEBELlo, N. et al. Retirantes flagelados no Ceará-da-seca:. Conhecer: Debate Entre O Público E O Privado. 8(21), 60-77. 2018.

MORO, M. F. et al. Vegetação, unidades fitoecológicas e diversidade paisagística do estado do Ceará. Rodriguésia, Rio de Janeiro , v. 66, n. 3, p. 717-743, Sept. 2015. Disponível em $\quad<$ http://www.scielo.br/scielo.php?script=sci_arttext\&pid=S217578602015000300717\&lng=en\&nrm=iso>. Acessado em 31 Jan. 2020.

NALON, M. A; SINSIGALLI, P. A DE ALMEIDA; SOUSA JÚNIOR, W. C. Cenários para os serviços ecossistêmicos de São Paulo com as mudanças climáticas. In: JACOBI, P. R; TRANI, E (2019). Planejando o Futuro Hoje: ODS 13, Adaptação e Mudanças Climáticas em São Paulo. P 90-93.

NEDER, E. A. Potencial de adaptação dos municípios paulistas aos efeitos das mudanças climáticas: aplicação do índice de adaptação urbana no Estado de São Paulo. 2019. Dissertação (Mestrado em Ambiente, Saúde e Sustentabilidade) - Faculdade de Saúde Pública, Universidade de São Paulo, São Paulo, 2019. doi:10.11606/D.6.2019.tde-26082019122652. Acessado em 30 de janeiro de 2020.

NEVES, F. M. et al. As estratégias de enfrentamento das mudanças climáticas expressas nas políticas públicas federais do Brasil. Desenvolvimento e Meio Ambiente, v. 34, 2015.

NOBRE, C. A. Mudanças climáticas e o Brasil - Contextualização. Parcerias Estratégicas, v.27, p.7-17, 2008.

NOBRE, C. A., YOUNG, A. F., SAldiva, P., MARENGO, J. A., NOBRE, A. D., JR., S. A., et al. Vulnerabilidades das megacidades brasileiras às mudanças climáticas: Região Metropolitana de São Paulo. São Paulo: INPE, 2010

OATES, N. et al. Adaptation to climate change in water, sanitation, and hygiene: Assessing risks, appraising options in Africa. London: Overseas Development Institute. 2014. Disponível em https://www.odi.org/sites/odi.org.uk/files/odi-assets/publicationsopinion-files/8858.pdf acessado em 07 de fevereiro de 2020. 
OBERMAIER, M. et al. A abordagem brasileira sobre vulnerabilidades em áreas urbanas: uma análise crítica. In: Anais do IV SIC, João Pessoa, 2011.

Mudança climática e adaptação no Brasil: uma análise crítica. Estud. av. São Paulo, v. 27, n. 78, p. 155-176, 2013. Disponível em $<$ http://www.scielo.br/scielo.php?script=sci_arttext\&pid=S0103$40142013000200011 \& \operatorname{lng}=e n \& n r m=i s o>$. Acessado em 25 de novembro de 2019.

OFWAT. Balance of risk: Risk and reward across the water and sewerage value chain. 2015. Disponível em: <https://www.ofwat.gov.uk/publication/balance-of-risk-risk-andreward-across-the-water-and-sewerage-value-chain/>. Acessado em 15 de janeiro de 2020.

OLIVEIRA, K. F. et al. Motivos para migração no Brasil e retorno ao nordeste: padrões etários, por sexo e origem/destino. São Paulo Perspec., São Paulo, v. 19, n. 4, p. 134-143, Dez. 2005. Disponível em <http://www.scielo.br/scielo.php?script=sci_arttext\&pid=S0102$88392005000400009 \& \operatorname{lng}=$ en\&nrm=iso > . Acessado em 20 de fevereiro de 2020.

PAGANINI, W. da S. A identidade de um rio de contrastes: o Tietê e seus múltiplos usos. [S.1: s.n.], 2007.

PAINEL SANEAMENTO BRASIL. Instituto Trata Brasil, 2020. Disponível em <https://www.painelsaneamento.org.br> . Acessado em 10 de janeiro de 2020.

PETIT, J.R. et al. 1999. Climate and atmospheric history of the past 420,000 years from the Vostok ice core, Antarctica. Nature, 399:429-436

PEREIRA, R. G. de M. Proposta metodológica para avaliação da gestão municipal de saneamento básico. 2019. 102 f. Dissertação (Mestrado em Engenharia Civil) - Universidade Federal de Viçosa, Viçosa. 2019. 
PMBC. Base científica das mudanças climáticas. Contribuição do Grupo de Trabalho 1 do Painel Brasileiro de Mudanças Climáticas ao Primeiro Relatório da Avaliação Nacional sobre Mudanças Climáticas [T. Ambrizzi, \& M. Araújo, (Orgs.)]. Rio de Janeiro: COPPE, Universidade Federal do Rio de Janeiro. 2014a.

Impactos, vulnerabilidades e adaptação às mudanças climáticas. Contribuição do Grupo de Trabalho 2 do Painel Brasileiro de Mudanças Climáticas ao Primeiro Relatório da Avaliação Nacional sobre Mudanças Climáticas [E. D. Assad, \& A. R. Magalhães (Orgs.)]. Rio de Janeiro: COPPE, Universidade Federal do Rio de Janeiro. 2014b.

Mitigação das mudanças climáticas. Contribuição do Grupo de Trabalho 3 do Painel Brasileiro de Mudanças Climáticas ao Primeiro Relatório da Avaliação. 2014c.

PINHEIRO, J. Q. et al. Mudanças climáticas globais: Viés de percepção, tempo e espaço. Estud. psicol. (Natal), Natal, v. 23, n. 3, p. 282-292, set. 2018. Disponível em $<$ http://pepsic.bvsalud.org/scielo.php?script=sci_arttext\&pid=S1413294X2018000300008\&lng=pt\&nrm=iso >. acessado em 26 de novembro de 2019.

PINHO, A. et al. Gestão e controle de perdas de águas. Trabalho de Conclusão de Curso (Engenharia Civil). UNIFAAT, Centro Universitário Engenharia Civil, Atibaia, 2018.

PRODES - Coordenação-Geral de Observação da Terra. [online] disponível em: <http://www.obt.inpe.br/OBT/assuntos/programas/amazonia/prodes>. Acessado em 19 de fevereiro de 2020.

RANGER, N. Topic guide: adaptation - decision-making under uncertainty. Evidence on Demand. 2013.

REI, F. C. F. et al. Acordo de Paris: Reflexões e Desafios Para o Regime Internacional de Mudanças Climáticas. Veredas do Direito: Direito Ambiental e Desenvolvimento Sustentável, Belo Horizonte, v. 14, n. 29, p. 81-99, out. 2017. ISSN 21798699. Disponível 
em: <http://www.domhelder.edu.br/revista/index.php/veredas/article/view/996>. Acessado em 19 de fevereiro de 2020.

RIBEIRO, W. C. Impactos das mudanças climáticas em cidades no Brasil. Parcerias Estratégicas, v.27, p.297-321, 2008.

RIBEIRO, L. C. L. J.; ANDRADE, J. G. P.; ZAMBON, A. G. Cultivo de espécies hortícolas para a segurança alimentar e nutricional de famílias assentadas em Terenos/MS. Revista Ibero-Americana de Ciências Ambientais, v.8, n.2, p.155-166, 2017.

RODRIGUES FILHO, S. et al. O clima em transe: políticas de mitigação e adaptação no Brasil. Revista Brasileira de Climatologia, v. 19, p. 74-90, 2016.

ROLIM, G. de S.; CAMARGO, M. B. P. de; LANIA, D. G.; MORAES, J. F. L. de. Classificação climática de Köppen e de Thornthwaite e sua aplicabilidade na determinação de zonas agroclimáticas para o Estado de São Paulo. Bragantia, v.66, p.711-720, 2007.

ROSA, E. A. The logical structure of the social amplification of risk framework (SARF): Metatheoretical foundations and policy implications. In N. F. Pidgeon, R. E. Kasperson, \& P. Slovic (Eds.), The social amplification of risk (pp. 47-79). Cambridge, U.K.: Cambridge University Press, 2003.

SÃO PAULO. Companhia de Saneamento Básico do Estado de São Paulo (Sabesp). Crise Hídrica, Estratégia e Soluções da Sabesp. São Paulo, 2015.

SANTOS, M. et al. Território, Globalização e Fragmentação. Hucitec: São Paulo. 1994.

SCANTIMBURGO, André Luis. O Banco Mundial e a política nacional de recursos hídricos. São Paulo: Cultura Acadêmica, 2013. (Coleção PROPG Digital - UNESP). ISBN 9788579834882. Disponível em: <http://hdl.handle.net/11449/109307>. Acessado em 18 de maio de 2020. 
SCHAPIRO, M. G. et al. Conflito de Interesses nas Empresas Estatais: Uma análise dos casos Eletrobrás e Sabesp. Rev. Direito Práx., Rio de Janeiro, 2018. v. 9, n. 3, p. 14241461.

Vulnerabilidade e mudanças climáticas: análise socioambiental em uma mesorregião da Amazônia. Rev. Ambient. Água [online]. 2017, vol.12, n.5, pp.842854. ISSN 1980-993X.

SETZER, J. Atlas Climático e Ecológico do Estado de São Paulo. Comissão Interestadual da Bacia Paraná-Uruguai, 61p. 1966.

SAIANI, C. C. S..; TONETO JUNIOR, R. Evolução do acesso a serviços de saneamento básico no Brasil (1970 a 2004). Econ. soc., Campinas , v. 19, n. 1, p. 79-106, Abr. 2010. Disponível em $\quad<$ http://www.scielo.br/scielo.php?script=sci_arttext\&pid=S010406182010000100004\&lng=en\&nrm=iso>. Acessado em 19 de maio de 2020.

SIEGEL, S. Faça-se a água: a solução de Israel para um mundo com sede de água = Let there be water: Israel's solutions for water-starved world. São Paulo: EDUC, 2017.

SHI, J. et al. Knowledge as a driver of public perceptions about climate change reassessed. Nature Climate Change, 6, 759-762. 2016.

SILVA, V. A et al. Saneamento básico e seus impactos na mortalidade infantil e no desenvolvimento econômico da região Nordeste. Scientia Plena, [s.l.], v. 13, n. 10, p.1-7, 30. Associacao Sergipana de Ciencia. 2017.

SILVEIRA, R. N. C. M. et al. Efeitos da Seca em Perímetros Irrigados no Semiárido Brasileiro. Anuário do Instituto de Geociências UFRJ, Rio de Janeiro, v. 41, ed. 2, p. 268$275,2018$.

SMITH, H. C. Accessing Water and Sanitation Services in a Changing Environment: Insights into Vulnerability in Peri-Urban Bangalore. [S.1.: s.n.], 2015. 85 p. Disponível 
em: <https://www.uea.ac.uk/documents/9255683/11805700/MSc+Dissertation++H+Crichton-Smith+-+submitted+version.pdf/5a86e9bc-d3ad-4a3b-ab50-c221d117a878>. Acessado em 03 de abril de 2018.

SJÖBERG, L. The methodology of risk perception research. Quality and Quantity, 34(4), 407-418. 2000.

StallingS, A. R. Media Discourse and the Social Construction of Risk, Social Problems, Volume 37, Issue 1, pg. 80-95. 1990.

STENGERS, I. No tempo das catástrofes: resistir à barbárie que se aproxima. São Paulo: Cosac Naify, 2015

STEYL, G. D. I. Review of coastal-area aquifers in Africa. Hydrogeol J 18(1):217-225, 2010 .

TARGINO, T. R. et al. A percepção humana sobre meio ambiente e mudanças climáticas um estudo de valoração para a região de Anápolis 2016 - 2017. Anais do Congresso de Ensino, Pesquisa e Extensão da UEG (CEPE) (ISSN 2447-8687), v. 4, 2017.

TAVARES, V. C. et al. Desertificação, mudanças climáticas e secas no semiárido brasileiro: uma revisão bibliográfica. Geosul, Florianópolis, v. 34, n. 70, p. 385-405, mar. 2019

TORRES, R. R. Qual é o conhecimento disponível hoje e quais informações ainda faltam para São Paulo. Dezembro/2016. In: DI GIULIO, G. M. et al. Relatório Técnico-Científico Workshop Mudanças climáticas e o processo decisório na megacidade de São Paulo: análise das discussões promovidas, 2016-2017.

TUAN, Y. Topofilia: um estudo da percepção, atitudes e valores do meio ambiente. São Paulo: Difel, 1974. 
UNITED NATIONS DEVELOPMENT PROGRAMME. Human development indices and indicators, 2018 statistical update. New York, NY: United Nations. 2018.

UZZEL, D. The psycho-spatial dimension of global environmental problems. Journal of Environmental Psychology, 20(4), 307-318. 2000.

VAN DER LINDEN, S. Determinants and Measurement of Climate Change Risk Perception, Worry, and Concern. In M.C. Nisbet, M. Schafer, E. Markowitz, S. Ho, S. O'Neill, \& J. Thaker (Eds.), The Oxford Encyclopedia of Climate Change Communication. Oxford University Press, Oxford, UK, 2017. Disponível em $<$ https://ssrn.com/abstract=2953631> Acessado em 28 de fevereiro de 2020.

VON SPERLING, M, M. et al. Nutrientes de esgoto sanitário: utilização e remoção. Rio de Janeiro: ABES, 2009

VIVAS, E., MAIA, R. A gestão de Escassez e secas enquadrando as Alterações climáticas. Revista Recursos Hídricos, Vol. 31, 1, 25-37. 2010.

XAVIER, A. C. et al. Daily gridded meteorological variables in Brazil (1980-2013). Int. J Climatol 36: 2644-2659. 2015

.An update of Xavier, King and Scanlon (2016) daily precipitation gridded data set for the Brazil. In: ANAIS DO SIMPÓSIO BRASILEIRO DE SENSORIAMENTO REMOTO, 2017...Anais eletrônicos... Campinas, GALOÁ, 2018.

YANG, J., ZHU, X., Adapting urban water utilities to climate uncertainties: a case study of Wuhan, PRC. Procedia Engineering, 198, pp.496-510. 2017. 


\section{APÊNDICE A}

\section{ROTEIRO DAS ENTREVISTAS SEMIESTRUTURADAS}

Projeto de Pesquisa: Mudanças climáticas e Acesso à Água e Esgotamento Sanitário Desafios e Oportunidades para os estados do Ceará e São Paulo, Brasil.

Pesquisador: Rubens Amaral Ferreira Filho

Orientadora: Professora Dra. Gabriela Marques Di Giulio

O presente projeto tem como objetivo investigar as percepções de representantes das empresas estaduais de água e esgoto, agências reguladoras de saneamento básico, e Terceiro Setor com foco em água e esgoto sobre os desafios que as mudanças climáticas impõem à oferta destes serviços e possibilidades de ações de adaptação, com foco nos estados de São Paulo e Ceará. Considerando os impactos das mudanças climáticas na sociedade, sob a ótica da infraestrutura urbana, a pesquisa também procura compreender como as intervenções na infraestrutura, como água e esgotamento sanitário, têm sido planejadas em consonância com os cenários climáticos - particularmente considerando a ocorrência dos eventos extremos. 
A pesquisa inclui a realização de entrevistas semiestruturadas baseadas em um roteiro prévio, que contempla informações a serem obtidas sobre quatro temáticas investigadas: 1 . Mudanças climáticas; 2. Riscos na demanda futura por água; 3. Riscos no esgotamento sanitário; 4. Uso de novas tecnologias para água e esgotamento sanitário. As entrevistas semiestruturadas serão realizadas com representantes de operadores estaduais de água e esgoto dos estados de São Paulo e Ceará; representantes de agências reguladores estaduais de São Paulo e Ceará; e ONGs ambientais de São Paulo e Ceará.

A seguir são disponibilizados os aspectos a serem contemplados na realização das entrevistas:

1. Mudanças Climáticas

1.1 - Qual é a percepção do(a) entrevistado(a) sobre as mudanças climáticas? Como o(a) entrevistado(a) encara as ocorrências dos eventos extremos sob a ótica pessoal?

1.2 - Quais são as experiências do profissional durante o exercício da função na empresa/instituição em relação aos eventos extremos? Durante o período do profissional na empresa/instituição, as secas ou precipitações acima do normal são/foram enxergadas como eventos extremos que poderiam ter sido previstos para prevenir impactos à empresa e aos consumidores?

1.3 - Como o(a) entrevistado(a) vê a empresa/instituição pelo qual o(a) mesmo(a) trabalha em relação à concepção das mudanças climáticas? Existe pesquisas ou ações na empresa/instituição para compreender os impactos das mudanças climáticas?

1.4 $\mathrm{O}$ (a) entrevistado(a) acredita que existe riscos para a empresa/instituição em relação as mudanças climáticas?

2. Riscos na demanda futura por água

2.1 - O(a) entrevistado(a) entende que há impacto das mudanças climáticas no abastecimento de água para a população? Se sim, como? Se não, por quê?

2.2 - Como o(a) entrevistado(a) avalia a demanda futura por água para todos os setores, mas sobretudo para o abastecimento à população? É um risco a ser avaliado e considerado? 
2.3 - Qual a avaliação do(a) entrevistado(a) sobre as ações previstas ou em curso, por parte da instituição ou empresa que trabalha, para suprir demanda de água no futuro? 2.4 - $\mathrm{O}(\mathrm{a})$ entrevistado(a) reconhece como risco o custo financeiro pela água no futuro?

2.5 - O (a) entrevistado (a) avalia que os eventos extremos ocorridos no estado avaliado foram preponderante para alteração da tarifa dos serviços de água e esgotamento sanitário?

2.5 - Em relação ao abastecimento de água, o(a) entrevistado(a) vê outros impactos referentes aos eventos extremos, além do aumento da tarifa, para a sociedade no curto, médio e longo prazo para a sociedade?

3. Riscos nos sistemas de esgotamento sanitário 3.1 - Como o(a) entrevistado(a) enxerga os desafios para expandir redes de coleta de esgoto? As mudanças climáticas também são mais uma barreira para o avanço desta infraestrutura?

3.2 - $\mathrm{O}$ (a) entrevistado(a) entende que as precipitações acima do normal podem ocasionar problemas estruturais para as estações de tratamento de água e esgoto? Se sim, como isso afeta diretamente a população?

3.3 - $\mathrm{O}$ (a) entrevistado(a) entende que os eventos climáticos podem aumentar as chances de impactos à saúde pública, principalmente quando a sociedade já está exposta à ausência da infraestrutura de saneamento básico?

3.4 - O(a) entrevistado entende que há implicações de custos para a sociedade quando os eventos extremos atingem a infraestrutura de esgotamento sanitário?

4. Uso de novas tecnologias para água e esgotamento sanitário:

4.1 - Em locais remotos ou áreas de difícil acesso nas zonas urbanas, o(a) entrevistado(a) entende que é importante pensar em uso de novas tecnologias para levar a infraestrutura de saneamento básico para estas famílias?

4.2 - Como o(a) entrevistado(a) identifica as mudanças climáticas como temática/objeto relevante ao buscar por novas tecnologias de abastecimento de água e coleta e tratamento de esgoto? É um tema relevante para a instituição/empresa pela qual o(a) mesmo trabalha? 
4.3 - Quais são os desafios técnicos em épocas de grandes chuvas e estiagens?

O roteiro das perguntas semiestruturadas está desenhado para todos os atores envolvidos na pesquisa, ou seja, I. as companhias estaduais de saneamento básico dos estados de São Paulo e Ceará; II. as agências estaduais de regulação do saneamento básico de São Paulo e Ceará; e III. as organizações não-governamentais apontadas no projeto dos estados de São Paulo e Ceará. Para obter as respostas de diferentes atores, os temas e subtemas serão usados como norteadores, todavia as abordagens junto aos entrevistados serão distintas respeitando o caráter das instituições estudadas.

São Paulo, 12 de abril de 2019 


\section{USP - FACULDADE DE SAÚDE \\ PÚBLICA DA UNIVERSIDADE DE \\ SÃO PAULO - FSP/USP}

\section{APÊNDICE B}

\section{PARECER CONSUBSTANCIADO DO CEP}

DADOS DO PROJETO DE PESQUISA

Título da Pesquisa: Mudanças climáticas, acesso à água e esgotamento sanitário - desafios e oportunidades para os estados de São Paulo e Ceará

Pesquisador: RUBENS AMARAL FERREIRA FILHO

Área Temática:

Versão: 2

CAAE: 09099418.1.0000.5421

Instituição Proponente: Faculdade de Saúde Pública USP/SP

Patrocinador Principal: Financiamento Próprio

DADOS DO PARECER

Número do Parecer: 3.315 .556

\section{Apresentação do Projeto:}

O projeto tem como objeto a percepção de representantes das empresas estaduais de água e esgoto, agências reguladoras de saneamento básico e do terceiro setor com foco em água e esgoto sobre as mudanças climáticas.

\section{Objetivo da Pesquisa:}

O projeto visa investigar as percepções de representantes das empresas estaduais de água e esgoto, agências reguladoras de saneamento básico e do terceiro setor com foco em água e esgoto sobre os desafios que as mudanças climáticas impõem à oferta desses serviços e possibilidades de ações de adaptação nos estados de São Paulo e Ceará.

\section{Avaliação dos Riscos e Benefícios:}

Riscos: Compreende-se que este tipo de pesquisa oferece riscos mínimos, relacionados à algum desconforto no fornecimento de informações. Portanto, enfatiza-se que a qualquer momento o(a) entrevistado (a) terá direito de recusar-se a participar da pesquisa ou retirar consentimento de uso das informações coletadas sem que ocorra qualquer tipo de prejuízo a sua pessoa, familiares ou quaisquer pessoas próximas. Por fim, na pesquisa proposta, todas as informações coletadas serão sigilosas. 


\section{USP - FACULDADE DE SAÚDE \\ PÚBLICA DA UNIVERSIDADE DE \\ SÃO PAULO - FSP/USP}

Continuação do Parecer: 3.315 .556

Benefícios: Compreende-se que o projeto proposto produzirá resultados sobre os desafios que as mudanças climáticas impõem ao planejamento e prestação dos serviços de água e esgotos no estado de São Paulo e Ceará, indicando possibilidades de ações de adaptação para alcançar maior racionalidade e resiliência nos planejamentos e execuções da infraestrutura urbana. Propõe-se também a elaboração de um sumário executivo em parceria com o Instituto Trata Brasil, com o intuito de gerar uma publicação sobre os desafios do tema central da pesquisa, na perspectiva de ampliar a divulgação científica sobre a temática e aproximar produtores e usuários da informação, buscando -se, assim, oferecer subsídios para tomada de decisão. Os resultados serão apresentados e discutidos na dissertação de mestrado e em artigo, capítulo de livro e trabalho técnico-científico a serem elaborados durante a pesquisa.

\section{Comentários e Considerações sobre a Pesquisa:}

O pesquisador apresentou o roteiro das entrevistas semi-estruturadas.

\section{Considerações sobre os Termos de apresentação obrigatória:}

Aprovado.

\section{Recomendações:}

Aprovado.

\section{Conclusões ou Pendências e Lista de Inadequações:}

Aprovado.

\section{Considerações Finais a critério do CEP:}

Este parecer foi elaborado baseado nos documentos abaixo relacionados:

\begin{tabular}{|c|c|c|c|c|}
\hline Tipo Documento & Arquivo & Postagem & Autor & Situação \\
\hline $\begin{array}{l}\text { Informações Básicas } \\
\text { do Projeto }\end{array}$ & $\begin{array}{l}\text { PB_INFORMAÇÕES_BÁSICAS_DO_P } \\
\text { ROJETO_1268224.pdf }\end{array}$ & $\begin{array}{l}12 / 04 / 2019 \\
15: 12: 41\end{array}$ & & Aceito \\
\hline Outros & $\begin{array}{l}\text { RubensAmaralFerreiraFilhoRoteirodaEnt } \\
\text { revista.pdf }\end{array}$ & $\begin{array}{l}12 / 04 / 2019 \\
15: 12: 16\end{array}$ & $\begin{array}{l}\text { RUBENS AMARAL } \\
\text { FERREIRA FILHO }\end{array}$ & Aceito \\
\hline Folha de Rosto & \begin{tabular}{|l|l|} 
PlataformaBrasilRubens.pdf & \\
\end{tabular} & $\begin{array}{c}11 / 12 / 2018 \\
09: 51: 18\end{array}$ & $\begin{array}{l}\text { RUBENS AMARAL } \\
\text { FERREIRA FILHO }\end{array}$ & Aceito \\
\hline $\begin{array}{l}\text { TCLE / Termos de } \\
\text { Assentimento / }\end{array}$ & $\begin{array}{l}\text { RubensAmaralFerreiraFilhoTermodeCon } \\
\text { sentimento.pdf }\end{array}$ & $\begin{array}{c}30 / 11 / 2018 \\
14: 23: 16\end{array}$ & $\begin{array}{l}\text { RUBENS AMARAL } \\
\text { FERREIRA FILHO }\end{array}$ & Aceito \\
\hline
\end{tabular}




\section{USP - FACULDADE DE SAÚDE PÚBLICA DA UNIVERSIDADE DE SÃO PAULO - FSP/USP}

Continuação do Parecer: 3.315.556

\begin{tabular}{|l|l|c|l|c|}
\hline Justificativa de & RubensAmaralFerreiraFilhoTermodeCon & $30 / 11 / 2018$ & RUBENS AMARAL & Aceito \\
Ausência & sentimento.pdf & $14: 23: 16$ & FERREIRA FILHO & \\
\hline Projeto Detalhado / & ProjetoRubensAmaralFerreiraFilhoFSP & $30 / 11 / 2018$ & RUBENS AMARAL & Aceito \\
Brochura & MESTRADOPROASAS.pdf & $14: 02: 55$ & FERREIRA FILHO & \\
Investigador & & & & \\
\hline
\end{tabular}

Situação do Parecer:

Aprovado

Necessita Apreciação da CONEP:

Não

SAO PAULO, 09 de Maio de 2019

Assinado por:

José Leopoldo Ferreira Antunes (Coordenador(a)) 